\title{
O PLANEJAMENTO E O CONTROLE DA PRODUÇÃO EM ASSOCIAÇÕES DE PEQUENOS AGRICULTORES
}

\author{
JOSÉ VALDEMIR MUENCHEN \\ Contador
}

Orientador: Prof. Dr. EVARISTO MARZABAL NEVES

Dissertação apresentada à Escola Superior de Agricultura "Luiz de Queiroz", da Universidade de São Paulo, para obtenção do título de Mestre em Ciências, Área de Concentração: Economia Aplicada.

PIRACICABA

Estado de São Paulo - Brasil

Julho - 1996 


\section{Dados Internacionais de Catalog ação na Publicação (CIP) DIVISÃO DE BIBLIOTECA E DOCUMENTAÇÃO - Campus "Luiz de Queiroz"/USP}

Muenchen, José Valdemir

O planejamento e controle da produção em associações de pequenos agricultores / José Valdemir Muenchen. - - Piracicaba, 1996.

$109 \mathrm{p}$.

Dissertação (mestrado) - - Escola Superior de Agricultura Luiz de Queiroz, 1996

Bibliografia.

1. AANRA - Rio Grande do Sul 2. Produção agrícola - Planejamento - Rio Grande do Sul 3. Produtor Rural - Associação I. Título 


\section{O PLANEJAMENTO E O CONTROLE DA PRODUÇÃO EM ASSOCIAÇÕES DE PEQUENOS AGRICULTORES}

JOSÉ VALDEMIR MUENCHEN

Aprovada em: 26.08.1996

Comissão julgadora:

Prof. Dr Evaristo Marzabal Neves

ESALQ/USP

Prof. Dr. Pedro Valentim Marques

ESALQ/USP

Prof. Dr. João Luis Cardoso

FEAGRI/UNICAMP

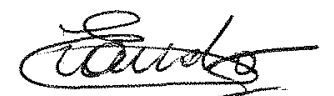

Prof. Dr. Evaristo Marzabal Neves

Orientador 
A minha esposa Gicelda e a meu filho Ricardo, com muito amor, dedico este trabalho. 
AGRADECIMENTOS

A Associação dos Agricultores de Nova Ronda Alta (AANRA) pela acolhida e por todas as informações fornecidas.

Ao professor Dr. Evaristo Marzabal Neves pelo empenho, contribuições e orientações para que este trabalho fosse concluído.

Aos Professores Pedro Valentim Marques, José Vicente Caixeta e João Luis Cardoso pelas valiosas sugestões e observações críticas ao trabalho.

Aos demais professores e funcionários de Departamento de Economia e Sociologia da ESALQ, pela acolhida durante a realização do curso.

A CAPES e à UNIJUÍ pelo apoio recebido para a realização do curso de mestrado. 
SUMÁRIO

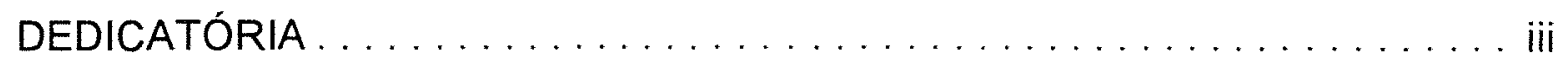

AGRADECIMENTOS $\ldots \ldots \ldots \ldots \ldots \ldots \ldots \ldots \ldots \ldots \ldots \ldots \ldots \ldots \ldots \ldots \ldots$

SUMÁRIO . . . . . . . . . . . . . . . . . . .

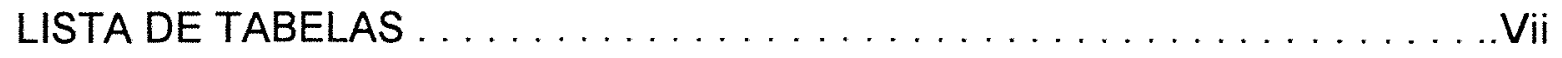

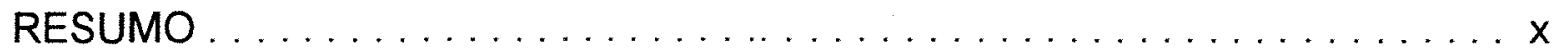

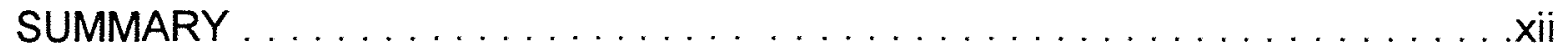

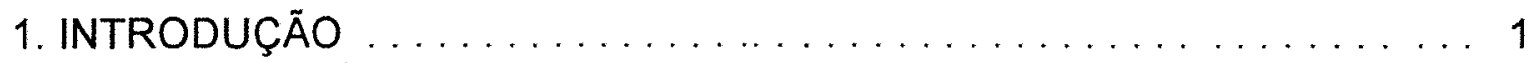

1.1. O Planejamento e o Controle da Produção em

Associações de Produção Coletiva $\ldots \ldots \ldots \ldots \ldots \ldots \ldots \ldots \ldots$

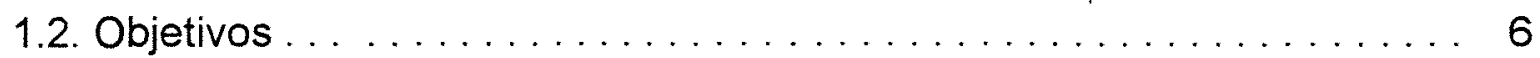

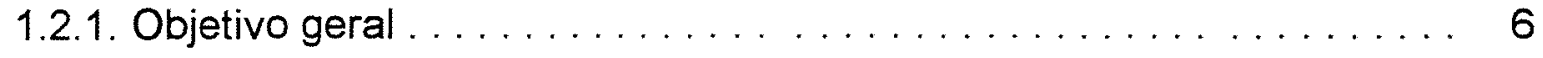

1.2.2. Objetivos específicos $\ldots \ldots \ldots \ldots \ldots \ldots \ldots \ldots \ldots$

2. REVISÃO DE LITERATURA $\ldots \ldots \ldots \ldots \ldots \ldots \ldots \ldots \ldots \ldots \ldots \ldots \ldots \ldots$

2.1. As associações de pequenos agricultores $\ldots \ldots \ldots \ldots \ldots \ldots \ldots$

2.1. O planejamento $\ldots \ldots \ldots \ldots \ldots \ldots \ldots \ldots \ldots \ldots \ldots \ldots \ldots$

2.2. O controle ................................. 13

2.3. Algumas experiências práticas $\ldots \ldots \ldots \ldots \ldots \ldots \ldots \ldots \ldots . \ldots \ldots$

3. METODOLOGIA $\ldots \ldots \ldots \ldots \ldots \ldots \ldots \ldots \ldots \ldots \ldots \ldots \ldots \ldots \ldots \ldots \ldots \ldots \ldots$

3.1. A Associação de Agricultores de Nova Ronda Alta (AANRA) . . . . . . . 27

3.2. Procedimentos Metodológicos . . . . . . . . . . . . . . . . 29 
4. CARACTERIZAÇÃO REGIONAL DA LOCALIZAÇÃO DA ASSOCIAÇÃO.

5. O PCP COMO INSTRUMENTO DE TOMADA DE

DECISÃO NA AANRA

6. UM MODELO DE PCP PARA AS ASSOCIAÇÕES DE

PRODUÇÃO COLETIVA. 59

6.1. O planejamento da produção 60

6.2. O controle da produção . 72

6.3. Controles auxiliares 80

6.3.1. O controle das contas bancárias 80

6.3.2. O controle dos estoques 82

6.3.3. O controle das operações com máquinas 85

6.3.4. O controle da mão-de-obra . 87

6.4. A comparação entre o planejamento e o controle da produção e a apuração do resultado final 88

7. AS CONTRIBUIÇÕES DO MODELO DE PCP PARA AS ASSOCIAÇÕES DE PRODUÇÃO COLETIVA 93

7.1. O modelo de Planejamento e Controle da Produção na Associação dos Agricultores de Nova Ronda Alta 93

7.2. O modelo de PCP e o processo de tomada de decisão nas Associações de produção coletiva . 95

8. CONCLUSÕES 98 BIBLIOGRAFIA .104 


\section{LISTA DE TABELAS}

Tabela 01 - Evolução da população urbana, rural e total no período de 1970 a 1991

Tabela 02 - Evolução do Produto Interno Bruto no período de 1984 a 1993 (US \$ milhões)

Tabela 03 - Evolução do número de unidades de produção agropecuária no período de 1970 a 1985 conforme os extratos de área.

Tabela 04 - Evolução da área total das unidades de produção agropecuária no período de 1970 a 1985 conforme os extratos de área.

Tabela 05 - Evolução da área plantada (ha) e da produção (toneladas) de soja no período de 1970 a 1992.

Tabela 06 - Evolução do rendimento físico da soja no período de 1970 a 1992

Tabela 07 - Evolução da área plantada (ha) e da produção (toneladas) de trigo no período de 1970 a 1990

Tabela 08 - Evolução do rendimento físico (toneladas por hectare) do trigo no período de 1970 a 1990.

Tabela 09 - Evolução da área plantada (ha) e da produção (toneladas) de milho no período de 1970 a 1993.

Tabela 10 - Evolução do rendimento físico (toneladas por hectare) do milho do milho no período de 1970 a 1993. 
Tabela 11 - Evolução do número de vacas ordenhadas e da produção leiteira (1000 litros) no período de 1970 a $1992 . \ldots .43$

Tabela 12 - Evolução da produtividade física (1000 litros/vaca/ano) da atividade leiteira de 1970 a 1992.

Tabela 13 - Evolução do número de bovinos e de suínos no período de 1970 a 1992.

Tabela 14 - Evolução do número de aves e de ovinos no período de 1970 a 1992.

Tabela 15 - Planejamento da produção 63

Tabela 16 - Planejamento do processo técnico de produção para sistemas de cultivo.

Tabela 17 - Planejamento do processo técnico de produção para sistemas de criação. 65

Tabela 18 - Planejamento físico e financeiro da produção para sistemas de cultivo.

Tabela 19 - Planejamento físico e finaceiro da produção para sistemas de criação.

Tabela 20 - Planejamento do fluxo de caixa da Associação 71

Tabela 21 - Controle do livro caixa da Associação . 74

Tabela 22 - Controle do processo técnico de produção para sistemas de cultivo.

Tabela 23 - Controle do processo técnico de produção para sistemas de criação. 
Tabela 24 - Controle físico e financeiro da produção para sistemas de cultivo . . . . . . . . . . . . . . . . . . 79

Tabela 25 - Controle físico e finaceiro da produção para sistemas de criação. 79

Tabela 26 - Controle das contas bancárias da Associação 81

Tabela 27 - Controle dos estoques da Associação 84

Tabela 28 - Controle das operações com máquinas na Associação 86

Tabela 29 - Controle individual da mão-de-obra 87

Tabela 30 - Controle grupal da mão-de-obra. 88

Tabela 31 - Apuração do resultado das atividades 90

Tabela 32 - Apuração do resultado geral da Associação 91 


\title{
O PLANEJAMENTO E O CONTROLE DA PRODUÇÃO EM ASSOCIAÇÕES DE PEQUENOS AGRICULTORES.
}

\author{
Autor: JOSÉ VALDEMIR MUENCHEN \\ Orientador: PROF. DR. EVARISTO MARZABAL NEVES
}

RESUMO

A finalidade do presente estudo é identificar e analisar o modelo de Planejamento e Controle da Produção (PCP) utilizado como suporte ao processo de tomada de decisão da Associação de Agricultores de Nova Ronda Alta (AANRA). A Associação localiza-se no município de Ronda Alta, ao norte do estado do Rio Grande do Sul. Além da identificação e análise do PCP da AANRA, pretende-se, também, a partir dos dados coletados, desenvolver um modelo apropriado. Os instrumentos de Planejamento e de Controle da Produção (PCP), desenvolvidos a partir dos dados da Associação, podem, também, ser utilizados pelas demais associações de produção coletiva.

Os dados utilizados neste trabalho foram obtidos através de entrevistas diretas com a direção da Associação. Por outro lado, também levouse em consideração a coleta de dados e informações obtidas junto aos demais associados, de tal forma que o universo da pesquisa compreende os sócios da Associação. O levantamento dos dados ocorreu durante o ano de 1994. Como procedimento metodológico de coleta de dados, bem como, técnica de captação da realidade das associações, usou-se a técnica da pesquisa-participante. 
O modelo de planejamento e de controle da produção procura produzir um conjunto de informações acerca da unidade de produção, bem como sobre as suas atividades, com vistas a um eficiente, eficaz e racional processo de tomada de decisão. Assim, o modelo tem como principal característica a organização de toda a documentação e das informações sobre as diferentes atividades desenvolvidas na unidade, a partir de um enfoque ex-ante (planejamento) e ex-post (controle).

Para a adoção do modelo, por parte das associações de produção coletiva, devem ser levadas em consideração uma série de dificuldades e de limites que os agricultores e as próprias associações apresentam. Estas dificuldades e limites relacionam-se principalmente aos hábitos, ao conhecimento, às questões sócio-culturais, entre outros. Estas questões devem, internamente na associação, ser bem trabalhadas para que o modelo possa produzir as informações necessárias no processo decisório.

Conclui-se que 0 processo de gerenciamento das associações, baseado em dados e informações produzidos pelos seus próprios processos de PCP, adotado e executado pelos próprios envolvidos, viabiliza o processo de produção do conjunto da associação. Isto significa dizer, em outros termos, que a própria eficiência e eficácia da associação depende, fundamentalmente, da eficiência e da eficácia deste sistema, na medida em que ele viabiliza um aumento da produtividade $e$ da racionalidade no uso dos recursos e dos fatores de produção necessários para a execução das atividades. 
THE PRODUCTION PLANNING AND CONTROL IN SMALL FARMERS ASSOCIATION.

\author{
Author: JOSÉ VALDEMIR MUENCHEN \\ Adviser: PROF. Dr. EVARISTO MARZABAL NEVES
}

\title{
SUMMARY
}

The purpose of this study is to identify and to analyze the Production Planning and Control (PCP) model used as support to the process of decisions taking of the Nova Ronda Alta Farmers Association (AANRA). This association in the city of Ronda Alta, in the North of Rio Grande do Sul state, Brazil. Beside the identification and analyze of PCP of AANRA, is intended also, to develop and appropriate model using the collected data. The Production Planing and Control (PCP) instruments, developed using the Association data, can, also, be used by others associations of collective production.

The data utilized in this paper were found through interviews to the Association staff member (directors). On the other side, it was considered the data collection and information obtained among the associated personnel, so the research was extended to all Association members. As methodological procedure of data collection, as well as the reality perception of the association, it was used the participating-research technique.

The model of production planning and control searches to produce a set of information's about the production unit, as well as about its activities, looking toward an efficient, effective and rational decision making 
process. So. The model has as main characteristic the organization of all the documents and data about the different activities developed in the unit based is a "ex-ante" (planning) and "ex-post" (control) focus.

To the use of the model by the association of collective production, it's necessary to think about the various difficulties and limitations that the farmers and the associations present, that are related, specially, to the habits, knowledge, cultural and social questions, among others, these questions have to be well elaborated so that the model may produce the necessary data in the making decision process.

The conclusion is that the management process of the associations, based in the data and information produce by it's own PCP process, used and executed by the personal involved brings, viability to the production process of the whole association. It means that the own efficient and efficacy of this system of the association depends, basically, of the efficient and efficacy of this system, while it brings viability to an enlargement of rationalization and production in the use of production resources and factors necessary to the execution of the activities. 


\section{INTRODUÇÃO}

\subsection{O Planejamento e o Controle da Produção em Associações de Produção Coletiva}

Com a relativa estabilização da economia brasileira, a partir do Plano Real, e com reflexos diretos sobre os problemas enfrentados no setor agrícola, a organização dos pequenos agricultores em associações, quer sejam de produção, quer de comercialização ou de serviços, entre outras, assume a cada dia um papel mais importante para a manutenção destes agricultores no processo produtivo. Estas associações podem ser definidas como entidades que agrupam certo número de agricultores, com interesses comuns, tendo como finalidade resolver os seus problemas de forma coletiva e com o uso de práticas solidárias.

Um dos principais problemas que este tipo de organização vem sofrendo diz respeito à sua gestão interna, uma vez que podem e devem existir interesses conflitantes dentro do grupo. O uso coletivo dos fatores de produção, com o objetivo de alcançar o bem comum, através da racionalização, do aumento da eficiência e da eficácia das ações faz com que, de certa forma, surjam interesses conflitantes.

Na medida em que a associação amplia as possibilidades de escolha dos indivíduos, ela também traz, por outro lado, certas limitações, uma vez que não é o bem estar individual que está em jogo, mas o do conjunto da população. O agricultor, individualmente, apresenta certos hábitos, determinado nivel de cultura e de conhecimento. $\mathrm{Na}$ associação, isto se transforma no coletivo. A correta administração destes problemas, com certeza, determinará o sucesso 
desta forma de organização. Assim, o processo de tomada de decisão na associação passa a ser um elemento importante, uma resposta concreta aos problemas que este tipo de agricultor enfrenta e, por que não dizer, uma resposta à falta de talento empresarial dos agricultores para gerir a terra.

Por outro lado, os aspectos administrativos propriamente ditos não são os únicos que devem ser levados em consideração na administração da associação. Deve-se ter cuidado especial com os aspectos políticos, sociais, econômicos e culturais, pois este conjunto determinará o sucesso do empreendimento associativo. Porém, não se pode negar a importância do processo de tomada de decisão. Questões relacionadas ao planejamento, ao controle, à direção e à organização do processo de produção são de fundamental importância, pois a eficiência destes terá grande influência no conjunto da associação. Observa-se que as associações, bem como a maioria da unidades de produção, principalmente as pequenas propriedades, não se utilizam dos princípios e métodos administrativos. Muitos dos problemas enfrentados por estas unidades produtivas poderiam ser evitados com 0 uso de alguns instrumentos elementares que ajudem na correta tomada de decisão.

Para CORTINA (1992, p.3), "assim como ocorre em outros setores, a rapidez nas mudanças nas tecnologias de produção, bem como nas políticas adotadas pelo governo que afetam direta ou indiretamente o setor agrícola, exige que as decisões dos administradores rurais sejam cada vez mais baseadas em resultados de planejamento. $\mathrm{Na}$ verdade, esses fatos já provocam mudanças na prática de muitos empresários rurais. Estes vêm sentindo a necessidade de tomar decisões baseadas mais em critérios quantitativos e menos em intuição".

O problema que se coloca não é a simples tomada de decisão baseada em resultados de planejamento. $\mathrm{Na}$ prática, um dos principais problemas em relação ao processo de tomada de decisão diz respeito ao sistema de 
informações que é utilizado como suporte no processo de tomada decisão. O que se observa, também em outros setores, mas principalmente no setor agrícola, mais especificamente na pequena agricultura familiar, é a inexistência de informações úteis e confiáveis que possam servir de suporte no processo administrativo.

O que se tem, na verdade, é um conjunto de dados, que se apresentam ao agricultor de forma dispersa e, por isso, de pouca utilidade. Com as dificuldades por que passa o setor agrícola, uma correta gestão das unidades produtivas poderá viabilizar o seu processo produtivo, fazendo com que estas propriedades possam sobreviver às dificuldades enfrentadas. Como os indivíduos das associações podem ter objetivos que entre si são conflitantes, a administração destas organizações assume um papel fundamental. Como suporte a esta administração, um sistema que forneça informações reais e confiáveis é a primeira necessidade que se apresenta ao processo administrativo.

Com o auxilio de diversas entidades, principalmente de Organizações Não Governamentais (ONGs), as associaçōes estão, pouco a pouco, constituindo mecanismos de gestão. Entretanto, no plano da gestão econômico-financeira, no que tange à implantação de princípios e instrumentos adequados às suas necessidades, à sua concepção político-pedagógica e às suas escalas operacionais, situa-se claramente um limite para a consolidação dessas associações, também pela insuficiente formação dos agentes de desenvolvimento nessa área. Como alternativa a estes problemas, surge o Planejamento e o Controle da Produção (PCP) como instrumento que auxilia no processo de gerenciamento das associações. Este processo passa a ser fundamentado em dados e informações, produzidas pela própria associação. Por outro lado, O PCP adotado e executado pelos próprios envolvidos viabiliza o processo de produção do conjunto da associação, ou seja, a própria eficiência e eficácia da associação dependem fundamentalmente deste sistema na medida em 
que ele viabiliża um aumento da produtividade e da racionalidade no uso dos recursos e dos fatores de produção, necessários para a execução das atividades.

O planejamento da produção deve estar voltado para a continuidade da entidade e focalizar o futuro. Constitui a função administrativa que determina, com antecedência, quais os objetivos a serem atingidos e o que deve ser feito para atingi-los, da melhor maneira possível. Por outro lado, o controle é a função administrativa que tem por finalidade medir e corrigir o desempenho para assegurar que o planejamento seja executado da melhor maneira possível. A tarefa de medir o desempenho é verificar se tudo está sendo feito em conformidade com o que foi planejado e organizado enquanto que corrigir o desempenho tem por finalidade identificar os erros ou os desvios, a fim de corrigi-los e evitar a sua repetição.

Segundo CHIAVENATO (1936, p.24), "o Planejamento e o Controle da Produção (PCP) planeja e controla as atividades produtivas da empresa. Se a empresa é produtora de bens e mercadorias, o PCP planeja e controla a produção desses bens ou mercadorias, cuidando das matérias-primas necessárias, da quantidade de mão-de-obra, das máquinas e equipamentos e do estoque de produtos acabados disponiveis no tempo e no espaço para a área de vendas efetuar as entregas aos clientes".

Assim, pode-se prever que, a partir dos objetivos da associação, o PCP planeja e programa a produção e as operações da entidade, bem como as controla adequadamente, para tirar o melhor proveito possível, em termos de eficiência e eficácia.

Para o presente trabalho será estudada a Associação de Agricultores de Nova Ronda Alta (AANRA) que se localiza no município de Ronda Alta, ao norte do estado do Rio Grande do Sul. A associação originou-se de um assentamento de colonos Sem-Terra que, durante o ano de 1981, acamparam na 
localidade gaúcha conhecida como Encruzilhada Natalino, transferindo-se, em 1983, para Ronda Alta. Já em território definitivo, um grupo de 20 famílias fundou a AANRA, com o objetivo de superar as dificuldades enfrentadas pelos pequenos agricultores do Estado.

A associação, atualmente, é formada por cinco familias e dedica-se a atividades ligadas, principalmente, ao cultivo da soja, do milho, à criação de suínos e gado leiteiro. Outras pequenas lavouras de subsistência e a criação de aves também são desenvolvidas, porém, em menor escala. A tecnologia utilizada pelos agricultores no desenvolvimento de suas atividades não exige alto grau de especialização e assemelha-se à tecnologia da maioria das propriedades de médio porte da região e que desenvolvem o mesmo tipo de atividade.

Além da introdução, este trabalho é composto por mais sete partes. A primeira parte constitui-se na revisão de literatura, tendo por finalidade apresentar um quadro teórico a respeito da evolução histórica do sistema associativo. Também são apresentadas algumas definições sobre o planejamento e o controle enquanto etapas do processo administrativo. A segunda apresenta os aspectos metodológicos, como a definição e caracterização da associação estudada, bem como a definição dos procedimentos metodológicos utilizados.

A terceira parte, tem por objetivo apresentar uma caracterização da região em que a Associação se localiza. Esta caracterização procurará apresentar uma situação econômica microrregional, na qual se insere o município de Ronda Alta, bem como a AANRA. Na quarta parte, efetua-se uma análise da situação atual do modelo de PCP utilizado pela associação. Esta análise tem por finalidade verificar os procedimentos adotados pela associação, que dizem respeito ao Planejamento e ao Controle da Produção, a sua validade $e$ utilidade, em termos gerenciais. 
Na quinta parte discute-se um modelo de PCP que possa ser utilizado pela associação bem como por outras associações que apresentem características semelhantes à AANRA. Este modelo, desenvolvido a partir das informações da própria associação, tem por finalidade o melhor gerenciamento, bem como um processo decisório racional, eficaz e eficiente dos recursos e fatores de produção, disponíveis na associação. Na sexta parte discute-se algumas contribuiçoes do modelo proposto para a AANRA bem como para as demais associações de produção coletiva, Por último, apresentam-se as conclusões acerca do Planejamento e Controle da Produção em associações de produção coletiva.

\subsection{Objetivos}

\subsubsection{Objetivo geral}

Identificar e analisar o modelo de Planejamento e Controle da Produção (PCP) utilizado como suporte ao processo de tomada de decisão da Associação de Agricultores de Nova Ronda Alta (AANRA). Além da identificação e análise do PCP da AANRA, pretende-se também, a partir dos dados coletados, desenvolver um modelo de PCP que possa ser utilizado nesta e em outras associações de produção coletiva.

\subsubsection{Objetivos especificos}

a) Estudar o processo de PCP da Associação de Agricultores de Nova Ronda Alta;

b) Desenvolver um modelo de PCP, utilizável pelas associações de produção coletiva;

c) Discutir as contribições do modelo de PCP na Associação de Agricultores de Nova Ronda Alta. 


\section{REVISÃO DE LITERATURA}

Esta parte do trabalho tem por finalidade apresentar um referencial teórico sobre a evolução recente do associativismo, sobre o planejamento e o controle enquanto etapas do processo de tomada de decisão. Este referencial constitui a base teórica, a partir da qual analisar-se-á o processo de planejamento e controle da produção existente na associação. Além desta base teórica, apresentamos, também, algumas experiências na área da administração rural que se utilizam do planejamento e do controle, enquanto instrumentos gerenciais.

\subsection{As associações de pequenos agricultores}

As novas formas de organização dos pequenos agricultores têm por finalidade o enfrentamento e a solução dos problemas que atingem o setor agrícola, principalmente os que atingem a esta parcela de produtores. São as chamadas associações de pequenos agricultores. Segundo MURCIA (1978), as formas associativas de trabalho, no campo, já eram encontradas entre os primitivos povos indígenas da América. Ainda, segundo $\circ$ Autor, as grandes culturas pré-colombianas desconheciam o conceito individualista da posse da terra, o mesmo acontecendo no regime Azteca e nos povos Incas que também conheceram formas de trabalho e produção coletiva.

A partir da metade do século XIX, surge um modelo de cooperação que se espalha, de forma generalizada e indiscriminada, pela América Latina. Esta forma de cooperação trata-se do cooperativismo clássico de ROCHADELE, cujo objetivo central era promover os interesses econômicos comuns dos produtores rurais. Segundo SANDRONI (1989, p.68) "o cooperativismo é a doutrina que tem por objetivo a solução dos problemas sociais por meio da criação de comunidades de cooperação. Essas comunidades seriam formadas por indivíduos livres, que se encarregariam da gestão da produção e 
participariam igualitariamente dos bens produzidos em comum. Sua realização prática prevê a criação de cooperativas de produção, consumo e crédito".

$\mathrm{Na}$ verdade, este modo de cooperação não conseguiu, na maioria dos casos, dar respostas satisfatórias aos complexos problemas da massa de pequenos produtores empobrecidos, o que resultou no surgimento de novas formas associativas de produção, como é o caso das empresas comunitárias campesinas, no âmbito dos processos de reforma agrária, em alguns países da América Latina.

No Brasil, durante o período colonial, já se conheciam formas associativas de organização do trabalho, como é o caso da ajuda mútua, como os mutirões, a troca de serviços, entre outros. $O$ que se percebe é que um tipo de organização conquista, cada vez mais, uma posição de destaque, no campo brasileiro. São as associação de pequenos agricultores.

BASSO (1992), define as assọciaçōes de pequenos agricultores como uma entidade que agrupa um certo número de agricultores, com interesses comuns, tendo como finalidade resolver os seus problemas coletivos, através de práticas solidárias. Estes problemas podem ser de ordem econômica, política e social.

Ainda, segundo BASSO (1992), podem ser destacados três movimentos históricos que proporcionaram, no Brasil, o surgimento das associações. A partir destes movimentos, iniciou-se um processo de multiplicação de associações, no campo. O primeiro movimento ocorre por volta de 1950, no seio das lutas dos camponeses nordestinos, contra os grandes proprietários e usineiros. Como estratégia de luta, os camponeses construiram as ligas camponesas e também se organizaram, através de associações, como forma de se contraporem ao processo de expulsão da terra e da exploração do trabalho.

Segundo MEDEIROS (1989), essas associações destinaramse aos camponeses que, de alguma forma, tinham acesso à terra e cuja luta se voltava, principalmente, contra os despejos, pelo aumento da renda, entre outros. 
Como se observa, estas primeiras associações tinham como finalidade a superação de dois problemas: um de ordem política, relacionado com a ameaça de expulsão das terras, e outro, de ordem econômica, que se refere à organização da produção e à obtenção de renda para a sua sobrevivência..

Um segundo movimento histórico apontado por BASSO (1992), que contribuiu para o surgimento de associações de agricultores, foi proporcionado pelo próprio Estado, em cooperação com organismos internacionais. Esse movimento ocorre na segunda metade da década 60 e se prolonga na década de 70. Trata-se do Programa de Desenvolvimento Comunitário (PDC) e, depois, os Programas de Desenvolvimento Rural Integrados (PRDIs). Os Programas de Desenvolvimento Comunitário tinham como objetivo a participação popular, como forma de viabilizar as políticas sociais, para as comunidades, porém, de acordo com MACHADO et alii (1987), a ação do Estado assume o significado de ajustar, difundir e colaborar com as diretrizes traçadas, como estratégia de integrar as comunidades ao processo de desenvolvimento capitalista.

Os Programas de Desenvolvimento Rural Integrados, lançados em 1975, tinham como diretriz básica promover a participação da população na formulação dos planos sociais, ao nível da concepção, implementação e avaliação dos projetos, incorporando, aos programas, a noção de planejamento participativo. Para MACHADO et alii (1987), desde o início, implantou-se, como estratégia, nestes programas, a visão expressa de que a organização dos produtores deveria se concretizar, através da constituição de associações Comunitárias, por meio das quais os recursos financeiros seriam canalizados para os agricultores facilitando a estes participarem dos projetos.

O terceiro movimento apontado por BASSO (1992), que se tornou um terreno fértil para o aparecimento de associaçōes de agricultores, constitui os movimentos sociais, principalmente aqueles ligados à questão da terra, ocorridos a partir da década de 80 e onde atuam diversas entidades não 
governamentais e, inclusive, a igreja. Para o Autor, as associações criadas no seio dos movimentos sociais são resultantes de muitas discussões entre agricultores e técnicos assessores das entidades de apoio. Também são frutos de um aprendizado coletivo, adquiridos no processo de lutas pela terra e contra a expropriação da renda. Desta maneira, as associações têm se constituído, para esses agricultores, numa forma de resistência no processo de produção, que é, cada vez mais seletivo e competitivo.

Além destes três movimentos, pelos quais as associações de agricultores tiveram origem e se multiplicaram pelo Brasil, cabe destacar, ainda, o papel importante de alguns governos estaduais, que também contribuiram para que as associações se ampliassem.

Para FLECK (1992), entre as múltiplas estratégias de sobrevivência, reprodução e resistência na terra, dos pequenos produtores, do sul ao norte do Brasil, sem dúvida a formação de associações de pequenos produtores, de caráter econômico, tem sido, nos últimos anos, a forma mais abrangente das tentativas de atenuar e responder aos sucessivos problemas causados por um conjunto de políticas, que tendem a marginalizá-los do circuito produtivo e econômico e a desqualificá-los como produtores e cidadãos.

Estas associações se caracterizam pela forma coletiva de organização do seu processo de produção seja na área da produção, de serviços, de comercialização, entre outros. Assim, a associação representa um grupo de familias que, através da coletivização do seu processo produtivo, busca o enfrentamento e as soluções para os seus problemas.

\subsection{O Planejamento}

A partir da verificação que o homem tem desejos ilimitados, enquanto que os recursos disponiveis para a sua possivel satisfação são escassos e, portanto, limitados, justifica-se, ao nível mais geral, a introdução do planejamento, como forma de previsão do grau de satisfação de suas 
necessidades, pois, nem sempre, os fatos que circundam o homem the são satisfatórios.

Assim, para MENDEZ \& GÓMES (1989), o fato passa a ser encarado como uma barreira a ser superada, um objeto passivel de intervenção, no intuito de modificá-lo em benefício da satisfação das necessidades e dos desejos. Este é, então, o primeiro conteúdo do planejamento. Ainda, segundo os Autores, os bens e serviços capazes de garantir a satisfação almejada são escassos, não estando em livre disponibilidade. Isto quer dizer que sua obtenção é difícil, implicando em custos. Em outros termos, significa que qualquer benefício implica em custos; portanto, segundo os Autores, pode-se inserir os fatos no âmbito do econômico e, em decorrência, o planejamento também.

Temos, portanto, que a diferença de custos entre as várias opções capazes de satisfazer uma dada necessidade ou desejo, estabelece um segundo conteúdo do planejamento: o de viabilizar opções. MENDEZ \& GÓMES (1989), apontam, basicamente, para três tipos de opçōes, quais sejam:

a) Econômica: o que e quanto produzir para satisfazer desejos e necessidades já identificados;

b) Tecnológica: como produzir, isto é, como combinar recursos produtivos com o máximo de eficiência;

c) Social: para quem produzir, no sentido de estabelecer equilibrio entre a eficácia distributiva para satisfazer necessidades e a eficiência distributiva para garantir o retorno.

A partir deste raciocínio, MENDEZ \& GÓMES (1989), definem o planejamento como "o processo contínuo e permanente de pensamento sobre 0 futuro, desenvolvido para estabelecer estados futuros desejados (fins) e avaliar cursos de ação alternativos (meios)".

Para KWASNICKA (1990, p.156), "o planejamento é tanto uma necessidade organizacional como uma responsabilidade administrativa. 
Através do planejamento, a organização escolhe metas baseadas em estimativas e previsões futuras, dando forma e direção aos esforços de administradores e trabalhadores dos demais níveis organizacionais. Os objetivos do planejamento podem ser englobados em: determinar objetivos adequados e preparar para mudanças adaptadas e inovativas". A Autora afirma, ainda, que o planejamento é definido como a atividade pela qual administradores analisam condições presentes para determinar formas de atingir o futuro desejado.

Observamos, assim, que o planejamento é um processo que se caracteriza por ser contínuo, dinâmico e inacabado e não um produto. Outro fator que deve ser observado e, aparentemente lógico, é que se planeja pensando no futuro, procurando atingir um estado desejado e, portanto, diferente do estado atual que se mostra insatisfatório para o sistema de preferências de quem planeja. Para MENDEZ \& GÓMES (1989), planejar, portanto, não é apenas prever ou projetar ou, menos ainda, predizer; implica, sim, numa explicitação de uma vontade de mudança nos fatos econômicos, pois, de outra maneira, a interferência neles seria desnecessária.

HOFFMANN et alii $(1981, p .181)$, afirmam que "o planejamento é um esforço humano, conjunto e organizado, para, modificando a sociedade, acelerar o ritmo de desenvolvimento da coletividade. Ele consta de uma formulação sistemática e devidamente integrada que expressa uma série de propósitos a serem realizados dentro de determinado prazo, levando em consideração as limitações impostas pelos recursos disponiveis bem como as metas prioritárias definidas". 'Para o Autor, portanto, o planejamento, antes de mais nada, é a formulação sistemática de um conjunto de decisões, devidamente integrado, que expressa os propósitos de um indivíduo, grupo ou associação de indivíduos, e condiciona os meios disponíveis para alcançá-los, através do tempo. 1

$\mathrm{Na}$ prática, o planejamento se constitui num processo que, partindo de um conjunto de informações disponíveis sobre um determinado 
ambiente, ao nível dos objetivos que são colocados, tem, como produto final, procedimentos e critérios para a confecção de planos de produção. Assim sendo, teoricamente, o planejamento é concebido como um instrumento eminentemente técnico, usado para a busca de soluções aos problemas, configurando-se, quase sempre, como uma ação individual. Parte-se, portanto, do pressuposto de que a solução dos problemas está ao alcance do administrador, na própria empresa, bastando, para isto, diagnosticar uma situação e aplicar determinadas técnicas para que estes problemas sejam superados. Compreende-se o planejamento como uma etapa do processo administrativo, na qual utilizam-se métodos que evidenciam as práticas a serem empreendidas, ao nivel do processo produtivo, que permitam à empresa maximizar seus resultados econômicos, através da combinação dos fatores de produção disponíveis.

\subsection{O Controle}

Segundo KWASNICKA (1990, p.196), "planejamento e controle estão sempre tão relacionados que chega a ser difícil identificar onde um termina e outro começa. O planejamento representa a antecipação da ação. Controle é um processo ativo que procura manter o planejamento dentro do seu curso inicial". Notamos, assim, que, de nada adianta planejar se a função gerencial de controle não é efetivada. Para BIALOSKORSKI NETO \& NEVES (1993), a tomada de decisão de curto prazo depende de eficientes processos de controle e da flexibilidade do planejamento. Segundo os Autores "a função de controle é a que permite ao empresário aferir, periodicamente, o seu processo de produção. Desta forma, o planejamento se constitui no início do processo administrativo e o controle em uma atividade permanente deste processo". Este processo possibilita medir 0 desenvolvimento dos negócios, comparando 0 controle com o planejado. Por outro lado, havendo desvios no desempenho, estes podem ser corrigidos, através da identificação dos erros, durante o desenvolvimento da produção. 
Se tudo corresse exatamente de acordo com o que foi planejado, não haveria nenhuma necessidade de controle. O controle existe exatamente porque sempre alguma coisa sai diferente do que foi planejado. Assim, o controle se constitui na função administrativa que tem a finalidade de medir e corrigir o desempenho e para assegurar que os objetivos da empresa sejam atingidos. A tarefa do controle é verificar se tudo está sendo feito de conformidade com o que foi planejado e organizado, de acordo com as ordens dadas, para identificar os erros ou desvios, a fim de corrigí-los e evitar a sua repetição (CHIAVENATO, 1990).

A partir de uma conceituação citada por KWASNICKA (1990, p.196), bastante ampla, feita por Robert J. Mockler, em seu livro Management Control Process, tem-se que: "o controle administrativo é um esforço sistêmico de estabelecer padrões de desempenho, com objetivos de planejamento, projetar sistemas de feedback de informações, comparar desempenho efetivo com estes padrões pré-determinados, determinar se existem desvios e medir sua importância e tomar qualquer medida necessária para garantir que todos os recursos estejam sendo usados da maneira mais eficaz e eficiente possível, para a consecução dos objetivos da empresa".

Como instrumento de controle, podemos considerar a contabilidade como de muita utilidade, no processo de geração de informações para a correta gestão e tomada de decisão, nas empresas. Através dela, as atividades podem ser diariamente controladas, através dos registros de todas as ocorrências na empresa. As modalidades mais comuns utilizadas pelos agricultores para guardar informações contábeis e técnicas sobre a sua unidade de produção são: a memória, anotações em cadernos, cópias de projetos de financiamentos das atividades, caixas de sapatos ou pastas e pregos para prender notas e recibos. Observamos, assim, que, com raras exceções, os agricultores não têm o hábito de ter os dados sobre a sua propriedade 
sistematizados para servir de base ao processo administrativo às suas respectivas atividades.

Segundo SANDRONI (1989, p.66), "contabilidade é o setor das ciências de administração que cuida da classificação, registro e análise da todas as transações realizadas por uma empresa ou órgão público, permitindo desta forma uma constante avaliação da situação econômico-financeira. Tem por objetivo o patrimônio econômico das pessoas físicas ou jurídicas, comerciais ou civis, bem como o patrimônio público e as questōes financeiras do Estado. Seu objetivo é permitir o controle administrativo e o fornecimento de informações precisas a investidores, credores e ao público. Envolve todos os aspectos empresariais ou públicos que possam ser expressos em números como o ativo, o passivo, as receitas e despesas, os lucros e perdas e os direitos de investidores".

FRANCO (1986, p.13), assim define a contabilidade: "é a ciência que estuda e controla o patrimônio das entidades, mediante o registro, a demonstração expositiva e a interpretação dos fatos nele ocorridos, com o fim de fornecer informações sobre sua composição e suas variações, bem como sobre o resultado econômico decorrente da gestão da riqueza patrimonial".

Isto, em outros termos, significa que a contabilidade, enquanto instrumento gerencial, tem a finalidade de fornecer informações econômicas relevantes, para que cada usuário possa tomar suas decisões e realizar seus julgamentos, com segurança. Isto exigirá um conhecimento do modelo decisório do usuário, através da identificação das informações consideradas mais relevantes ou das metas planejadas. Embora um conjunto de informaçōes financeiras consubstanciadas nos relatórios periódicos principais deva satisfazer às necessidades básicas de um bom número de usuários, a contabilidade ainda deve ter flexibilidade para fornecer conjuntos diferenciados para usuários ou decisões especiais. Isto deveria ser possivel sem introduzir traumas no sistema. 
Existem dois tipos de contabilidade que podem ser utilizados, a nível da unidade de produção: a contabilidade pelo método das partidas dobradas e a contabilidade pelo método das partidas simples, ou contabilidade simplificada.

SOUZA (1989), afirma que a escolha de um destes dois sistemas vai depender dos objetivos do empresário. Para o autor, o sistema de partidas dobradas é o oficialmente aceito, usado, universalmente, por empresas, urbanas e rurais. Apresenta, como vantagem, a facilidade de interpretação e análise dos dados registrados; como desvantagem, a complexidade da organização e dos lançamentos, o que obriga a existência de pessoal especializado.

Ainda segundo SOUZA (1989, p.166), "o método simplificado é bem mais fácil de ser operacionalizado, sendo bastante adequado para as pequenas e médias empresas rurais, que, por força de lei, não são obrigadas a manter uma escrituração regular. Dependendo de como o sistema é organizado, podem-se obter informações extremamente úteis no processo de planejamento, organização, direção e controle de uma empresa".

O pressuposto do método de partidas dobradas é que toda aplicação de recursos, isto é, todo investimento tem uma origem ou financiamento e que, portanto, tudo o que se possui veio de algum lugar, ou seja, não se pode aplicar recursos se não houver primeiro uma fonte dos mesmos. A parte operacional deste sistema está fundamentada na existência de um lançamento onde se utilizam, sempre, duas contas: uma devedora e outra credora. Assim, a contabilidade regular pressupõe a existência de um plano de contas que norteia todo o processo de registros dos atos e fatos e, por outro lado, o método se utiliza de livros auxiliares de escrituração. O resultado do exercício é obtido mediante o levantamento do balanço patrimonial e dos demais demonstrativos contábeis. 
De acordo com BASSO (1975), o método de partidas simples, ou a contabilidade simplificada, é aquele que se apresenta mais naturalmente aos leigos em contabilidade, porque é quase despida da técnica contábil. Chamase simples ou livre, porque o seu "operador" abre as contas que achar suficientes para escriturar as transações do seu empreendimento, sem se preocupar com a causa e o efeito das variações econômicas, no patrimônio.

Este sistema de registro de dados é bem menos complexo do que $o$ anterior e não envolve lançamentos, mas apenas o registro das despesas e das receitas de cada atividade. O método pode, ainda, registrar as variações ocorridas no patrimônio da unidade de produção, bem como os novos investimentos. Os registros simplificados podem assumir, perfeitamente, a missão de gerar, de organizar, e de sistematizar as informações gerenciais de natureza econômico-financeira e técnica, relacionadas ao processo de produção, tornando-se, assim, um instrumento de apoio ao planejamento e de avaliação das decisões tomadas pelo agricultor.

Para TUNG (1992), um sistema de registros supersimplificado, sem a utilização da técnica contábil tradicional de lançamentos duplos, e sem a noção de débito e crédito que confunda, até graduados em contabilidade, efetivamente ajudará o pequeno agropecuarista e pode se constituir numa das soluções frente à problemática do controle da produção, com vistas à obtenção de informações gerenciais.

SOUZA (1989, p.169) diz que "uma das grandes vantagens da contabilidade simplificada é que ela possibilita o conhecimento de um conjunto de coeficientes técnicos úteis para o planejamento e controle das atividades produtivas da empresa".

A história da contabilidade agricola simplificada surgiu, no Brasil, em 1964, com o livro do professor Erly Dias Brandão, entitulado Contabilidade Simplificada. Posteriormente, instituições como o serviço de Extensão de Minas Gerais e a Secretaria da Agricultura do Estado de São Paulo 
passaram a adotar modelos de contabilidade simplificada, permitindo a seus técnicos informações de melhor qualidade, obtidas das próprias unidades de produção.

O principal problema com os livros e formulários de contabilidade simplificada é que, apesar de simples, para pessoas com um nivel médio de conhecimento, sua adoção, pelos agricultores, com raras exceções, não foi bem sucedida. Segundo SOUZA (1989, p.168), "o método lhes pareceu complexo, faltam a eles motivação e percepção quanto às suas vantagens. $O$ que para um Técnico é muito simples pode parecer complicado para um Agricultor de porte pequeno ou médio, e que em alguns casos possui baixo nivel de escolaridade".

PÉRES \& NORONHA(1985), acredita que o "relativo insucesso das tentativas deve-se, principalmente, a duas causas: a primeira é a ausência prática da obrigatoriedade fiscal. Ao contrário do caso americano, no qual o professor Erly Dias Brandão se baseou, os agricultores brasileiros, em geral, não pagam impostos diretos (sobre a renda). Como a taxação indireta independe dos demonstrativos contábeis, os agricultores nunca foram estimulados a manter anotações mais detalhadas". A segunda razão apontada, "que pode explicar o pouco estímulo à adoção da contabilidade pelos agricultores, pode ser encontrada nas altas taxas inflacionárias que prevalecem na economia desde a metade do século, agravadas pelas distorções derivadas das interferências do governo nos mercados de produtos e de insumos. Com altas taxas de inflação e na ausência de um índice facilmente reconhecido pelos agricultores, a defasagem temporal entre a ocorrência do fato econômico e a análise contábil, praticamente impede o agricultor a apreciar as vantagens da contabilidade na condução dos seus negócios. Como a análise contábil demandava muito tempo para ser completada, seus resultados apresentavam pouco interesse prático como instrumento auxiliar no processo de tomada de decisão dos agricultores. Adicionalmente, os ganhos advindos do 
acompanhamento contábil dos negócios de um Agricultor deviam ser modestos quando comparados aos derivados dos benefícios auferidos com o acesso maior aos subsídios do crédito, por exemplo. Resumindo, os retornos esperados com o uso da contabilidade eram menores que os custos, em tempo e em dinheiro, requeridos para a sua utilização".

Mesmo com estes e outros problemas, muitos trabalhos, principalmente os relacionados à administração rural, têm se utilizado da contabilidade como fonte de informações para o processo de tomada de decisão das unidades de produção.

\subsection{Algumas Experiências Práticas}

Segundo CORDONNIER (1973, p.25), "na França, a contabilidade agrícola, durante um longo período de tempo, mostrou um desenvolvimento muito limitado. Numa pequena empresa agrícola, onde os impostos são calculados com base num benefício estimado e onde o autoconsumo de produtos é um fator importante, a contabilidade tem sido freqüentemente considerada inútil. Porém o setor agrícola não podia figurar como um mundo aparte. Assim, na França, nos últimos anos, foram criados muitos centros de gestão nos quais os "engenheiros" têm por missão, entre outros, a análise do funcionamento da empresa agrícola a partir dos elementos registrados por uma contabilidade simplificada".

No Estado de Santa Catarina, o Serviço de Extensão Rural ACARESC, se utiliza da comparação de grupo como técnica de análise e diagnóstico de grupos de agricultores. O método parte dos resultados econômicos, classificando as propriedades em: cabeça, média e cauda. Os índices restantes explicam o desempenho, a partir do lucro. $O$ trabalho permite, segundo HOLZ (1986, p.7), "sugerir aos grupos de cauda e média mudanças no sistema de produção, no uso do solo, incremento nas atividades animais, 
melhoria das margens brutas com 0 aumento do produto bruto e encargos variáveis, mudanças tecñológicas nas atividades bem como sugestōes de melhoria da estrutura de produção. Estas mudanças podem ser feitas, antes de tentar otimizar o lucro, porque já existem referências técnicas e econômicas no meio rural, disponiveis entre os melhores produtores".

Numa explicação de BARROS (1964), a comparação de grupo se define como sendo um método em que se confrontam os índices técnicos e econômicos, considerados como os principais, aferidos de um conjunto de explorações, para $\circ$ qual se verifique adequado equilíbrio entre a homogeneidade dos recursos naturais e econômicos disponíveis e a heterogeneidade do seu efetivo aproveitamento, de modo a distinguir relações entre os sistemas de produção adotados e os resultados obtidos.

O processo de obtenção dos dados individuais, segundo HOLZ (1986), do conjunto de propriedades que compõe o grupo é por contabilidade ou por enquete, Ainda segundo $\operatorname{HOLZ}(1986$, p.9), "o processo de análise visa descobrir as normas-chave, que determinam para o grupo de cabeça os resultados melhores. Para tanto, são analisadas as correlações do lucro com a estrutura, com o sistema de produção, com a tecnologia de produção e com o mercado. Os resultados ensejam um diagnóstico para imediatamente replanejar o sistema de produção, a tecnologia em uso e a estrutura da exploração agrícola. Para a média e cauda usam-se as referências da cabeça, para o grupo da cabeça, buscam-se normas fora do grupo, através da orçamentação ou da otimização".

A Secretaria da Agricultura e Abastecimento do Estado de São Paulo, através da Coordenadoria de Assistência Técnica Integral - CATI, há muitos anos desenvolve um Projeto de Administração Rural. O Projeto usa, como sistematizador das informações, o Caderno de Escrituração Agrícola e tem como objetivo a adoção do caderno, por parte do agricultor, com a finalidade de auxiliálo em suas decisões. 
Na CATI, o Caderno de Escrituração Agrícola foi elaborado com uma preocupação central: a seqüência de anotações deveria ser a mais simples possivel, de maneira a oferecer uma análise clara do comportamento real da propriedade em estudo. Por outro lado, é importante frisar que não se trata de um caderno fiscal, mas destinado a anotações, para melhor gerenciar a empresa agrícola, ficando o agricultor de posse dos dados.

Mais recentemente, em 1992, a CATI lançou a Agenda de Escrituração do Produtor Rural, que procura dar continuidade ao Projeto de Administração Rural. Segundo BIALOSKORSKI NETO \& BIANCO (1992, p.7), "com esta agenda, a CATI pretende ajudar a agricultor a realizar uma simplificada contabilidade rural. Desta forma, no fim de cada mês, o Agricultor terá uma série de dados, através de um conjunto de tabelas, que o ajudarão a controlar os gastos com a produção e as receitas recebidas com as vendas dos produtos, e poderá ainda fazer o seu planejamento prévio".

A Agenda de Escrituração do Produtor Rural se inicia com as tabelas de planejamento que poderão ajudar o Produtor a escolher as atividades que serão desenvolvidas, bem como o sistema de produção a ser adotado. Depois, apresenta uma série de tabelas mensais de despesas e de receitas que devem ser preenchidas, toda vez que acontecer um gasto qualquer (despesa) ou quando ocorrer alguma venda (receita). Também, mensalmente, deve ser preenchida uma tabela de gastos com a maquinaria e com a mão-de-obra. Para BIALOSKORSKI NETO \& BIANCO (1992, p.8), "com as duas tabelas multiplicadas e preenchidas mês a mês, o produtor saberá no final do ano quanto custou determinada atividade e se houve lucro ou perda de dinheiro na exploração agrícola, o que pode ser visto numa série de tabelas anuais que, além de mostrar os ganhos ou as perdas nas atividades, possibilitam a obtenção do resumo anual de caixa, podendo o Agricultor com isto, planejar seus pagamentos, inclusive os de financiamentos, se for o caso". 
Outro trabalho na área da Administração Rural que procura se utilizar da Contabilidade Simplificada é o Programa de Administração Rural (PAR) da Universidade Regional do Noroeste do Estado do Rio Grande do Sul (UNIJUÍ). O PAR tem um enfoque eminentemente educativo, é desenvolvido junto a pequenos agricultores da Regional Sindical de Passo Fundo e tem como objetivo central capacitar e instrumentalizar, técnica, econômica e administrativamente, pequenos agricultores, para que consigam aumentar a racionalidade e a eficiência a nível de organização e condução de suas unidades produtivas.

O PAR se utiliza de um conjunto de três formulários. Os formulários 1 e 2 são para o registro das operações de apenas uma atividade, geralmente a principal, e são utilizados durante os dois primeiros anos do trabalho. No formulário 1 , apenas registram-se as operações que envolvem entradas e/ou saídas em dinheiro, e permite apurar a margem bruta da atividade ou o seu fluxo de caixa. No formulário 2 , além do fluxo de dinheiro na atividade, também são registrados os custos fixos da atividade. Para tanto, se faz necessário o levantamento de um inventário parcial. Este formulário permite determinar, além da margem bruta, o custo de produção e o resultado líquido da atividade.

O formulário 3 serve para analisar o resultado econômico de toda a propriedade, durante um ano. Permite apurar a Renda da Operação Agrícola (ROA), através do controle e registro de todas as atividades desenvolvidas na unidade de produção. Para tanto, é necessário fazer o levantamento completo do inventário da propriedade, bem como o registro de todas as entradas e saídas em dinheiro. Este formulário permite apurar: a margem bruta das atividades (fluxo de caixa de cada atividade); o fluxo de caixa do conjunto das atividades; o custo de produção e o resultado líquido das atividades; a renda da operação agrícola e, se for o caso, o balanço patrimonial da propriedade. 
Nos três formulários existe um espaço para o registro das operações técnicas que 0 agricultor achar necessário. Isto possibilita a sistematização das informações de natureza técnica, as quais, em muitos casos, ajudam a explicar o desempenho econômico das atividades.

Estes três formulários são assim divididos, com o objetivo de respeitar o raciocínio lógico do agricultor e a sua progressividade, uma vez que, primeiro, o agricultor controla o fluxo de caixa de apenas uma atividade; num segundo momento, também passa a controlar o seus custos fixos, para, somente num terceiro estágio, controlar toda sua propriedade.

No PAR ficou evidente que a prática do planejamento é uma ação permanente, entre os agricultores, pois eles traçam planos no dia-a-dia, principalmente em relação ao que produzir, como produzir, que recursos utilizar, etc. Existem determinados períodos em que essa atividade é melhor identificada, ou seja, quando os trabalhadores intensificam o seu trabalho de planejar. É o caso dos períodos de entressafra, nos quais a reflexão sobre o processo de produção é mais intensa e profunda e de onde se originam as decisões em relação às atividades futuras. Diante disto, a etapa do planejamento procura aperfeiçoar o trabalho que os agricultores já vêm desenvolvendo neste campo, colocando à sua disposição técnicas que Ihes permitem sistematizar seus planos, quantificá-los e, com isto, facilitar-lhes a tarefa de tomarem decisões sobre as situações com as quais estão envolvidos.

Com isto podemos caracterizar a etapa de planejamento no PAR como sendo:

a) Um momento de identificação e discussão dos problemas individuais e coletivos, onde agricultores e técnicos debatem e, juntos, buscam as soluções cabiveis para cada caso;

b) Um momento de troca de experiências, quando as dificuldades e os planos são explicitados e comparados; 
c) Um momento de projeção e sistematização, a partir das informações e dos conhecimentos veiculados no grupo, onde cada agricultor, valendo-se de técnicas de planejamento, faz suas próprias contas visando avaliar, qualitativa e quantitativamente, os resultados econômicos, decorrentes do ato de planejar.

No que concerne às técnicas de planejamento, a prática mostrou que, entre as existentes, aquela que melhor se aplica às unidades de produção familiar é a orçamentação, pois é uma técnica que facilita o trabalho de sistematização e avaliação dos planos de produção dos agricultores. É uma técnica simples e de fácil assimilação e que permite a quantificação dos resultados físicos e econômicos de um plano, bem como permite uma avaliação dos aspectos de ordem política e social do planejamento.

Se deixarmos de lado a questão da contabilidade simplificada, em propriedades agrícolas, observamos que são raros os trabalhos desenvolvidos, nesta área, com associações de pequenos agricultores. Porém, com o apoio de suas organizações representativas e de um grande número de agentes e técnicos de Pastorais da Igreja, de Organizações Não Governamentais (ONGs) e outros, vão, pouco a pouco, constituindo mecanismos de gestão. Entretanto, segundo FLECK (1992), no plano da gestão econômico-financeira, no que tange à implantação de princípios e instrumentos adequados às suas necessidades, à sua concepção político-pedagógica e às suas escalas operacionais, situa-se claramente um limite para a consolidação dessas associações, também, pela insuficiente formação dos agentes de desenvolvimento, nessa área.

Em função destas limitações, a rede de Assessoria e Serviços a Projetos em Agricultura Alternativa (AS-PTA), aceitou a incumbência da adaptação do manual de Gestão Prática, de Fernand Vicent, editado, originalmente, em francês. Assim, a versão brasileira foi editada numa série de fascículos que procuram discutir, no seu conjunto, os principais problemas enfrentados no dia-a-dia das associações. A série procura ser um instrumento de 
apoio à organização e à administração de programas e experiências de desenvolvimento. Uma das publicações da série, escrita pelo Professor Martinho Kelm, se preocupa com o controle financeiro e procura propor alguns procedimentos que permitam, a uma associação de agricultores, exercer o controle econômico e financeiro de suas operações.

Para KELM (1992, p.1), "estes instrumentos visam suprir uma carência verificada nas associações no que se refere à falta de informações sistematizadas e confiáveis que permitam à diretoria e ao conjunto dos associados avaliar o desempenho da associação e tomar decisões futuras". Ainda, segundo o Autor, "quando um grupo de pessoas resolve constituir uma associação, as dificuldades se ampliam e novos aspectos e questões precisam ser levados em conta. É inegável que a opção por uma forma coletiva de organização do trabalho significa um avanço em termos de fortalecimento econômico e político dos agricultores. Porém, esta forma de trabalho traz consigo novas situações e responsabilidades com as quais não se está acostumado".

$\mathrm{Na}$ associação, os negócios e os resultados passam a ser de interesse e responsabilidade do conjunto dos agricultores. As decisões passam a ser tomadas em grupo ou, no mínimo, pela diretoria. Isto faz com que o conjunto dos associados passe a se interessar por questões relativas ao desempenho e à real situação da associação, tais como: quanto dinheiro se dispõe? qual o valor das dividas? que atividades estão dando lucro? entre outras. $\operatorname{KELM}(1992$, p.2), afirma que "somente a partir de um sistema da informações eficiente e confiável pode-se obter não só as respostas a essas questões, como também subsídios valiosos para o enfrentamento dos problemas e dos obstáculos que normalmente intervêm no funcionamento e no desempenho de uma associação".

A partir destas preocupações, KELM (1992) apresenta três grupos característicos de controles internos que, em conjunto, formam um sistema de informações gerenciais. Estes grupos são compostos, basicamente por: 
a) Instrumentos que visam informar e controlar o fluxo financeiro da associação (basicamente entradas e saídas de dinheiro) que são representados pelo controle do caixa e bancário.

b) Instrumentos que visam informar sobre a situação patrimonial da associação, ou seja, a posição de seus bens, direitos e obrigações. Este grupo é representado pelo controle das operações com associados, fornecedores, instituições financeiras, estoque e inventário patrimonial.

c) Instrumentos que visam demonstrar o resultado da associação e das diversas atividades por ela mantidas. Essas informações são apuradas, através dos formulários e das planilhas de controle da produção.

Os instrumentos de controle propostos por KELM (1992) estão didaticamente estruturados para manter uma certa independência entre si. Isto significa dizer que, se na associação existir algum tipo de controle ou de contabilidade, os que estão sendo propostos poderão complementar ou então aperfeiçoar os existentes. Caso a associação esteja iniciando um processo de controle financeiro, $\operatorname{KELM}(1992$, p.2), afirma que não se deve ter a preocupação de implantar todos os controles, de uma só vez: a independência que mantêm entre si, onde o controle subseqüente não inviabiliza o anterior, apenas o aperfeiçoa, faz com que, progressivamente, as modalidades de controle evoluam. Com isto, a diretoria e os associados passam a se habituar com os controles e, naturalmente, percebem a necessidade e a importância de maiores informações. 


\section{METODOLOGIA}

\subsection{A Associação de Agricultores de Nova Ronda Alta (AANRA)}

Para a realização deste trabalho, será feita uma pesquisa qualitativa na qual procurar-se-á identificar e analisar, na Associação de Agricultores de Nova Ronda Alta (AANRA), o modelo de planejamento e controle da produção que serve de base ao processo decisório. Como o presente trabalho se constitui em estudo de caso, a escolha da AANRA ocorreu pelo fato de entender-se que ela reúne características que são comuns às demais associações de pequenos agricultores. Por outro lado, as entidades que atuam junto às associações participaram na sua escolha.

De acordo com VIEIRA (1990), "a experiência dos trabalhadores rurais de Nova Ronda Alta representa, sob a ótica da teoria organizacional, uma forma alternativa de organizar o trabalho e a produção. $O$ modelo burocrático de organização, forma predominante na sociedade moderna, possui uma série de características não observadas, a princípio, na estrutura organizacional da AANRA".

Ainda segundo VIEIRA (1990), "na AANRA a hierarquia é de natureza diferente da organização burocrática. Enquanto que na burocracia a hierarquia está baseada no cargo, onde o indivíduo detém as prerrogativas do cargo, na Associação a hierarquia é do coletivo sobre o individual. $O$ poder concentra-se em um único nível, representado pela coletividade como um todo. Neste nivel (Assembléia dos Agricultores), são tomadas as decisões que dizem respeito à Associação, e através dele a organização mantém relações com o ambiente". Isto significa dizer que, na AANRA, o processo decisório funciona de forma coletiva. Neste coletivo são tomadas as decisões estratégicas, que dizem 
respeito ao funcionamento interno e às relações externas, ou seja, todo o processo decisório passa por todos os membros da entidade.

A organização interna da Associação é constituída por setores de trabalho, que formam o nivel de execução das atividades. Estes setores possuem encarregados pela sua manutenção. Os membros responsáveis por cada setor de trabalho não têm autoridade para decidir, sozinhos, sobre os assuntos que the dizem respeito, nem trabalham apenas em um setor especifico. Estes membros têm a responsabilidade de levar para a Assembléia dos Agricultores os problemas encontrados na manutenção e andamento de cada setor, para que todos possam avaliar e tomar decisões que são tomadas de forma coletiva. De acordo com o estatuto da Associação, tais decisões deveriam ser tomadas por maioria simples; no entanto, a prática cotidiana mostra que são por consenso, precedidas por um processo de ampla discussão.

O modelo coletivo de tomada de decisão, que ocorre na AANRA, de acordo com VIEIRA (1990), opõe-se ao modelo burocrático, uma vez que este atribui a cada nível hierárquico um tipo específico de decisão a ser tomada. MOTTA \& PEREIRA (1986), observam que as decisões estratégicas ficam sob a responsabilidade dos níveis hierárquicos intermediários, e as decisões operacionais são tomadas pelos próprios executores.

Ainda, segundo VIEIRA (1990), na AANRA não há definição clara do nível tático de decisão, em função da estrutura organizacional e administrativa da Associação e do próprio modelo coletivo de tomada de decisão. Este modelo foi definido, por HARDY et al. (1984), como um modelo, dentro do qual, os interesses comuns tendem a guiar e orientar os processos de decisão. As decisões de nível operacional ficam a cargo dos executores, embora, muitas vezes, até este tipo de decisão seja levado às reuniões para avaliação. 
Outro aspecto importante é a questão do conhecimento. $\mathrm{Na}$ AANRA, o conhecimento é caracterizado pela baixa especialização e pela multiplicidade. Isto se dá em função da natureza das atividades que a associação desenvolve e pela tecnologia adotada. Parece evidente a existência de diversidade e de diferenças no conhecimento específico, devido à atuação de cada membro ou a sua experiência anterior. Contudo, também existem mecanismos que dificultam o aparecimento da autoridade baseada apenas no conhecimento, como a rotação de tarefas, tanto nos trabalhos internos como externos (movimentos populares).

Mesmo que alguns dos seus membros se destaquem pelo seu conhecimento, o fato que chama atenção é a rotação, entre os associados, das responsabilidades sobre 0 andamento das atividades. Em outros termos, existe na associação o incentivo para que todos os membros assumam, consecutivamente, a condição de responsável pela operacionalização das atividades diárias. Este fato, está baseado na forte consciência dos membros da organização de que o coletivo é mais importante do que o individual e que tudo deve estar subordinado a ele.

\subsection{Procedimentos Metodológicos}

Como procedimento metodológico de coleta de dados, bem como técnica de captação da realidade das associações, usar-se-á a observação-participante, que será complementada com um roteiro de entrevistas. O roteiro de entrevistas constitui-se, na verdade, de um conjunto de idéias, as quais deverão nortear todo processo de obtenção dos dados. Isto significa dizer que não se pretende fazer um roteiro formal de entrevistas, constituído a partir de um conjunto de questionamentos pré-determinados, os quais deveriam nortear toda a discussão com os membros da Associação. Na verdade, a entrevista será 
realizada a partir de idéias e colocações dos próprios membros, sobre as suas tarefas e atividades. A partir destas colocações é que serão obtidas as informações para o trabalho final.

Todos os associados da AANRA foram envolvidos com o processo de obtenção de dados, sendo que a documentação apenas se preocupou com as informações que, de alguma forma, se relacionam com o processo de planejamento e de controle da produção da associação.

A observação participante, segundo HAGETTE (1987), é uma técnica de coleta de informações onde a investigação se dá, num processo de interação entre observador e observados. Significa, então, compreender a realidade, através da interação do pesquisador com a realidade pesquisada.

Segundo SOUZA (1984) a pesquisa participante pode ser identificada como um tipo de pesquisa social, onde a produção do conhecimento se dá na ação ou na busca de soluções, para angustiantes problemas da sociedade. Para PINTO (1986), a pesquisa participante tem como perspectiva epistemológica não conceber a verdade como preexistente nos fatos sociais. Para o Autor, a verdade se constrói, a partir de aproximações sucessivas, ao objeto investigado. Nesta perspectiva, o que se busca é a compreensão qualitativa do social, deixando, assim, a quantificação de ser essencial à compreensão dos fatos sociais. O aprofundamento desta questão permite responder às criticas que se fazem à pesquisa qualitativa, pelo fato dela não formular hipóteses conceituais e operacionais que possam ser submetidas à comprovação. Destaca-se 0 fato da pesquisa-participante também permitir a obtenção de dados quantitativos. Neste caso, os dados podem ser obtidos mediante a realização de uma série de enquetes com os entrevistados.

Frente a isto, a pesquisa qualitativa não tem como finalidade apenas desenvolver ou analisar determinadas situações, estudar determinadas 
relações ou, ainda menos, descrever as características objetivas e subjetivas da situação, por mais importante que isto possa ser, em termos do conhecimento científico. Busca, sem dúvida, compreender a situação objetiva e concreta, bem como a percepção que dela se tem. Porém, busca acima de tudo, produzir os conhecimentos necessários para definir ações que estejam na linha das transformações para se conseguir um desenvolvimento integrado

Em síntese, PINTO (1986) entende a pesquisa participativa não como um método único ou unificado, formalmente constituído por um conjunto logicamente estruturado (sistemático) de orientações, atividades e procedimentos, mas como uma prática social de produção de conhecimentos que buscam a transformação da realidade social, vista como totalidade. Assinala também o caráter novo e inovador desta prática, na medida em que o conhecimento científico se produz na própria ação, ao mesmo tempo que contribui para ele.

Assim, na pesquisa participativa, os pesquisadores desempenham um papel ativo no equacionamento dos problemas encontrados, no acompanhamento e na avaliação das ações desencadeadas, em função dos problemas. Para THIOLLENT (1947, p.20) "no contexto organizacional, onde há nítida divisão entre dirigentes e dirigidos, é claro que a pesquisa participante pode ficar repleta de ambigüidades e seu alcance pode ser limitado de modo utilitarista por parte dos dirigentes ao colocarem problemas de seu exclusivo interesse como prioritários, independentemente de sua relevância científica".

Ainda, segundo o mesmo Autor, quando se trata de pesquisa participante, voltada para os problemas de coletividade, como por exemplo a organização do trabalho em mutirão, os objetivos práticos consistem em fazer um levantamento da situação e formular reivindicações e ações. São objetivos práticos, voltados para se encontrar uma saída, dentro do contexto. Esses objetivos práticos não devem nos fazer esquecer que a pesquisa participante, 
como qualquer estratégia de pesquisa, possui também objetivos de conhecimento que, a nosso ver, fazem parte da expectativa científica que é própria às ciências sociais.

O papel do pesquisador, neste caso, ocupa uma posição de relevo. Constitui-se em uma espécie de observador privilegiado. Segundo ALVES (1988), "o observador é sempre um editor: aquele que transforma o comportamento do sujeito em uma linguagem e em um sistema de registro. Para cumprir a sua tarefa o pesquisador que trabalha com observação, neste primeiro momento, tem que definir que tipo de recorte vai fazer no fluxo do comportamento do sujeito, e isto vem determinado pelos objetivos do seu trabalho, o que por sua vez foi condicionado pela abordagem conceitual que adota". Ainda, segundo o mesmo Autor, "dir-se-ia que o pesquisador-observador "recorta" a realidade segundo significados e funções que "vê", "percebe" e então "atribui" as ações. Portanto ele edita a realidade, e ao fazê-lo traz consigo toda a sua bagagem de vivências, conhecimento e pressupostos teóricos, e porque não dizer, até de hipóteses não formalmente explicitadas" (p. 489-490).

A interação em torno de um tema específico entre o pesquisador e o participante tem, como um dos resultados, o que SIMÃO (1989, p.196), chama de construção do conhecimento: "ao longo do tempo, sob as condições da própria interação, as informações sobre o tema vão se modificando, se transformando, e é esse processo que estou chamando de construção do conhecimento".

Para ZANELLI (1992), os dados jamais podem ser analisados, sem levar em consideração este contexto de interação. Neste processo, o conhecimento é produzido como resultado do engajamento entre o pesquisador e o participante. Para o Autor, esta postura, frente ao ato de pesquisar, assume a objetivação. $O$ conhecimento é gerado em um processo de participação mútua e em um contexto de forças sociais, atitudes e valores. 
Pressupõe, também, autonomia e ação auto-estabelecida, dentro de um mundo, no qual, seüs participantes são capazes de modificá-lo. A possibilidade de mudança de cada um está associado à produção deste conhecimento ativo.

Para REASON \& ROWAN (1981, p.489-491), o conhecimento que se produz deve ser útil aos nossos propósitos de intervenção. O poder que resulta da pesquisa será conseqüência das estratégias que serão empregadas e do tipo de conhecimento obtido. ZANELLI (1992), afirma que a solução de problemas, nas organizações sociais, está associada ao processo de tomada de decisões; este é, por sua vez, explicitamente um processo político.

A estratégia escolhida pretende a construção de conhecimento que permita melhor visualização do problema, em foco. Tal visualização pode conduzir a intervenções que, revestidas de força suficiente, podem alterar o estudo em que se encontra a organização. Para ZANELLI (1992), a linguagem é um elemento central e permeia todo o processo que se estabelece na interação entre o pesquisador e 0 participante, até produzir um tipo de conhecimento que será profícuo, ou não, no contexto em que foi construído.

BORI \& colaboradores (1978), estabelecem um procedimento para a obtenção das informações do participante, através de interações planejadas, entre o pesquisador e o participante, norteadas pelo problema da pesquisa. Segundo SIMÃO (1989. p.197), "o referido procedimento de coleta de informações, envolve a reapresentação sistematizada dos relatos do sujeito de sessão para sessão, de modo que na segunda sessão o sujeito conta, para prosseguir seu relato, com a reapresentação sistematizada do que havia dito na primeira sessão a respeito do tema, na terceira sessão com o que havia dito na segunda e na primeira, e assim por diante". O retorno, dentro da visão adotada no desenvolvimento da estratégia ora apresentada, tem como principal objetivo a checagem das interpretações de falas fornecidas, em sessões anteriores, e estimular novas verbalizações dos participantes. 
Para ZANELLI (1992), uma das alternativas de análise do discurso consiste na organização e entendimento das categorias de relações entre as partes do discurso, que nos interessam, de acordo com o encadeamento dos conteúdos. O exame do encadeamento dos conteúdos enquadra-se em uma maneira de organização do discurso humano. O presente procedimento se mantém voltado para a análise dos conteúdos, não apenas na coleta: faz, dos conteúdos, os próprios resultados da pesquisa. Assume, assim, explicitamente, portanto, uma obtenção de dados simultânea à análise dos conteúdos e considera os conteúdos, de interesse, como os resultados. 


\section{CARACTERIZAÇÃO REGIONAL DA LOCALIZAÇÃO DA AANRA}

Esta parte do trabalho tem por objetivo relacionar algumas informações sobre a evolução de alguns dados sócio-econômicos da região, bem como sobre o município de Ronda Alta. Os demais municípios considerados para a região são aqueles que fazem divisa com o município de Ronda Alta. Os municípios são: Campinas do Sul, Constantina, Jacutinga, Liberato Salsano, Nonoai, Passo Fundo, Rondinha, São Valentim e Sarandi. Os dados do município de Passo Fundo também são apresentados por ser este o maior dos municípios que compõem a região em estudo.

A região em estudo faz parte da denominada Região de Passo Fundo, e tem sua estrutura econômica orientada, a partir de um processo de ocupação da fronteira agrícola, iniciada em meados do século, por imigrantes alemães, italianos, luso-brasileiros, entre outros, sendo que eles influenciam, ainda hoje, em grande parte, o processo de desenvolvimento das atividades econômicas.

As transformações ocorridas na economia brasileira, nos últimos 40 anos, demonstram a passagem de um país com características agrário-exportador para uma sociedade cada vez mais urbana e industrializada. Estas transformações trazem, como reflexo, um número crescente de problemas a serem enfrentados, não apenas ao nível geral da Nação, como também, e principalmente, ao nível das comunidades locais, ou seja, das regiões e dos municípios. Assim, cada comunidade tem a sua evolução histórica, que precisa ser analisada, adequadamente, em todos os seus aspectos. Desta forma, a região guarda íntima relação com as transformações ocorridas a nível nacional, porém, tem as suas especificidades que vêm se modificando, ao longo do tempo.

A atividade predominante na região tem sido a agropecuária, caracterizada, mais especificamente, pela cultura intensiva de lavouras 
temporárias e com atividades de pecuária. Estas duas atividades são, sem dúvida, as responsáveis pela dinâmica dos municípios desta região, surgindo daí as ramificações que configuram o perfil econômico regional. Mais recentemente, começa a surgir, entre os agentes econômicos responsáveis pelo processo de desenvolvimento da região, a necessidade da diversificação das culturas como forma de evitar, em parte, o processo migratório rural-urbano e o uso mais eficiente e racional dos solos. A estrutura fundiária, tanto em número de estabelecimentos como em área, têm expressividade nos extratos até 50 hectares, caracterizando a existência de pequenas propriedades como a categoria predominante, considerando o tipo de cultivo e o uso do solo da região.

Paralelamente ao desenvolvimento agropecuário, a região vem desenvolvendo o setor industrial, ainda pouco significativo, o qual se especializou na produção de máquinas e implementos agrícolas. É importante salientar que o setor ainda não tomou uma dinâmica própria de desenvolvimento. Os efeitos do comportamento do setor primário influenciam, decididamente, o seu desempenho.

Observa-se que, a partir de 1980 , período no qual o Governo Federal inicia um gradual processo de retirada de subsídios ao setor primário, que o desempenho da agropecuária fica cada vez mais dependente de fatores não controláveis (como o clima) e, menos, ao uso, intensivo, do capital. Em conseqüência, o incipiente setor industrial sofre, paralelamente, uma forte retração, acompanhando a queda do setor primário, na dinâmica da economia.

O setor terciário desta região caracteriza-se, em grande parte, pela comercialização, principalmente de gêneros ligados ao setor agrícola, tais como: máquinas, implementos, fertilizantes, defensivos, ou seja, responde, em grande parte, pelas demandas do setor primário. Paralelamente, desenvolvese, no setor terciário, a comercialização de gêneros que atendem às demandas surgidas, em função do fluxo de urbanização, como lojas de confecções, calçados, farmácias, entre outras. Observa-se que este tipo de gênero também 
está condicionado pelo nível de renda da população regional. Ressalta-se a importância do setor terciário para a economia regional, pelo grande número de estabelecimentos e por ser esta uma das únicas alternativas de absorção da mão-de-obra excedente, seja esta urbana ou rural.

De acordo com os dados da tabela número 01, pode-se verificar um crescimento populacional menor na região que no estado do Rio Grande do Sul, bem como um crescimento maior no município de Passo Fundo, o que demonstra que ocorreu um êxodo populacional dos municípios menores, para o maior. Outro dado que se pode observar é o êxodo rural-urbano, nos municípios estudados.

Tabela 01 - Evolução da população urbana, rural e total no período de 1970 a 1991

\begin{tabular}{|c|c|c|c|c|c|c|c|c|c|}
\hline ITENS & \multicolumn{3}{|c|}{ URBANA } & \multicolumn{3}{|c|}{ RURAL } & \multicolumn{3}{|c|}{ TOTAL } \\
\hline ANOS & 1.970 & 1.991 & VAR, $70 / 91$ & 1.970 & 1.991 & VAR. 70/91 & 1.970 & 1.991 & $\mathrm{VAR} .70 / 91$ \\
\hline P. FUNDO & 70.869 & 137.217 & $93,62 \%$ & 22.981 & 10.022 & $-56,39 \%$ & 93.850 & 147.239 & $56,89 \%$ \\
\hline R. ALTA & 1.501 & 4.026 & $168,22 \%$ & 14.527 & 7.661 & $-47,26 \%$ & 16.028 & 11.687 & $-27,08 \%$ \\
\hline REGIÃO & 90.090 & 175.695 & $95,02 \%$ & 138.843 & 79.945 & $-42,42 \%$ & 222.933 & 255.640 & $14,67 \%$ \\
\hline ESTADO & 3.553 .006 & 6.994 .134 & $96,85 \%$ & 3.111 .885 & 2.141 .345 & $-31,19 \%$ & 6.664 .891 & 9.135 .479 & $37,07 \%$ \\
\hline
\end{tabular}

Fonte: IBGE - Censo Demográfico do RS

$\mathrm{Na}$ tabela número 02, verifica-se que o PIB da região, apesar de apresentar um aumento de $47,28 \%$, cresceu menos do que o apresentado pelo Estado. Também, percebe-se que o município de Ronda Alta apresenta uma variação negativa, neste mesmo período.

Tabela 02 - Evolução do Produto Interno Bruto no período de 1984 a 1993 (US\$ milhões)

\begin{tabular}{|l|r|r|r|r|}
\hline ITENS & 1.984 & 1.990 & 1.993 & Var. 90/94 \\
\hline PASSO FUNDO & 357,67 & 489,69 & 669,20 & $87,10 \%$ \\
\hline RONDA ALTA & 36,92 & 16,51 & 25,43 & $-31,12 \%$ \\
\hline REGIÃO & 601,57 & 657,72 & 885,97 & $47,28 \%$ \\
\hline ESTADO & $24.040,15$ & $31.743,03$ & $38.632,17$ & $60,70 \%$ \\
\hline
\end{tabular}

Fonte: ANÁLISE/ Faculdade de Ciências Políticas e Econômicas - PUCRS 
Os dados apresentados nestas tabelas indicam um progressivo empobrecimento da economia do município de Ronda Alta, em função da redução da população total, acompanhado por um crescimento excessivo da população urbana e uma redução, significativa, do PIB municipal. Outro fator que deve ser levado em consideração, é o fato de que, quando ocorre uma redução da população total, significa dizer que, além da economia perder parcela da sua força de trabalho, a qual poderia gerar riquezas para a sociedade, perde-se, também, uma parcela significativa de recursos financeiros gerados na economia da região, os quais passam a ser investidos em outras regiões, pela falta de vantagens comparativas ou por absoluta falta de oportunidades de negócios

$\mathrm{Na}$ agricultura, conforme a tabela 03 , observa-se uma tendência de aumento na concentração da terra, na medida em que ocorreu, na região, uma diminuição do número total de unidades agropecuárias, com área entre 20 a 50 hectares, enquanto que os demais extratos mostram crescimento. Isto também pode ser verificado, a partir dos dados da região, na medida em que aumentou o número de unidades com área até 20 hectares, bem como a área ocupada por este extrato. Por outro lado, seja por desmembramentos sucessórios, seja pela necessidade da venda de parte da sua área, ocorreu, no período de 1970 a 1985, uma pequena redução na área total das unidades, porém, uma grande redução na área total ocupada pelas propriedades de 20 a 50 hectares.

Tabela 03 - Evolução do número de unidades de produção agropecuária no período de 1970 a 1985 conforme os extratos de área. (continua ...)

\begin{tabular}{|c|c|c|c|c|c|c|c|c|c|}
\hline \multirow{2}{*}{$\begin{array}{l}\text { ITENS } \\
\text { ANOS } \\
\end{array}$} & \multicolumn{3}{|c|}{ até 20} & \multicolumn{3}{|c|}{ de 20 a 50} & \multicolumn{3}{|c|}{ de 50 a 100} \\
\hline & 1.970 & 1.985 & Var. $70 / 85$ & 1.970 & 1.985 & Var. 70/85 & 1.970 & 1.985 & Var. $70 / 85$ \\
\hline P. FUNDO & 1.735 & 1.031 & $-40,58 \%$ & 877 & 608 & $-30,67 \%$ & 321 & 301 & $-6,23 \%$ \\
\hline R ALTA & 1.817 & 1.872 & $3,03 \%$ & 492 & 443 & $-9,96 \%$ & 43 & 78 & $81,40 \%$ \\
\hline REGIÃO & 14.145 & 15.323 & $8,33 \%$ & 6.040 & 4.983 & $-17,50 \%$ & 839 & 908 & $8,22 \%$ \\
\hline ESTADO & 321.293 & 317.241 & $-1,26 \%$ & 126.849 & 113.108 & $-10,83 \%$ & 30.446 & 30.768 & $1,06 \%$ \\
\hline
\end{tabular}

Fonte: IBGE - Censo Agropecuário do RS 
Tabela 03 - Evolução do número de unidades de produção agropecuária no período de 1970 a 1985 conforme os extratos de área. ( ... continuação)

\begin{tabular}{|l|r|r|r|r|r|r|}
\hline ITENS & \multicolumn{3}{|c|}{ mais de 100 ha } & \multicolumn{2}{c|}{ TOTAL } \\
\hline ANOS & 1.970 & 1.985 & Var. $70 / 85$ & 1.970 & 1.985 & Var. $70 / 85$ \\
\hline PASSO FUNDO & 378 & 351 & $-7,14 \%$ & 3.311 & 2.291 & $-30,81 \%$ \\
\hline RONDA ALTA & 68 & 71 & $4,41 \%$ & 2.420 & 2.464 & $1,82 \%$ \\
\hline REGIÃO & 619 & 662 & $6,95 \%$ & 21.643 & 21.876 & $1,08 \%$ \\
\hline ESTADO & 33.062 & 35.462 & $7,26 \%$ & 511.650 & 496.579 & $-2,95 \%$ \\
\hline
\end{tabular}

Fonte: IBGE - Censo Agropecuário do RS

Tabela 04 - Evolução da área total das unidades de produção agropecuária no período de 1970 a 1985 conforme os extratos de área. (continua ...)

\begin{tabular}{|c|c|c|c|c|c|c|c|c|c|}
\hline ITENS & \multicolumn{3}{|c|}{ até 20 ha } & \multicolumn{3}{|c|}{20 a 50 ha } & \multicolumn{3}{|c|}{50 a $100 \mathrm{ha}$} \\
\hline ANOS & 1.970 & 1.985 & $\operatorname{Var} .70 / 85$ & 1.970 & 1.985 & Var. $70 / 85$ & 1.970 & 1.985 & Var. $70 / 85$ \\
\hline P. FUNDO & 15.249 & 9.768 & $-35,94 \%$ & 25.919 & 19.007 & $-26,67 \%$ & 22.199 & 20.356 & $-8,30 \%$ \\
\hline R. ALTA & 17.060 & 18.055 & $5,83 \%$ & 13.025 & 12.726 & $-2,30 \%$ & 2.639 & 5.062 & $91,82 \%$ \\
\hline REGIÃO & 129.933 & 139.491 & $7,36 \%$ & 170.530 & 142.313 & $-16,55 \%$ & 53.782 & 59.141 & $9,96 \%$ \\
\hline ESTADO & 2.817 .722 & 2.734 .296 & $-2,96 \%$ & 3.685 .854 & 3.331 .014 & $-9,63 \%$ & 2.049 .507 & 2.075 .575 & $1,27 \%$ \\
\hline
\end{tabular}

Fonte: IBGE - Censo Agropecuário do RS

Tabela 04 - Evolução da área total das unidades de produção agropecuária no período de 1970 a 1985 conforme os extratos de área. ( ... continuação)

\begin{tabular}{|c|c|c|c|c|c|c|}
\hline ITENS & \multicolumn{3}{|c|}{ mais de 100 ha } & \multicolumn{3}{|c|}{ TOTAL } \\
\hline ANOS & 1.970 & 1.985 & Var. $70 / 85$ & 1.970 & 1.985 & Var. $70 / 85$ \\
\hline PASSO FUNDO & 110.510 & 114.418 & $3,54 \%$ & 173.877 & 163.549 & $-5,94 \%$ \\
\hline RONDA ALTA & 27.658 & 22.491 & $-18,68 \%$ & 60.382 & 58.334 & $-3,39 \%$ \\
\hline REGIÃO & 208.633 & 220.933 & $5,90 \%$ & 562.878 & 561.878 & $-0,18 \%$ \\
\hline ESTADO & 15.254 .098 & 15.680 .804 & $2,80 \%$ & 23.807 .181 & 23.821 .689 & $0,06 \%$ \\
\hline
\end{tabular}

Fonte: IBGE - Censo Agropecuário do RS 
A análise da produção dos principais produtos agropecuários demonstra que a atividade soja, conforme a tabela 05, apresentou um crescimento significativo da área plantada, bem como da produção obtida no período de 1970 a 1992, no município de Ronda Alta e na Região. Entretanto, este crescimento é inferior ao observado no Estado. O mesmo não ocorre com a variação da produtividade física (toneladas por hectare), neste mesmo período, uma vez que o rendimento físico na região da associação, foi superior ao observado no estado do Rio Grande do Sul. Estes dados podem ser visualizados nas tabelas 05 e 06.

Tabela 05 - Evolução da área plantada (ha) e da produção (toneladas) de soja no período de 1970 a 1992.

\begin{tabular}{|l|r|r|r|r|r|r|}
\hline ITENS & \multicolumn{3}{|c|}{ AREA - ha } & \multicolumn{2}{c|}{ PROD. - ton. } \\
\hline ANOS & 1.970 & 1.992 & Var. $70 / 92$ & 1.970 & 1.992 & Var. $70 / 92$ \\
\hline PASSO FUNDO & 58.062 & 81.500 & $40,37 \%$ & 53.134 & 171.150 & $222,11 \%$ \\
\hline RONDA ALTA & 17.929 & 24.000 & $33,86 \%$ & 14.232 & 50.400 & $254,13 \%$ \\
\hline REGIÃO & 157.701 & 224.900 & $42,61 \%$ & 122.615 & 461.290 & $276,21 \%$ \\
\hline ESTADO & 1.600 .131 & 2.876 .598 & $79,77 \%$ & 1.295 .149 & 5.629 .537 & $334,66 \%$ \\
\hline
\end{tabular}

Fonte: IBGE - Censo Agropecuário do RS

Tabela 06 - Evolução do rendimento físico da soja no período de 1970 a 1992.

\begin{tabular}{|l|r|r|r|r|}
\hline ANOS & 1.970 & 1.980 & 1.992 & Var. 70/92 \\
\hline PASSO FUNDO & 0,92 & 1,66 & 2,10 & $129,48 \%$ \\
\hline RONDA ALTA & 0,79 & 1,61 & 2,10 & $164,55 \%$ \\
\hline REGIÃO & 0,78 & 1,51 & 2,05 & $163,80 \%$ \\
\hline ESTADO & 0,81 & 1,36 & 1,96 & $141,78 \%$ \\
\hline
\end{tabular}

Fonte: IBGE - Censo Agropecuário do RS 
A análise da produção de trigo no período de 1970 a 1990, conforme as tabelas 07 e 08, apresentadas a seguir, indica uma evolução diferente da atividade soja, uma vez que a produção obtida (em toneladas), mostra uma queda, neste período, em Ronda Alta e Região. Cabe ressaltar que a produção de trigo, nesta região, apresenta um comportamento semelhante ao ocorrido no Estado do Rio Grande do Sul. Os dados sobre a área plantada e produção colhida, neste período, demonstram a elevação da produtividade física da atividade tritícola na Região. Porém, este crescimento foi inferior ao observado no Estado.

Tabela 07 - Evolução da área plantada (ha) e da produção (toneladas) de trigo no período de 1970 a 1990.

\begin{tabular}{|l|r|r|r|r|r|r|}
\hline ITENS & \multicolumn{3}{|c|}{ ÁREA - ha } & \multicolumn{2}{c|}{ PRODUÇÃo - $t$. } \\
\hline ANOS & 1.970 & 1.990 & Var. $70 / 90$ & 1.970 & 1.990 & Var. $70 / 90$ \\
\hline PASSO FUNDO & 66.366 & 12.500 & $-81,17 \%$ & 68.729 & 18.750 & $-72,72 \%$ \\
\hline RONDA ALTA & 10.549 & 10.500 & $-0,46 \%$ & 11.045 & 9.450 & $-14,44 \%$ \\
\hline REGİ̃O & 121.739 & 73.550 & $-39,58 \%$ & 114.844 & 81.175 & $-29,32 \%$ \\
\hline ESTADO & 1.672 .351 & 988.158 & $-40,91 \%$ & 1.599 .067 & 1.168 .628 & $-26,92 \%$ \\
\hline
\end{tabular}

Fonte: IBGE - Censo Agropecuário do RS

Tabela 08 - Evolução do rendimento físico (toneladas por hectare) do trigo no período de 1970 a 1990.

\begin{tabular}{|l|r|r|r|r|}
\hline ANOS & 1.970 & 1.980 & 1.990 & Var. $70 / 90$ \\
\hline PASSO FUNDO & 1,04 & 0,84 & 1,50 & $44,84 \%$ \\
\hline RONDA ALTA & 1,05 & 0,92 & 0,90 & $-14,04 \%$ \\
\hline REGIÃO & 0,94 & 0,83 & 1,10 & $16,99 \%$ \\
\hline ESTADO & 0,96 & 0,74 & 1,18 & $23,68 \%$ \\
\hline
\end{tabular}

Fonte: IBGE - Censo Agropecuário do RS 
Destaca-se o fato de que, tanto a atividade de soja quanto a atividade de trigo constituem lavouras nas quais é utilizada uma alta tecnologia, em termos de insumos, bem como ha utilização intensa de máquinas agrícolas. Este fato exclui parte dos trabalhadores, do seu processo de produção, na medida em que necessita de uma quantidade menor de trabalho humano.

As tabelas 09 e 10, mostram dados sobre a evolução, durante o período de 1970 a 1993, da atividade milho, na Região da Associação, bem como no Estado do Rio Grande do Sul. Conforme estes dados, pode-se observar uma redução significativa na área plantada, com a atividade, na região em estudo. Analisando os dados relativos à evolução do volume produzido, em toneladas, observa-se que, neste período, ocorreu, apesar da significativa redução na área plantada, um crescimento de $23 \%$ no volume produzido. Estes dados demonstram que ocorreu, na região, uma elevação no rendimento físico desta atividade que é superior ao observado no Estado.

Tabela 09 - Evolução da área plantada (ha) e da produção (toneladas) de milho no período de 1970 a 1993.

\begin{tabular}{|l|r|r|r|r|r|r|}
\hline ITENS & \multicolumn{3}{|c|}{ ÁREA - ha } & \multicolumn{3}{c|}{ PROD - ton. } \\
\hline ANOS & 1.970 & 1.993 & Var. $70 / 93$ & 1.970 & 1.993 & Var. $70 / 93$ \\
\hline PASSO FUNDO & 13.405 & 6.000 & $-55,24 \%$ & 13.210 & 19.800 & $49,89 \%$ \\
\hline RONDA ALTA & 13.470 & 5.500 & $-59,17 \%$ & 18.471 & 19.800 & $7,20 \%$ \\
\hline REGIÃO & 125.900 & 65.850 & $-47,70 \%$ & 173.879 & 213.864 & $23,00 \%$ \\
\hline ESTADO & 1.870 .469 & 1.741 .492 & $-6,90 \%$ & 2.230 .302 & 4.605 .268 & $106,49 \%$ \\
\hline
\end{tabular}

Fonte: IBGE - Censo Agropecuário do RS

Tabela 10 - Evolução do rendimento físico (toneladas por hectare) do milho no período de 1970 a 1993.

\begin{tabular}{|l|r|r|r|r|}
\hline ANOS & 1.970 & 1.980 & 1.993 & Var. 70/93 \\
\hline PASSO FUNDO & 0,99 & 1,61 & 3,30 & $234,87 \%$ \\
\hline RONDA ALTA & 1,37 & 1,74 & 3,60 & $162,53 \%$ \\
\hline REGIÃO & 1,38 & 1,60 & 3,25 & $135,16 \%$ \\
\hline ESTADO & 1,19 & 1,56 & 2,64 & $121,78 \%$ \\
\hline
\end{tabular}

Fonte: IBGE - Censo Agropecuário do RS 
A análise dos dados relativos à produção leiteira mostra um quadro semelhante ao da atividade de milho. Conforme as tabelas 11 e 12, podese verificar que, na Região da Associação, o número de vacas ordenhadas, no período de 1970 a 1992, cresceu em escala inferior ao observado no total do Estado. Fato idêntico ocorreu com a produção leiteira. Como conseqüência, o rendimento físico, medido em 1.000 litros/vaca/ano, apresentou um crescimento inferior, na região, que o observado no Rio Grande do Sul.

Tabela 11 - Evolução do número de vacas ordenhadas e da produção leiteira (1000 litros) no período de 1970 a 1992.

\begin{tabular}{|l|r|r|r|r|r|r|}
\hline ITENS & \multicolumn{3}{|c|}{ VACAS ORD. } & \multicolumn{2}{c|}{ PROD. (1000 1) } \\
\hline ANOS & 1.970 & 1.992 & Var. $70 / 92$ & 1.970 & 1.992 & Var. 70/92 \\
\hline PASSO FUNDO & 5.488 & 9.300 & $69,46 \%$ & 6.969 & 13.950 & $100,17 \%$ \\
\hline RONDA ALTA & 2.395 & 2.800 & $16,91 \%$ & 2.586 & 3.281 & $26,88 \%$ \\
\hline REGIÃO & 26.179 & 35.656 & $36,20 \%$ & 29.314 & 48.029 & $63,84 \%$ \\
\hline ESTADO & 815.206 & 1.216 .808 & $49,26 \%$ & 778.478 & 1.600 .469 & $105,59 \%$ \\
\hline
\end{tabular}

Fonte: IBGE - Censo Agropecuário do RS

Tabela 12 - Evolução da produtividade física (1000 litros/vaca/ano) da atividade leiteira de 1970 a 1992.

\begin{tabular}{|l|r|r|r|r|}
\hline ANOS & 1.970 & 1.980 & 1.992 & Var. 70/92 \\
\hline PASSO FUNDO & 1,27 & 1,67 & 1,50 & $18,12 \%$ \\
\hline RONDA ALTA & 1,08 & 1,27 & 1,17 & $8,52 \%$ \\
\hline REGIÃO & 1,12 & 1,46 & 1,35 & $20,30 \%$ \\
\hline ESTADO & 0,95 & 1,34 & 1,32 & $37,74 \%$ \\
\hline
\end{tabular}

Fonte: IBGE - Censo Agropecuário do RS

A análise da evolução do número de bovinos, na região, indica que ocorreu uma redução, durante a década de 80 . O mesmo não ocorreu 
no Estado, onde, inclusive, ocorreu um incremento na atividade. Já, a análise da atividade suína indica uma queda significativa no número de animais, principalmente, na região em estudo. A redução também ocorreu no Estado, porém, em menor escala. Estes dados podem ser visualizados na tabela número 13 , apresentada, a seguir.

Tabela 13 - Evolução do número de bovinos e de suínos no período de 1970 a 1992.

\begin{tabular}{|l|r|r|r|r|r|r|}
\hline ITENS & \multicolumn{3}{|c|}{ BOVINOS } & \multicolumn{3}{c|}{ SUÍNOS } \\
\hline ANOS & 1.970 & 1.992 & Var. 70/92 & 1.970 & 1.992 & Var. 70/92 \\
\hline PASSO FUNDO & 43.390 & 35.916 & $-17,23 \%$ & 26.263 & 20.143 & $-23,30 \%$ \\
\hline RONDA ALTA & 17.041 & 15.250 & $-10,51 \%$ & 38.168 & 22.700 & $-40,53 \%$ \\
\hline REGIÃO & 174.283 & 163.571 & $-6,15 \%$ & 415.889 & 199.947 & $-51,92 \%$ \\
\hline ESTADO & 12.305 .119 & 13.905 .291 & $13,00 \%$ & 5.851 .507 & 3.929 .082 & $-32,85 \%$ \\
\hline
\end{tabular}

Fonte: IBGE - Censo Agropecuário do RS

De acordo com a tabela 14 , verifica-se que, no período de 1970 a 1992, ocorreu uma elevação no número de aves, na região em estudo, bem como no Estado do Rio Grande do Sul; no entanto, o desenvolvimento da atividade ocorreu, de forma muito mais intensa no Estado do que na região. No município de Ronda Alta, neste período, ocorreu uma redução no número de aves. Por outro lado, a atividade ovina apresentou, neste mesmo período, uma redução semelhante no número de animais, tanto na região como no Estado. No município de Ronda Alta, a atividade apresentou uma queda maior no número de animais.

Tabela 14 - Evolução do número de aves e de ovinos no período de 1970 a 1992.

\begin{tabular}{|l|r|r|r|r|r|r|}
\hline ITENS & \multicolumn{3}{|c|}{ AVES } & \multicolumn{3}{c|}{ OVINOS } \\
\hline ANOS & 1.970 & 1.992 & Var. $70 / 92$ & 1.970 & 1.992 & Var. $70 / 92$ \\
\hline PASSO FUNDO & 139.982 & 537.350 & $283,87 \%$ & 6.084 & 6.630 & $8,97 \%$ \\
\hline RONDA ALTA & 116.869 & 113.540 & $-2,85 \%$ & 1.213 & 900 & $-25,80 \%$ \\
\hline REGIÃO & 1.127 .392 & 1.596 .074 & $41,57 \%$ & 14.481 & 11.900 & $-17,82 \%$ \\
\hline ESTADO & 29.164 .199 & 109.663 .151 & $276,02 \%$ & 12.157 .357 & 10.163 .929 & $-16,40 \%$ \\
\hline
\end{tabular}

Fonte: IBGE - Censo Agropecuário do RS 
De acordo com os dados apresentados, a respeito da região, na qual se localiza a AANRA, pode-se observar que, juntamente com uma tendência muito forte de urbanização e de progressivo empobrecimento, caracterizado, mais especificamente, no município de Ronda Alta, ocorreu, nas últimas décadas, a adoção, por parte da maioria da população que permanece na agropecuária, do modelo de lavouras do tipo empresarial. Este modelo sabidamente objetiva a produção, em larga escala, de produtos destinados principalmente, para a exportação. Com isto, as atividades ditas de subsistência têm a sua produção consideravelmente diminuída. Sabe-se, também, que as produções do tipo empresarial, para terem competitividade no mercado, necessitam, geralmente, de uma alta tecnologia e, por isso, tendem a apresentar altos custos de produção que, por sua vez, deveriam ser absorvidos pela escala de produção, ou seja, necessitam de grandes extensões de terra.

Os dados demonstram, ainda, uma diminuição considerável na área plantada de milho e no número de suínos. Além disto, o incremento da atividade leiteira, seja em número de vacas ordenhadas, seja em litros de leite produzidos, apresentaram um crescimento inferior ao observado no estado do Rio Grande do Sul. O mesmo ocorreu com a atividade de bovinos e de aves. Reconhecidamente, são estas as atividades que necessitam de uma quantidade maior de mão-de-obra. A partir disto, podemos explicar, pelo menos em parte, a tendência crescente do êxodo rural e todos os problemas decorrentes deste processo.

Todos estes dados nos demonstram que o modelo de desenvolvimento da agricultura brasileira introduzido no Brasil, a partir do final da década de 50 , baseado no processo de modernização da agricultura foi, na prática, adotado, também, nesta região, bem como, especificamente no município de Ronda Alta. Como Conseqüência, observa-se o aparecimento de uma série de dificuldades para a manutenção, principalmente das micro e pequenas propriedades. 
A primeira dificuldade diz respeito à competitividade destas propriedades num mercado que se apresenta cada vez mais concorrencial e onde a eficiência e a eficácia das atividades são fundamentais. A segunda dificuldade, relaciona-se com a sobra de mão-de-obra, na medida em que as atividades passam a ser desenvolvidas a partir de novas e modernas tecnologias, as quais necessitam de uma quantidade menor deste fator de produção

Concluindo, pode-se afirmar que as Associações de Produção Coletiva surgem, também, para se constituirem numa alternativa para estes pequenos agricultores, no sentido da sua manutenção no processo de produção e como forma de melhorar, ou até de viabilizar, a sua concorrência, neste mercado, que se apresenta, com o passar dos anos, cada vez mais competitivo. 


\section{O PCP COMO INSTRUMENTO DE TOMADA DE DECISÃO NA AANRA}

Esta parte do trabalho tem por objetivo apresentar um relato e uma análise sucinta dos dados levantados, através das entrevistas realizadas junto aos associados da AANRA. Estes dados dizem respeito à situação atual do PCP - Planejamento e Controle da Produção, na associação dos Agricultores de Nova Ronda Alta.

Em termos conceituais, podemos definir o associativismo como sendo o congregacionamento de um grupo de indivíduos pertencentes a um mesmo grupo social, com o objetivo da representação e defesa de seus interesses comuns. Assim, a associação, no seu conjunto, pode ser entendida como uma propriedade agrícola qualquer que reúne uma quantidade maior de determinados fatores de produção, principalmente de uma quantidade maior de trabalho. Em outros termos, ela se torna uma propriedade agrícola com um poder de barganha maior que as propriedades individuais que a compōem. O pequeno produtor também teria estas condições?

Segundo os associados, pode ser que sim, mas eles apresentam vantagens no que tange, principalmente, aos investimentos. $A$ união de mais de uma pequena propriedade, torna-os mais fortes e com um poder de barganha muito maior $e$, em função disto, tem condições de fazer o que, em muitos casos, o pequeno agricultor, isoladamente, não teria condições de fazer.

Alem disto, a associação tem outras vantagens quando comparada à pequena produção familiar. Estas vantagens dizem respeito à questão da produção em escala, na medida em que, nas compras em grandes quantidades, se consegue um desconto maior $e$, por outro lado, pela quantidade produzida, consegue-se preços melhores na venda do produto. Por outro lado, a associação também enfrenta os mesmos problemas que a pequena produção. 
Estes problemas dizem respeito à falta de uma política agrícola, bem definida e segura, que possa atender às reivindicações dos produtores, bem como, à falta de mercado e de preços mínimos, para boa parte dos produtos.

A associação, atualmente, está estruturada a partir de seis setores diferentes, os quais, no seu conjunto, constituem a unidade da entidade. Os setores são:

1) Setor leiteiro

Este setor é administrado pelas. A produção deste setor destina-se à satisfação das necessidades das famílias dos membros da associação.

2) Setor de costura

Este setor também é administrado pelas mulheres. Parte da produção deste setor destina-se à satisfação das necessidades de todos os membros da associação. Boa parte da produção do setor de costuras destina-se a suprir uma demanda de uma fábrica localizada no município de Ronda Alta.

3) Setor bar

Este setor está sob a responsabilidade de uma família. Localiza-se no distrito do Passo, interior de Ronda Alta. Tem por finalidade atender aos associados, bem como a outras pessoas.

4) Setor de construção civil

Este é o setor responsável pelas edificações, na associação. Como tal, tem por objetivo a construção e manutenção das casas dos associados, bem como das demais construções necessárias para o bom andamento das atividades da entidade. 
5) Setor de suínos

É o setor responsável pela produção da atividade de suínos. Constitui-se num dos setores mais importantes da associação, na medida em que é responsável por uma parcela significativa das receitas da entidade.

6) Setor agricultura

Juntamente com o setor de suínos, representa a atividade mais importante da associação, na medida em que congrega o maior número de pessoas, bem como produz boa parte da renda da associação.

Pelas intervenções dos associados, percebe-se que a atividade mais importante, na associação, é a de criação de suínos, que se constitui numa atividade típica de pequena propriedade e que necessita de uma quantidade maior de força de trabalho. A grande questão colocada diz respeito ao tipo de atividade escolhida para ser desenvolvida na associação, bem como em relação às variáveis que necessitam ser levadas em consideração.

Quanto a isto, a colocação dos associados é que a decisão inicial era a produção de frangos. Para tanto, obteve-se um recurso da Europa. Em relação a esta decisão, as seguintes questões, segundo os associados, merecem ser analisadas. "A atual instalação é para 3 mil frangos. Foi pensada e construída, produziu-se, no início, e o resultado? Não foi feita uma pesquisa de mercado. Vender para quem? Comprova-se, assim, mais uma vez, que é preciso planejar antes de se efetuar qualquer empreendimento" ${ }^{1}$. Hoje, esta mesma instalação está sendo reaproveitada na produção de suínos, pois esta atividade está mais perto da assistência técnica e do mercado comprador. Estes dados reforçam a tese de que é de importância fundamental, para o sucesso da associação, o uso de instrumentos eficientes e eficazes de planejamento e de controle, para o processo decisório das atividades, e da própria associação.

${ }^{1}$ Depoimento dos próprios associados da AANRA 
O processo de tomada de decisão, na associação, ocorre em dois diferentes níveis. A diferenciação dá-se, a partir da importância estratégica da decisão, para a associação. No primeiro nível, incluem-se aquelas decisões diárias sobre o processo produtivo da associação. Em outros termos, significa dizer que, quando as decisões envolvem variáveis que dizem respeito às operações diárias dos setores, o responsável pelo setor é quem deve tomar a decisão, ou seja, quando se trata de questões corriqueiras, por exemplo, alguém precisa de ajuda de outro setor ou quando é necessário decidir sobre o tipo de tarefa a ser desenvolvida, entre outras, é o próprio responsável pelo setor que deve tomar a decisão.

No segundo nivel, englobam-se as decisões estratégicas que dizem respeito à associação como um todo. Neste caso, as decisões são encaminhadas coletivamente pela assembléia, a qual se reúne para uma ampla discussão e análise da situação. A partir disto, a decisão é tomada por maioria simples dos sócios. Isto significa dizer que, quando se trata de uma decisão mais importante a ser tomada, por exemplo, a compra de uma vaca leiteira, a questão é levada para uma reunião, com a presença de todos. Quando a questão que está em jogo diz respeito a investimentos, todos se reúnem para tomar uma decisão conjunta.

Portanto, para cada setor, existem tomadas de decisão em conjunto, quando se tratam de questões mais amplas e dizem respeito a negócios, compra ou venda e, quando se referem mais ao dia a dia, estas são tomadas pelo próprio responsável. Na verdade, quando a decisão envolver a associação como um todo, investimentos, estrutura, a decisão é tomada por todos, no seu conjunto. Quando é uma coisa mais do setor, operacional, de fazer ou não fazer uma atividade, é o setor responsável pela decisão.

Numa assembléia, quando a questão que está em jogo é o investimento, aí todos se reúnem, discutem a proposta de investir, é feito um 
planejamento em torno do projeto do novo investimento. Após discutido e planejado o novo empreendimento, toma-se uma decisão e, em seguida, esta é executada.

No entender da associação, administrar é fazer o dia a dia, é planejar, controlar e executar, ou seja, é fazer funcionar o conjunto das atividades da associação, para o alcance dos seus objetivos. Segundo os associados, administrar é tomar a decisão. Depois de planejado e controlado tem-se a certeza que este é o caminho a ser seguido. A partir disto toma-se a decisão e se executa o planejado. $O$ passo seguinte é o controle, que tem por objetivo manter as atividades dentro daquilo que foi planejado, bem como corrigir eventuais erros do próprio processo de planejamento das atividades e do conjunto da associação.

Segundo os associados, planejar é prever. Um dos membros da associação deixa bem claro que o planejamento é algo de um futuro próximo, de uma safra a outra safra, de um lote para outro lote, e entre esses períodos ocorre o planejamento, para que os objetivos sejam alcançados, no período seguinte. Fica claro, também, que é necessário o planejamento de longo prazo, ou seja, também é importante, para o sucesso do empreendimento associativo, a determinação de metas e de objetivos para períodos mais longos e não apenas a previsão de um futuro próximo, pois isto faz com que o processo de planejamento seja algo constante e contínuo, no qual as decisões de longo prazo passam a ser revistas, continuamente, fazendo-se os ajustes necessários para 0 bom andamento das operações, na associação.

Mesmo com estas colocações, percebe-se que a atividade de planejamento da produção, na associação, está longe do que deveria ser, na medida em que, atualmente, não existe uma prática ordenada de planejamento. $O$ que se faz na, verdade, é um conjunto de discussões acerca das atividades que 
podem ser desenvolvidas na associação, não existindo, contudo, um levantamento sistemático de dados que possam ser utilizados neste processo.

Para a associação, o controle é manter as coisas em dia, é não perder as rédeas. Segundo as colocações dos associados, o processo de controle é a forma pela qual a entidade verifica a viabilidade e a eficiência do planejamento e do próprio processo decisório.

O primeiro tipo de controle observado na associação é o que os associados chamam de prestação de contas. Nos setores de costura, leite e bar ocorre uma prestação de contas mensal. Esta prestação de contas ocorre, a partir das anotações efetuadas no livro caixa. Estas anotações são realizadas quando ocorre algum tipo de movimentação financeira. Neste caso, verifica-se a ocorrência ou não de "lucro". Nos setores de suínos e de agricultura, a prestação de contas ocorre no final de cada período de comercialização da produção. Convém ressaltar que o "lucro" corresponde, para os associados da AANRA, à diferença entre 0 volume total de receitas e o volume total de despesas, em valores monetários anotados durante o período de análise.

Com o objetivo da socialização das informações entre os associados, cada responsável pelos setores distribui os resultados, a partir de uma matriz mimeografada, a qual contém o respectivo "lucro" ou o "prejuízo" ocorrido, naquele período em análise. Segundo os associados, há necessidade de que todos estejam cientes de como se encontra economicamente a associação. $O$ que se percebe, com isto, é a preocupação com a transparência das operações realizadas, em cada um dos setores da associação.

Neste livro caixa, ocorre um balanço dos resultados obtidos, durante $O$ ano. Existe um controle mensal. $O$ problema que a associação está enfrentando é que só existe um controle, mais direto e acompanhado por técnicos, no setor de criação e produção de suínos. Por exemplo, no setor do 
suíno, onde existe um maior controle, são feitas todas as anotações, desde o cio da leitoa até a venda dos suínos. Durante esse período ocorre o controle da alimentação, leitões nascidos, período de amamentação; enfim, todos os controles possiveis, tudo visando objetivos: saber, se realmente a leitoa serve para a procriação, se existe eficiência na questão do trato, entre outros. Ainda, segundo os associados, estes controles têm como função básica a constatação da eficiência e da eficácia das ações desenvolvidas e a observação da ocorrência de variações na renda da associação.

Os associados justificam todo esse controle, porque a maioria dos pequenos e médios produtores não possuem um controle rígido $e$, segundo eles, é esse controle que thes assegura que, realmente, estão ganhando dinheiro. Sem um controle, acaba-se perdendo a noção de quanto se está investindo. Além disso, o controle proporciona visualizar as variações entre meses de alta e baixa e variações entre lotes e seu aproveitamento, no seu conjunto. Estes controles também dão condições de se verificar e dizer se os problemas são estes e porque se apresentam assim. Observa-se, porém, que, mesmo nestas atividades, os controles e o processo de planejamento da produção, se resumem a aspectos técnicos. Os econômicos e os financeiros acabam sendo ignorados pelos próprios associados, na medida em que não os utilizam no processo decisório.

Assim, podemos identificar dois objetivos diferentes dos controles. O primeiro objetivo é o de prestação de contas, internamente, no setor, bem como, para a associação, como um todo, além de ser uma forma de manter estas contas em dia. Como segundo objetivo, tem-se que os controles servem para tomar a decisão certa, verificar se estão sendo eficientes, se estão tendo produtividade, se estão tendo problemas técnicos e operacionais. Estas informações produzidas pelo processo de controle são repassadas aos demais associados, na assembléia. Geralmente, às quartas-feiras, todos se reúnem e discutem os problemas ocorridos durante a semana, o que foi feito, e o que 
precisa ser feito para a semana seguinte: enfim, programam a semana. Além dessas coisas corriqueiras, discute-se, como já foi mencionado, projetos, empreendimentos, investimentos novos, entre outros.

Nos setores de suínos e de leite, as planilhas de controle foram introduzidas pelos técnicos que acompanham e orientam estas atividades. Os instrumentos de controle são fichas, que foram adquiridas com os técnicos, diante da necessidade de se ter um controle assíduo e bem feito, com o objetivo de obter os melhores e os mais confiáveis dados a respeito do setor. No setor leiteiro, os controles foram introduzidos pelos técnicos da EMATER que estão prestando a assistência técnica.

Nos demais setores, os instrumentos de controle praticamente inexistem formalmente. $O$ que existe são algumas anotações que relacionam os dados mais expressivos, em termos de valores financeiros, tais como os investimentos efetuados nas diferentes atividades. Falta, porém, um sistema de controle mais sistemático acerca do desenvolvimento das diferentes atividades desenvolvidas. Isto pode ser observado, a partir da seguinte afirmativa dos associados. "Nos outros setores, por exemplo no bar e na lavoura, não há um controle mais rígido, mas existe um controle de quanto se investiu qual é o retorno". Contudo, os associados afirmam saber a situação atual dos setores.

Mas o que chama atenção é a preocupação, por parte da associação, no que diz respeito ao controle dos demais setores. Para ela, este é o momento de se implantar um controle eficiente, capaz de demonstrar as lacunas, onde se faz necessária maior atenção. Por exemplo, no melhoramento das atividades, produzir com menos custos, aumentar a produtividade, entre outros, com o objetivo de aumentar a sua competitividade no mercado local e regional. 
A associação tem certeza de que, no mais breve tempo possivel, terá que tomar uma decisão de implementar um conjunto de instrumentos e, dessa forma, averiguar os resultados, que poderão ser melhores com este sistema, que devem levar o setor à racionalização e à competitividade da produção.

Outra questão, que começa a ser discutida na associação, é o controle dos custos fixos, incorridos com o processo de produção. Segundo os associados, foi com o tempo de serviço que se verificou a necessidade destes instrumentos. Este capital que está em jogo na hora da produção, e com o tempo vai se depreciando, chegará a um ponto quando deverá ser substituído por outro. Outro fator que a associação levanta diz respeito ao custo de oportunidade. Perceberam, com o tempo de serviço e com atividades que não deram bons resultados, que um capital empregado num setor poderá alcançar resultados melhores em outro setor, o que conduz a associação, cada vez mais, para um planejamento, uma discussão mais profunda para os futuros investimentos.

Concretamente, as informações produzidas pelos controles, passam a ser a base do processo de decisão acerca do planejamento de novos investimentos, na associação. Por exemplo, o novo empreendimento feito, recentemente, é fruto de informações, levantadas durante um ano e meio, juntamente com os técnicos. Estas informaçōes consistem no aproveitamento dos recursos próprios, genética do suíno, variação dos juros, custos por unidade, lucros ou ganhos, mercado comprador, etc. São vários fatores que são levantados e acompanhados, durante um período, com o objetivo de chegar a uma conclusão, bem clara, de que o novo investimento é válido e tem retorno certo.

Este processo de planejamento e de controle, também permite, de certa forma, otimizar o uso dos recursos disponíveis em atividades que proporcionem melhores retornos nos períodos de "alta" e de "baixa", ou seja, 
o planejamento e o controle permitem adotar uma estratégia para a saída desses períodos de "baixa" e produzir, em maior escala, atividades alternativas e que aproveitem melhor os produtos produzidos nas atividade normais da associação. Assim, em períodos de crise, um eficiente sistema de planejamento e controle da produção pode recomendar um processo de verticalização da produção, com o objetivo de agregar valor aos produtos que são a base do processo de produção.

Os membros da associação ressaltam a importância da competitividade do setor suíno. Tem sempre em mente que o preço é o responsável pela queda dos lucros. Mas deve-se ser competente dentro do chiqueiro, pois, nem sempre, a história é o preço do suíno. Ressaltam que é preciso baixar os custos, por unidade ou lote, em períodos de baixa. Isto somente é possível com o uso de instrumentos de controle.

Segundo as entrevistas com os associados, até o momento, percebe-se que são as informações, as anotações, o planejamento, o controle, que fornecem segurança para a tomada de decisão estratégica da associação. Sem este processo, não se consegue nada, com clareza, e segurança. 0 exemplo está nas pequenas propriedades, onde não existe o controle e 0 planejamento e onde os problemas tendem a ser maiores. "Pode-se fazer uma pesquisa no meio dos produtores de suínos e verificar se os mesmos estão ganhando dinheiro. A grande maioria vai responder que não e ao observar que números os mesmos possuem, ai se percebe que a grande maioria não faz um controle mais rígido, um planejamento da produção. O que todos sabem é que o preço não está bom para os seus custos. Mas, por outro lado, nunca verificaram onde está o seu problema, onde precisam melhorar, se têm condições de equipar melhor sua estrutura de produção, ou seja, ninguém faz como deveria ser, muito menos atender aos apelos e exigências dos técnicos para o melhor aproveitamento dos recursos e para o ganho da produtividade por unidade ${ }^{7}$. 
Segundo os associados, o PCP é fundamental para a execução das atividades. Quando a associação foi constituída, compravam-se os insumos e vendia-se a produção, sem fazer um controle e um planejamento, mais detalhado, para averiguar os custos de produção e seus lucros. Hoje, é preciso controlar até o que se produz para o consumo pois, se não houver um controle, 0 produtor não tem conhecimento da viabilidade de produzir ou comprar o que consome. $O$ planejamento e o controle são tão importantes que se constituem na base da tomada da decisão.

$O$ que se percebe é que a associação e os associados somente passaram a dar importância para o planejamento e o controle da produção, como base para o processo de tomada de decisão, a partir de uma conscientização e da necessidade de fazer O PCP. Esta necessidade fez com que a associação passasse a procurar e criar mecanismos e formas próprias de registrar e de anotar os fatos ocorridos.

A conclusão a que se chega é que o produtor deve sentir a necessidade de controlar, de fazer um planejamento, pois, sem essa premissa, isso não funciona. É exatamente isso que a associação sente: a necessidade de planejar e de controlar para obter os melhores resultados, para verificar onde estão os problemas. Foi isso que a associação fez, no setor de suínos e leiteiro, e tem a clara certeza de que, nos demais setores, é preciso, o mais breve possível, ter o mesmo controle e planejamento.

A presença de um Técnico é fundamental para o processo de tomada de decisão, pois funciona como um Assessor, ou seja, o Técnico deve trabalhar como um orientador porque conhece outras propriedades e situações que apresentam características semelhantes $e$, portanto, tem todas as condições de "saber como funciona melhor". A presença do Técnico é fundamental para a viabilização da associação, como um todo, e não apenas de um determinado setor, pois este consegue visualizar melhor a associação, como um todo, dando 
assim orientações sobre a integração das diferentes atividades, com o objetivo de proporcionar um melhor rendimento técnico, financeiro e econômico da associação.

Segundo os associados, o objetivo principal da associação é continuar trabalhando em união, em conjunto e, dessa forma, melhorar cada vez mais na questão da produção. Todos os filhos do associados estudam o que pode indicar que de fato a associação está alcançando os objetivos iniciais.

Os sócios afirmam que, para melhorar a situação atual, seriam necessários mais investimentos, com juros subsidiados e uma política agrícola bem definida para pequeno agricultor. Como conclusão, afirmam que, é preciso, se especializar Um dos membros frisa num linguajar bem simples: "temos que ser bom em tudo se nosso objetivo é vender para fora". O que levou-os a esta conclusão, foi a própria vivência do dia a dia, onde sentiram a necessidade de melhoramentos constantes em todos os setores e, dessa forma, especializarse nas atividades desenvolvidas. Esta especialização, tendo por objetivos um aumento da eficiência e da eficácia operacional, segundo a associação, somente será possível com a utilização, mais intensa, de instrumentos que forneçam informações precisas sobre o desenvolvimento das atividades da associação, ou seja, "planejando e controlando tudo a respeito do setor para poder maximizar os lucros e minimizar os custos".

Segundo os associados, uma última questão que deve necessariamente ser levada em consideração é que o processo de tomada de decisão da entidade, baseado num sistema de planejamento e controle da produção, adotado e executado pelos próprios envolvidos, viabiliza o processo de produção dos vários setores. A própria eficiência e eficácia da associação depende, fundamentalmente, da eficiência e da eficácia deste sistema, na medida em que, viabiliza um aumento da produtividade e da racionalidade, no uso dos fatores de produção, necessários para a execução das atividades. 


\section{UM MODELO DE PCP PARA ASSOCIAÇÕES DE PRODUÇÃO COLETIVA}

Esta parte do trabalho tem por objetivo apresentar, a partir das informações obtidas junto à Associação dos Agricultores de Nova Ronda Alta, um modelo de Planejamento e Controle da Produção que possa ser utilizado para um melhor gerenciamento das atividades. Para tanto, utilizou-se, como ponto de partida, os próprios instrumentos de PCP existentes, atualmente, na associação. Por outro lado, pretende-se, também, que este modelo de PCP também seja útil às demais Associações de pequenos agricultores que apresentam características operacionais semelhantes às da AANRA.

Podemos, sem dúvida, afirmar que as associações de pequenos agricultores podem ser consideradas como sistemas abertos e que mantêm intensas relações com outros ambientes $e$, assim, o planejamento e o controle da produção são de difícil execução, mas de vital importância, para a unidade de produção.

De acordo com BIALOSKORSKI NETO (1994, p. 15), "em dependência de um bom planejamento e o posterior controle das atividades produtivas, a unidade de negócios na agricultura tem condições de cumprir com seus objetivos, de melhor se relacionar com o ambiente externo e, como conseqüência, de aumentar os níveis de eficiência e eficácia. $E$, de acordo com o seu crescimento econômico, também ter condições de apurar as funções de direção e de organização, em dependência direta com o tamanho da empresa". Assim, em um mercado que se apresenta cada vez mais competitivo, verifica-se a necessidade de um sistema de planejamento e de controle da produção, mesmo que simplificado, de forma a oferecer condições de direção e organização às Associações de produção coletiva. 


\subsection{O planejamento da produção}

Como o planejamento da produção se trata de um processo no qual, normalmente, enfrentam-se situações e problemas em que, para resolvêlos, temos que tomar caminhos que ainda não conhecemos, não será possível prever toda a ação, em um só momento. Isto, em outros termos, significa que teremos que construir, passo a passo, o caminho para resolver os problemas e as dificuldades encontradas, bem como determinar as ações necessárias para a sua superação.

A primeira questão que necessita ser colocada, portanto, é a identificação dos problemas e as suas causas, bem como a definição dos objetivos e serem alcançados. Para tanto, faz-se necessária uma coleta e sistematização do maior número de informações e dados a respeito da atual situação. Por outro lado, faz-se também necessária a discussão, a partir das contribuições e das experiências individuais dos associados.

Estes procedimentos permitirão uma correta visualização dos problemas e da situação atual e de suas possiveis causas. Muito provavelmente, este seja um dos procedimentos mais importantes para o sucesso de qualquer tipo de planejamento, na medida em que se constitui na base sobre a qual serão desenvolvidas e discutidas todas as possiveis alternativas. Ao dar este primeiro passo, a Associação pode se defrontar com uma das seguintes situações: o grupo tem informações suficientes ou o grupo não possui informações e dados que permitam uma correta determinação dos problemas e suas causas. No segundo caso, para se sentir mais seguro, o grupo deverá procurar o apoio de outras pessoas, que dispõem de mais informações sobre os problemas da situação em estudo.

A partir da clara definição dos problemas e das suas causas, deve-se definir aqueles que são os mais importantes. Dentre estes, eleger os que 
têm possibilidades de enfrentamento e solução. Se forem várias as causas que podem ser enfrentadas, tem-se que escolher aquelas que devem ser atacadas primeiro e as que podem ficar para etapas posteriores.

Estas decisões deverão, necessariamente, conduzir às primeiras definições em relação ao objetivo geral e aos objetivos intermediários, bem como à ordem de prioridades, ou seja, projetar alternativas que conduzam à resolução dos problemas. O que, porém, fica claro, é que quanto mais clareza se tiver sobre as causas da situação enfrentada e sobre onde se pretende chegar, melhor será a eficiência e a eficácia das decisões a respeito dos problemas.

A segunda questão diz respeito ao estudo e estabelecimento das possíveis estratégias de ação, isto é, à busca de caminhos e meios que permitam alcançar os objetivos desejados. A partir de uma clara definição dos problemas e dos objetivos, deve-se escolher as ações necessárias para concretizá-los. Segundo BIALOSKORSKI NETO (1994, p.18) "o importante é que esses passos devem ser simplificados e responder a questionamentos tais como: o que fazer? quanto fazer? quando fazer? quem deve fazer? como fazer?"

A terceira questão relaciona-se ao estudo da ação concreta, ou seja, o detalhamento operacional das atividades previstas. Uma vez definida a estratégia de ação, a próxima etapa leva ao detalhamento e à delimitação das atividades e das tarefas. Nesta etapa, ocorre a quantificação das ações necessárias para alcançar os objetivos. Esta quantificação ocorre, por sua vez, em dois momentos distintos. Num primeiro momento, se faz necessária a quantificação física das necessidades para operacionalizar as atividades. Esta quantificação física se relaciona à necessidade de insumos, bem como à tecnologia a ser utilizada. Estas definições serão importantes para a definir o plano físico de produção, o qual deverá conter um histórico operacional das diferentes tarefas e atividades a serem desenvolvidas. Num segundo momento, deverá ser feita a quantificação financeira das atividades e das tarefas, ou seja, a 
partir do plano físico de produção, deverão ser determinados os recursos financeiros necessários, bem como as possiveis receitas para a operacionalização das atividades, na Associação.

Em termos operacionais, as duas primeiras questões apresentadas deverão ser encaminhadas a partir de uma intensa indagação e discussão, em grupo, na Associação. Neste processo de indagação e discussão com os associados sobre os problemas e as suas causas e da definição dos objetivos e das prioridades de enfrentamento, bem como da determinação da estratégia de ação, é de fundamental importância que se faça o registro apropriado. Este registro poderá ser efetuado num livro de atas ou, então, num caderno que poderá ser utilizado, permanentemente, para tal fim. Poderá, ainda, ser utilizada uma tabela especifica, conforme exemplo abaixo, que contenha os seguintes itens.

a) Um espaço para a sua identificação. Este espaço deverá conter informações que permitam identificar a respectiva Associação, bem como, a atividade e 0 período ao qual este se refere;

b) Um espaço para a identificação dos principais problemas. Neste espaço deverão ser relacionados os problemas que estão sendo enfrentados, seja na Associação, seja em atividades específicas da mesma. Como esta é uma das partes mais importante do planejamento, a descrição dos problemas deve ser clara e minuciosa para que represente corretamente os problemas;

c) Um espaço para a descrição das causas dos problemas. Neste espaço deverão ser relacionadas as possíveis causas dos problemas levantados, a partir das informações e das discussões, na Associação. A descrição das causas dos problemas também deverá ser efetuada, de forma clara e minuciosa;

d) Um espaço para a anotação dos objetivos. Os objetivos devem ser definidos, a partir de uma definição a respeito dos problemas e das suas respectivas causas. Assim, os objetivos aqui relacionados devem ser no sentido do enfrentamento e 
solução a estes problemas. Estes objetivos também devem estar, intimamente relacionados, aos objetivos gerais da Associação;

e) Um espaço para a descrição das possíveis estratégias de ação. A descrição das estratégias de ação diz respeito aos diferentes caminhos e meios que permitam alcançar os objetivos desejados.

Estes passos são descritos na tabela 15.

Tabela 15 - Planejamento da produção

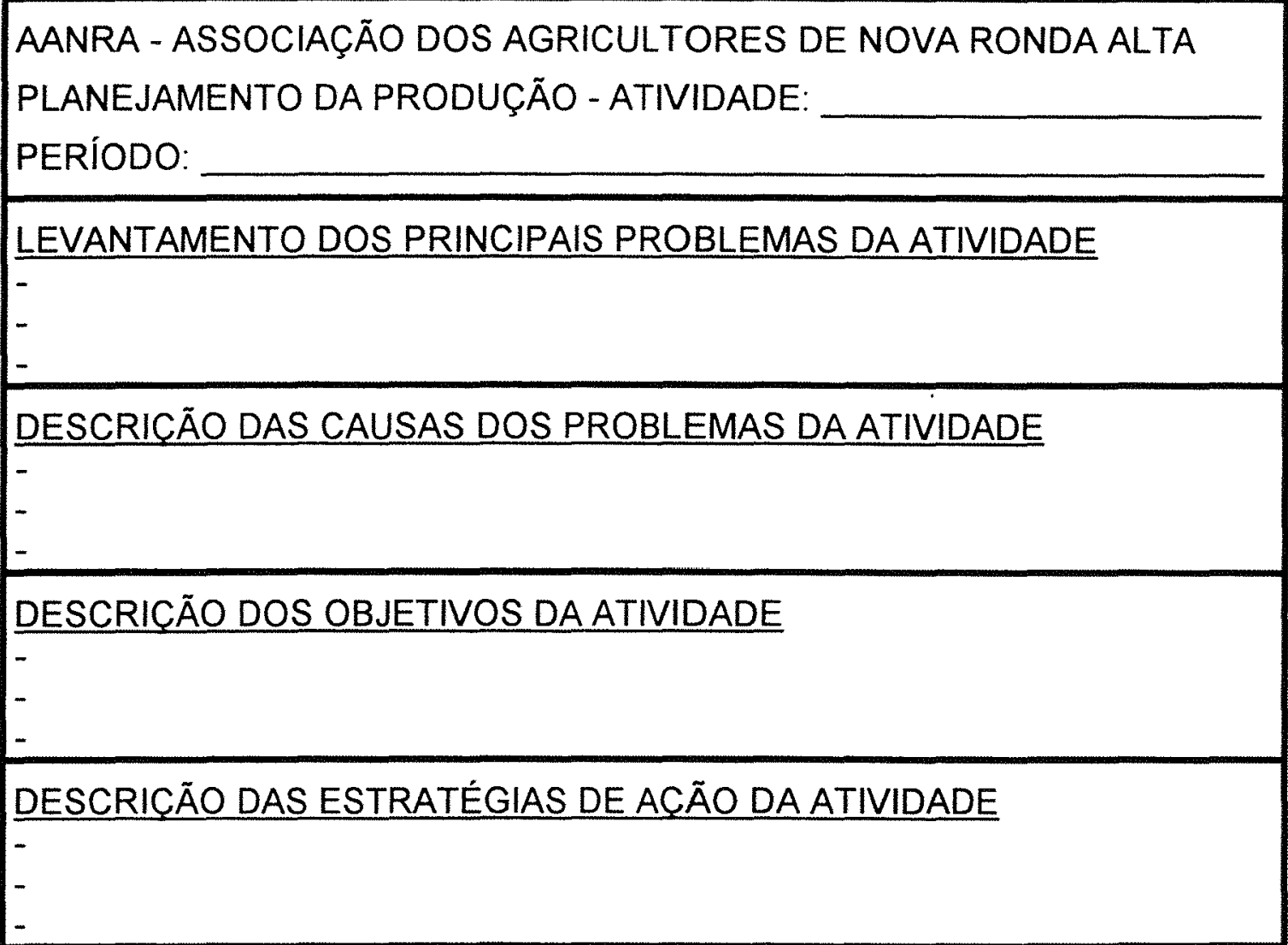

Fonte: Tabela elaborada pelo Autor

A partir destas definições iniciais a respeito do processo de planejamento, seja da Associação como um todo, seja de atividades específicas da Associação, inicia-se a segunda etapa do planejamento, que está relacionado ao plano físico de produção, ou seja, à quantificação física das necessidades para operacionalizar as atividades. Cabe relembrar que esta quantificação física 
relaciona-se à necessidade de insumos, bem como. à tecnologia a ser utilizada. Além disto, o plano físico de produção deverá conter um histórico operacional das diferentes tarefas e das diferentes atividades que deverão ser desenvolvidas. Num primeiro momento, e com o uso dos tabelas (16 e 17) apresentadas a seguir, registram-se os dados técnicos de produção, que são importantes, principalmente, como forma de planejamento do nível tecnológico da produção. Para cada atividade desenvolvida deverá ser utilizada uma tabela $e$, dependendo do tipo de atividades, deverão ser utilizadas ambos as tabelas.

Tabela 16 - Planejamento do processo técnico de produção para sistemas de cultivo.

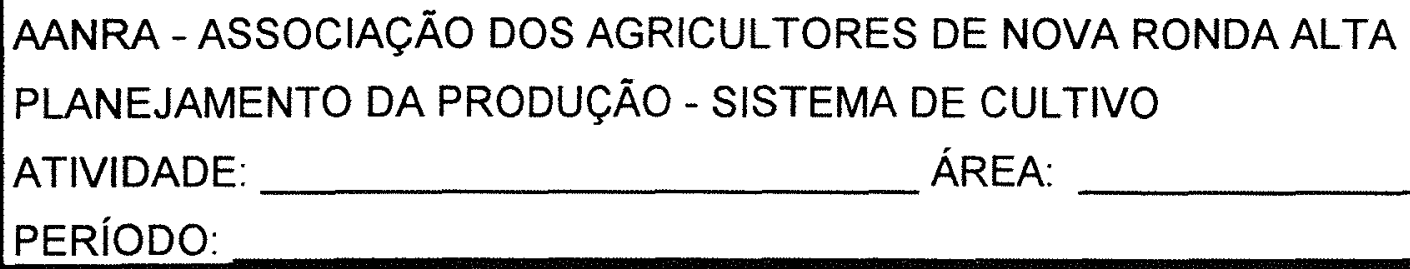

DESCREVER COMO SERÁ O PLANTIO

.

DESCREVER COMO SERÃO OS TRATOS CULTURAIS

-

Fonte: Tabela elaborada pelo Autor 
Tabela 17 - Planejamento do processo técnico de produção para sistemas de criação.

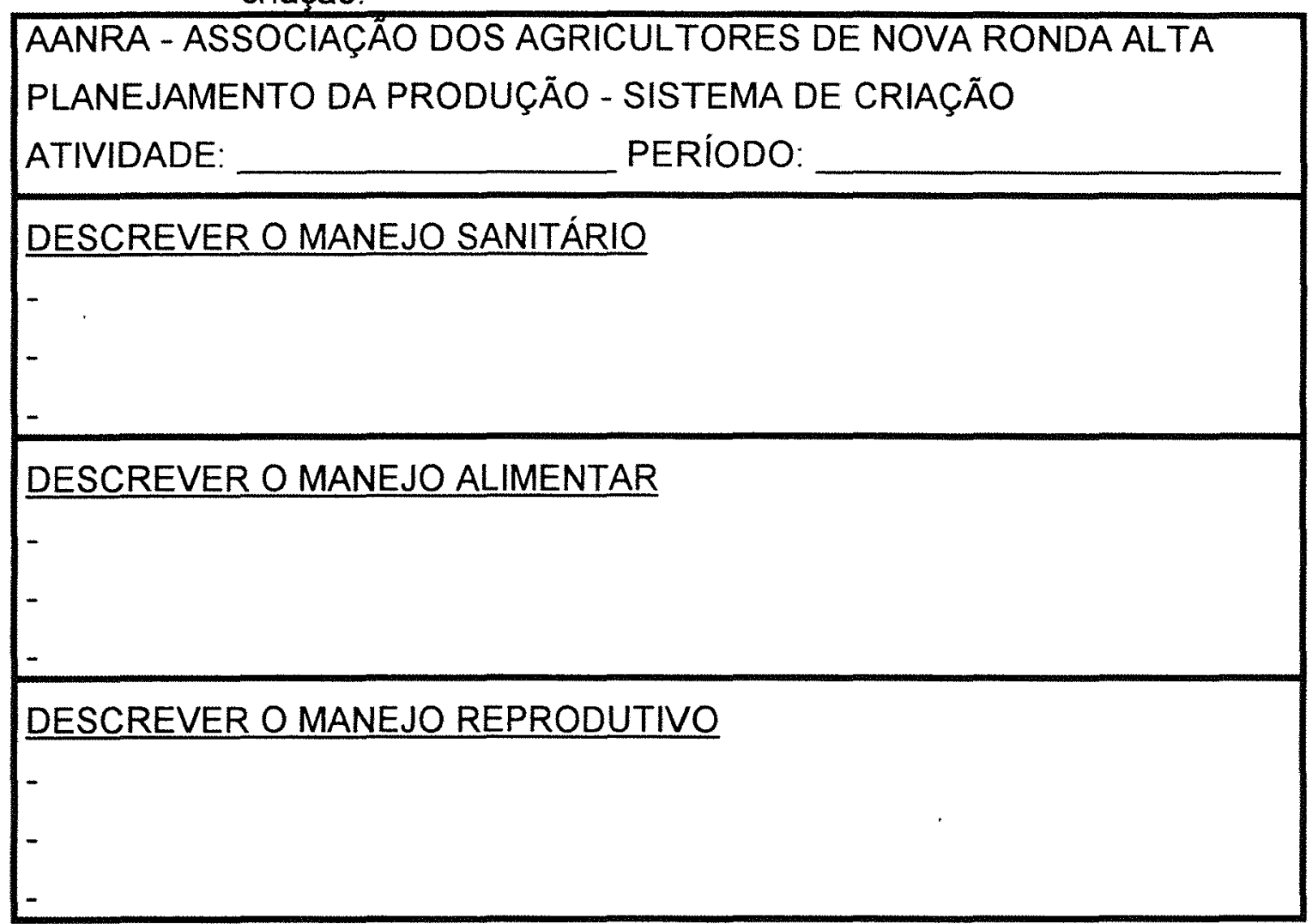

Fonte: Tabela elaborada pelo Autor

A tabela número 16 , serve para o registro das informações planejadas para as atividades de cultivo, sejam estas lavouras temporárias ou permanentes, enquanto que a tabela número 17 , é recomendada para as criações, ou seja, para a atividade de pecuária, leiteira e de corte, e de suínos, entre outras.

Estes procedimentos permitirão projetar, para as atividades que serão desenvolvidas na Associação, o seu processo de produção, ou seja, permitirão planejar a produção, em termos da sua tecnologia, bem como as necessidades físicas e financeiras.

O passo seguinte é a quantificação física e financeira de todos os insumos necessários ao processo de produção das atividades. Para 
isto, poderão ser utilizadas as tabelas 18 e 19. Esta quantificação também deverá ser feita para cada uma das atividades desenvolvidas, devendo seguir os seguintes critérios:

Tabela 18 - Planejamento físico e financeiro da produção para sistemas de cultivo.

\begin{tabular}{|c|c|c|c|}
\hline \multicolumn{4}{|c|}{$\begin{array}{l}\text { AANRA - ASSOCIAÇÃO DOS AGRICULTORES DE NOVA RQ } \\
\text { PLANEJAMENTO DA PRODUÇÃO - SISTEMA DE CULTIVO } \\
\text { ATIVIDADE: _ ÁREA: } \\
\text { PERÍODO: }\end{array}$} \\
\hline Especificacão & Quantidades & Valor Unitário & Valor Total \\
\hline 1. RECEITAS TOTAIS & & & \\
\hline - Com as Vendas & & & \\
\hline - Com o consumo próprio & & & \\
\hline- & & & \\
\hline- & & & \\
\hline 2. Despesas com o preparo do solo & & & \\
\hline- & & & \\
\hline- & & & \\
\hline 3. Despesas com o plantio & & & \\
\hline- & & & \\
\hline- & & & \\
\hline 4. Despesas com os tratos culturais & & & \\
\hline- & & & \\
\hline - & & & \\
\hline 5. Despesas com a colheita e vendas & & & \\
\hline- & & & \\
\hline- & & & \\
\hline 6. DESPESAS TOTAIS $(2+3+4+5)$ & & & \\
\hline 7. Margem de Contribuição $(1-6)$ & & & \\
\hline
\end{tabular}

Fonte: Tabela elaborada pelo Autor 
Tabela 19 - Planejamento físico e financeiro da produção para sistemas de criação.

\begin{tabular}{|c|c|c|c|}
\hline \multicolumn{4}{|c|}{$\begin{array}{l}\text { AANRA - ASSOCIAÇÃO DOS AGRICULTORES DE NOVA RONDA ALTA } \\
\text { PLANEJAMENTO DA PRODUÇÃO - SISTEMA DE CRIAÇÃO } \\
\text { ATIVIDADE_ PERIOODO }\end{array}$} \\
\hline ESPECIFICAÇÁO & Quantidade & Valor Unitário & Valor total \\
\hline \multicolumn{4}{|l|}{ 1. RECEITAS TOTAIS } \\
\hline \multicolumn{4}{|l|}{ - Com as vendas } \\
\hline \multicolumn{4}{|l|}{ - Com o consumo próprio } \\
\hline \multicolumn{4}{|l|}{ 2. Despesas com o manejo sanitário } \\
\hline \multicolumn{4}{|l|}{-} \\
\hline \multicolumn{4}{|l|}{-} \\
\hline \multicolumn{4}{|l|}{-} \\
\hline \multicolumn{4}{|l|}{ 3. Despesas com o manejo alimentar } \\
\hline \multicolumn{4}{|l|}{-} \\
\hline \multicolumn{4}{|l|}{-} \\
\hline \multicolumn{4}{|l|}{-} \\
\hline \multicolumn{4}{|c|}{ 4. Despesas com o manejo reprodutivo } \\
\hline \multicolumn{4}{|l|}{-} \\
\hline \multicolumn{4}{|l|}{-} \\
\hline \multicolumn{4}{|l|}{-} \\
\hline \multicolumn{4}{|c|}{ 5. Despesas com a venda da produção } \\
\hline \multicolumn{4}{|c|}{-} \\
\hline \multicolumn{4}{|c|}{-} \\
\hline \multicolumn{4}{|l|}{ - } \\
\hline \multicolumn{4}{|l|}{ 6. DESPESAS TOTAIS $(2+3+4+5)$} \\
\hline 7. Margem de Contribuição $(1-6)$ & & & \\
\hline
\end{tabular}

Fonte: Tabela elaborada pelo Autor

a) Especificação e caracterização dos insumos que serão utilizados no processo de produção. Esta especificação e esta caracterização deverão permitir, aos 
usuários do planejamento da produção, uma perfeita identificação dos diferentes insumos que serão utilizados nas atividades.

b) Especificação das respectivas quantidades dos insumos que serão utilizadas nas atividades. Este item é importante porque projetará a quantidade necessária dos diferentes insumos.

c) Especificação do valor unitário dos insumos. Neste espaço, deverá ser feita uma projeção dos referidos custos unitários dos insumos necessários ao processo de produção.

d) Especificação do valor total dos insumos. A partir das quantidades necessárias e dos custos unitários dos diferentes insumos podemos determinar o custo total. Isto possibilitará a projeção dos custos totais das diferentes atividades.

A margem de contribuição, neste caso, constitui-se no montante de recursos disponiveis para o pagamento da manutenção da estrutura fixa de produção, bem como, para a produção de lucros para a Associação.

Outro instrumento de planejamento da produção é a projeção do fluxo de caixa da Associação. Para SDANOWICZ (1986), denomina-se como fluxo de caixa de uma empresa, o conjunto de ingressos e de desembolsos de numerário, ao longo de um período determinado. Assim, o fluxo de caixa consiste na representação dinâmica da situação financeira de uma empresa, considerando-se todas as fontes de recursos e todas as aplicações, em itens do ativo.

O principal objetivo do fluxo de caixa é dar uma visão das atividades programadas, bem como das operações financeiras que são desenvolvidas, no período estudado. Com o passar do tempo, as informações do fluxo de caixa podem ser muito úteis para aumentar a eficiência e a eficácia do processo de planejamento da produção, na Associação. Assim sendo, o fluxo de 
caixa deve permitir determinar a quantidade de recursos próprios de que a Associação dispõe, em dado período, e decidir pela sua aplicação da forma mais rentável possível, bem como analisar os recursos de terceiros que satisfaçam as necessidades da entidade. Por outro lado, o fluxo de caixa deve permitir, também, programar os ingressos e os desembolsos de caixa, de forma criteriosa, permitindo determinar o período em que deverá ocorrer uma possível carência de recursos e o seu montante, de modo que haja tempo suficiente para as medidas necessárias.

O fluxo de caixa da Associação deve ser constituído a partir das atividades que deverão ser desenvolvidas durante o período em estudo, ou seja, o fluxo de caixa será projetado a partir das informações a respeito das receitas e das despesas de todas as atividades previstas.

A grande vantagem do fluxo de caixa é que ele permite, aos administradores, uma visão clara da época em que devem ocorrer as entradas e as saídas em dinheiro na Associação. Com o passar do tempo, ele permite que se façam determinadas projeções dos ingressos e dos desembolsos decorrentes do processo operacional das atividades para um determinado período desejado.

O fluxo de caixa pode ser expresso, de forma genérica, pela equação (1):

$S F C=S I C=I-D+E C+A M-A E+R A$.

Nesta equação (1), SFC representa o Saldo Final de Caixa; SIC representa o Saldo Inicial de Caixa; I representa os Ingressos; D representa os Desembolsos; EC representa os Empréstimos a Captar no mercado financeiro para suprir os eventuais déficits; AM representa as Aplicações no Mercado financeiro dos recursos excedentes; $\mathrm{AE}$ representa as Amortizações dos Empréstimos captados no mercado e RA representa os Resgates das Aplicações, no mercado financeiro. 
Para o cálculo do fluxo de caixa, podemos utilizar o tabela $n^{\circ}$ 20. O levantamento e registro dos dados projetados, através do fluxo de caixa, deverá observar os seguintes critérios.

a) O saldo inicial de caixa (SIC), de um período, é sempre igual ao saldo final de caixa (SFC), de período anterior;

b) Os ingressos (I) correspondem aos valores relativos às receitas da Associação, sejam eles provenientes da venda da produção, ou da prestação de serviços ou, ainda, a qualquer receita proveniente das operações da Associação.;

c) Constituem-se em desembolsos (D) todas as operações financeiras decorrentes de pagamentos, gerados pelo processo de produção das atividades desenvolvidas.

d) A disponibilidade em dinheiro (DD) corresponde à quantidade de dinheiro existente, levando-se em consideração somente o saldo inicial de caixa, os ingressos e os desembolsos previstos;

e) O nível desejado de dinheiro (NDD) corresponde à determinação do capital de giro, líquido, necessário para a Associação, em função do volume de ingressos e de desembolsos. Em outros termos, significa o mínimo de dinheiro necessário para que as atividades programadas possam ser desenvolvidas normalmente.

$\mathrm{Na}$ prática, o nível desejado de caixa é a quantidade de dinheiro que a Associação julgar necessária ter no final do período a que se refere o fluxo de caixa. Constitui-se num valor arbitrado, em função dos conhecimentos acumulados sobre o fluxo financeiro da Associação;

f) Uma comparação do nível desejado de dinheiro (NDD) com a disponibilidade de dinheiro (DD), pode mostrar um saldo positivo, indicando um excesso de liquidez. Neste caso, tal excesso poderá ser aplicado no mercado financeiro (AM), para que proporcione rendimentos adicionais. Se o saldo for negativo, deve-se buscar empréstimos (EC) para que as atividades se desenvolvam, normalmente, ou, então, cortar despesas ou atividades deficitárias; 


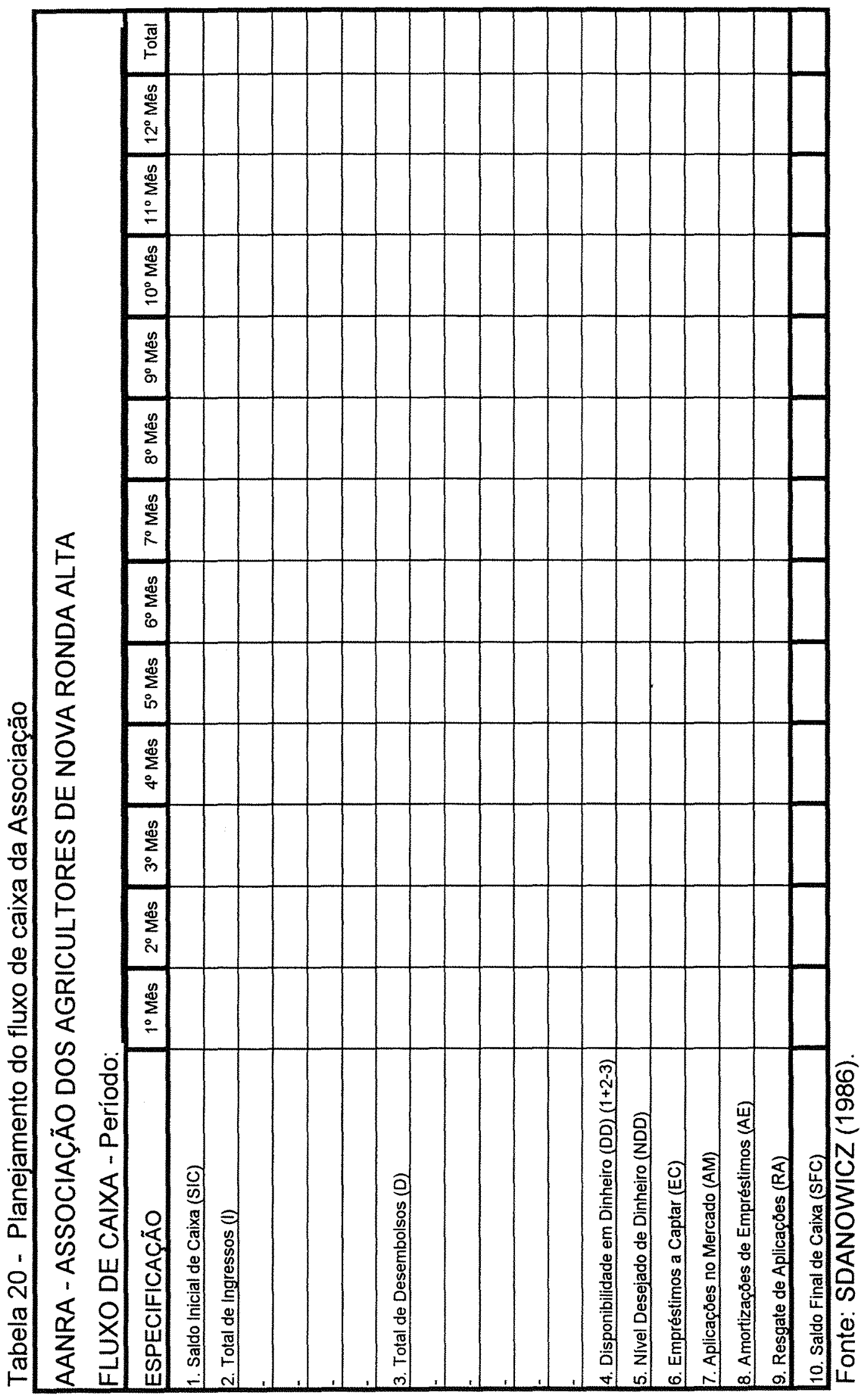


g) As amortizações de empréstimos (AE) se constituem na devolução do principal, tomado emprestado, enquanto que os resgates de aplicações (RA) constituem-se no seu recebimento. As receitas e as despesas financeiras decorrentes da aplicação ou do empréstimo devem estar incluídas nos ingressos e nos desembolsos previstos para os períodos. Antes de tomar a decisão a respeito de empréstimos e aplicações de recursos, deve-se levar em consideração os possiveis resgates e amortizações;

h) O saldo final de caixa (SFC) deve ser igual ao nível desejado de dinheiro (NDD), uma vez que ele representa, assim calculado, o valor que se deseja ter, no final do período.

O fluxo de caixa se constitui, portanto, num importante instrumento de projeção de uma situação futura. Não faz muito sentido o simples levantamento, no final do período, do saldo final. Este só demonstra o volume total de recursos financeiros disponiveis para o período seguinte. Este processo de projeção do fluxo de caixa permite prever, com antecedência, possíveis dificuldades financeiras ou, então, sobras de recursos, em determinados períodos, que poderão se constituir em aplicações alternativas.

\subsection{O controle da produção}

A função administrativa de controle, segundo CHIAVENATO (1990, p.83) "consiste em medir e corrigir o desempenho, para assegurar que os objetivos da empresa sejam atingidos". Assim, o controle deve servir para guiar e regular as atividades da Associação, a fim de garantir o alcance dos objetivos almejados. A partir destas definições, o controle da produção, enquanto última fase do PCP, acompanha, avalia, regula as atividades produtivas da Associação, para mantê-las dentro do que foi planejado e assegurar o alcance dos objetivos. 
Os instrumentos propostos de controle visam, basicamente, suprir uma carência verificada na Associação no que se refere à falta de informações sistematizadas e confiáveis que permitam avaliar o desempenho, bem como tomar decisões futuras.

O primeiro instrumento de controle colocado à disposição da Associação é o controle das entradas e das saídas de dinheiro. Na Associação, o controle de entradas e saídas, é de vital importância para o seu correto funcionamento. São os recursos recebidos, através das vendas dos produtos e com os quais efetuam-se os pagamentos aos fornecedores.

Imagine-se que uma Associação de agricultores resolva controlar melhor suas entradas e saídas em dinheiro, pois os associados estão, constantemente, perguntando onde ele foi aplicado, qual o saldo em caixa, enfim, querem saber $\circ$ que foi feito com o dinheiro da Associação. Como geralmente existem poucos instrumentos de controle, a direção tende a encontrar muitas dificuldades para responder, a estas e outras questões. Este fato tem gerado algumas desconfianças, por parte de alguns associados.

A primeira atitude a ser tomada pela direção da Associação, para tentar resolver o problema, geralmente é eleger um tesoureiro para a entidade. Este, por sua vez, será o responsável pelos recebimentos, pelos pagamentos e pela guarda de todos os documentos da Associação. Porém, passado algum tempo, o problema tende a persistir, na medida em que, cada vez que um associado solicitar alguma informação, o tesoureiro irá perder muito tempo procurando os documentos para saber onde foram gastos os recursos, ou então, para saber o valor de uma determinada entrada.

O passo seguinte, então, é anotar todas as entradas e saídas de dinheiro em um caderno, especificamente destinado para tal fim. Este caderno é denominado livro caixa. O preenchimento do livro caixa normalmente é efetuado ao final de cada dia, quando o tesoureiro, de posse de todos os 
documentos referentes às operações efetuadas, durante o dia, faz as respectivas anotações. Para estes registros, pode ser utilizada a tabela número 21.

$\mathrm{Na}$ parte superior de cada folha do livro caixa existe o número seqüencial da folha, os dados de identificação da Associação e o período ao qual a folha se refere. Este período poderá ser o dia, ou então, o mês. Caso se opte por fazer a divisão por períodos mensais, por existir um movimento reduzido, recomenda-se que os registros, no livro, sejam feitos diariamente, para evitar eventuais esquecimentos ou extravio de documentos e que somente 0 fechamento do livro seja efetuado no final de mês.

Tabela 21 - Controle do livro caixa da Associação

\begin{tabular}{|c|c|c|c|c|}
\hline \multicolumn{5}{|c|}{$\begin{array}{l}\text { AANRA - ASSO } \\
\text { LIVRO CAIXA } \\
\text { PERIODO: }\end{array}$} \\
\hline Data & Histórico & Recebimentos: & Pagamentos & Saldo \\
\hline & Saldo inicial ou valor transportado & & & \\
\hline & - & & & \\
\hline & - & & & \\
\hline & - & & & \\
\hline & - & & & \\
\hline & - & & & \\
\hline & - & & & \\
\hline & - & & & \\
\hline & Saldo final ou valor a transportar & & & \\
\hline
\end{tabular}

Fonte: Tabela elaborada pelo Autor

O saldo inicial ou o valor transportado representa o dinheiro existente, no início do período, devendo ser registrado na coluna correspondente aos recebimentos, por ser um valor positivo. Cabe, aqui, destacar que, nunca existirá um saldo de caixa, inicial ou final, com valor negativo, pois, como este 
instrumento registra entradas e saídas físicas de dinheiro, não poderá sair dinheiro que não tenha entrada na conta. Outra hipótese de utilização deste item é quando os registros de um dia ultrapassam uma folha do livro caixa. Neste caso, é apurado o saldo da folha, somando-se, separadamente, primeiro, os recebimentos mais o saldo inicial e, após, os pagamentos. A seguir, o valor da segunda soma é deduzido da primeira; o valor encontrado é registrado no item saldo final ou valor a transportar $e$, também, no item saldo inicial ou valor transportado, na folha seguinte. Neste caso, e somente neste caso, poderá ocorrer que o valor transportado seja negativo.

As linhas em branco, após o saldo inicial, são destinadas ao registro das operações de recebimentos e pagamentos. Devem ser evitados os lançamentos de forma agrupada, ou seja, deve-se evitar a soma de vários pagamentos e recebimentos e o registro do valor total, exceto quando apresentarem a mesma característica de gasto e receita. Neste espaço (histórico), deve-se descrever, de forma sintética, porém clara, a operação. Deverá, também, constar o tipo e o número do documento que evidencia a operação a quem foi pago ou de quem foi recebido e a que se refere o pagamento ou o recebimento.

O saldo final ou o valor a transportar representa o saldo final de dinheiro disponivel para o início do período seguinte. Para a sua determinação, subtrae-se o total de pagamentos, da soma do valor do saldo inicial com o total de recebimentos.

A partir deste processo de controle do livro caixa, percebe-se uma série de vantagens que facilitam o processo de tomada de decisão, na Associação. Dentre estes destacam-se:

a) $\mathrm{O}$ fato de preencher o controle de caixa provoca uma melhor organização dos documentos da Associação;

b) O controle de caixa permite saber, rapidamente, onde foi gasto o dinheiro da Associação, bem como a origem dos recursos; 
c) O controle de caixa permite conhecer o saldo, atualizado, de caixa e se obter, assim, informações sobre o valor disponível para se gastar.

É importante ressaltar que nem todos os problemas administrativos, relacionados com o processo de produção das atividades da Associação, são solucionados com a introdução do controle de caixa. A utilidade e a confiabilidade desse controle está na qualidade das informações que nele são registradas. Se houver descuidos ou então esquecimentos, tais como deixar de anotar algum documento, os usuários poderão perder a confiança nos controles e não se sentirão seguros em usá-los para tomar as decisões.

Especificamente em relação ao controle da produção das diferentes atividades desenvolvidas na Associação, pode-se utilizar uma série de tabelas semelhantes às utilizadas para o processo de planejamento da produção. Este processo de controle pode ser dividido em duas etapas interligadas e interdependentes, que são o controle do nível tecnológico utilizado (o controle dos processos técnicos de produção, ou seja, a descrição minuciosa das operações desenvolvidas para as diferentes atividades), e o controle físico e financeiro (registro sistemático das quantidades de insumos e seus respectivos valores utilizados nos processos de produção, assim como do volume produzido e o valor correspondente).

O controle do nível tecnológico tem por objetivo produzir um conjunto de informações que apresentem as diferentes técnicas empregadas na produção. Estas informações, em boa parte dos casos, explicam o desempenho econômico das atividades, decorrendo, daí, a necessidade do seu controle. Este controle pode ser realizado com o uso das tabelas 22 e 23. Estas tabelas devem ser usadas para as culturas vegetais (22) ou, então, para as criações (23).

Os dados que devem ser anotados nos diferentes espaços das tabelas necessariamente deverão representar as diferentes operações desenvolvidas nas atividades. Para o registro destas operações, deve-se anotar o seu tipo, a sua data e as condições internas e externas. Por condições internas 
entendemos as diferentes condições que dizem respeito, unicamente, à Associação, tais como, o tipo de máquina, os equipamentos, o número de pessoas envolvidas, o tipo de insumo utilizado, entre outros. As condições externas referem-se aos fatores não controlados pela Associação, tais como, as condições climáticas, a umidade e as condições do solo, entre outras.

Tabela 22 - Controle do processo técnico de produção para sistemas de cultivo. AANRA - ASSOCIAÇÃO DOS AGRICULTORES DE NOVA RONDA ALTA CONTROLE DA PRODUÇÃO - SISTEMA DE CULTIVO ATIVIDADE: ÁREA: PERIODO:

DESCREVER O PREPARO DO SOLO

DESCREVER O PLANTIO

-

DESCREVER OS TRATOS CULTURAIS

-

DESCREVER A COLHEITA E A VENDA DA PRODUCCÃO

Fonte: Tabela elaborada pelo Autor 
Tabela 23 - Controle do processo técnico de produção para sistemas de criação.

AANRA - ASSOCIAÇÃO DOS AGRICULTORES DE NOVA RONDA ALTA
CONTROLE DA PRODUÇÃO - SISTEMA DE CRIAÇÃO
ATIVIDADE:

DESCREVER O MANEJO SANITÁRIO

DESCREVER O MANEJO ALIMENTAR

-

$-$

DESCREVER O MANEJO REPRODUTIVO

$-$

$-$

DESCREVER O DESTINO DA PRODUCÃO

-

-

Fonte: Tabela elaborada pelo Autor

A segunda etapa, o controle físico e financeiro da produção, tem por objetivo anotar, de maneira simples, as despesas e as receitas, bem como as diferentes quantidades de insumos utilizados e de produtos produzidos nas atividades. Estas anotações devem ocorrer, na medida em que estes fatos acontecem, para que sejam armazenadas todas as informações a respeito da evolução das atividades.

Para o controle das quantidades físicas e dos recursos financeiros envolvidos nos processos de produção é importante o registro da data 
de ocorrência, o histórico, de forma sintética, porém clara, as quantidades de insumos utilizados, o seu valor unitário, bem como, o valor total. Para tanto, poderão ser utilizadas as tabelas 24 e 25.

Tabela 24 - Controle físico e financeiro da produção para sistemas de cultivo AANRA - ASSOCIAÇÃO DOS AGRICULTORES DE NOVA RONDA ALTA CONTROLE DA PRODUÇÃO - SISTEMA DE CULTIVO ATIVIDADE: ÁREA: ha.

PERIODO :

\begin{tabular}{|l|l|l|l|l|}
\hline Data & Histórico & Quantidade & Valor Unitário & Valor Total \\
\hline & & & & \\
\hline & & & & \\
\hline & & & & \\
\hline & & & & \\
\hline & & & & \\
\hline
\end{tabular}

Fonte: Tabela elaborada pelo Autor

Tabela 25 - Controle físico e financeiro da produção para sistemas de criação. AANRA - ASSOCIAÇÃO DOS AGRICULTORES DE NOVA RONDA ALTA CONTROLE DA PRODUÇÃO - SISTEMA DE CRIAÇÕES ATIVIDADE: PERÍODO:

\begin{tabular}{|l|l|l|l|l|}
\hline Data & Histórico & Quantidade & Valor Unitário & $\begin{array}{l}\text { Valor } \\
\text { Total }\end{array}$ \\
\hline & & & & \\
\hline & & & & \\
\hline & & & & \\
\hline & & & & \\
\hline & & & & \\
\hline & & & & \\
\hline & & & & \\
\hline
\end{tabular}

Fonte: Tabela elaborada pelo Autor 
Nestas tabelas, os dados devem ser registrados de acordo com a sua ocorrência. As informações anotadas devem estar relacionadas com o montante de despesas e de receitas, provenientes do processo de produção da atividade à qual se referem. Estes procedimentos permitirão à Associação um perfeito controle físico e financeiro de todas as atividades desenvolvidas.

\subsection{Controles auxiliares}

Além destes controles, podem ainda ser adotado um conjunto de controles auxiliares ao processo de tomada de decisão. Estes controles auxiliares têm por objetivo aumentar a eficiência e a eficácia do PCP, na medida em que, produzem um conjunto de informações que são necessárias, quando do planejamento da produção, bem como, para um melhor controle da Associação, como um todo. Estes controles auxiliares são o controle das contas bancárias, o controle dos estoques, o controle das operações com máquinas e o controle da mão-de-obra.

\subsubsection{O controle das contas bancárias}

A simples introdução do livro caixa na associação representa, sem dúvida, um grande avanço em seus controles. Com saldos positivos, no caixa, é interessante, para a associação, manter uma conta bancária que, além de ser mais segura na guarda destes recursos, poderá servir para aplicações financeiras do dinheiro excedente, buscando, com isto, reduzir as perdas que possam ocorrer com o processo inflacionário e, além disto, produzir algum ganho financeiro.

Com o uso de cheques, podem ocorrer problemas no controle desta conta, tornando-se, assim, necessária a adoção de medidas para evitar estes problemas. Neste sentido, é conveniente o tesoureiro manter um controle 
da conta bancária, que pode ser semelhante ao livro caixa. Para tanto, poderá ser utilizada a tabela número 26 , apresentada a seguir.

O registro das operações na conta bancária deve ser de forma simplificada e clara, o suficiente, para que, com uma simples leitura, seja possivel identificar a operação, nesta conta. A cada operação anotada no histórico, seja ela um depósito, seja uma retirada ou então algum pagamento, com o uso de cheques, deve-se tomar o cuidado de calcular o seu saldo, pois, é através deste, que podemos fazer um controle das contas bancárias. Chamamos atenção para que cada conta bancária seja controlada por uma tabela específica.

Tabela 26 - Controle das contas bancárias da Associação

\begin{tabular}{|c|c|c|c|c|}
\hline \multicolumn{5}{|c|}{$\begin{array}{l}\text { AANRA - ASSOCIAÇÃO DOS AGRICULTORES DE NOVA RONDA ALTA } \\
\text { CONTROLE BANCÁRIO - BANCO: CONTA: }\end{array}$} \\
\hline Data & Histórico & Entradas & Saidas & Saldo \\
\hline & & & & \\
\hline & & & & \\
\hline & & & & \\
\hline & & & & \\
\hline & & & & \\
\hline & & & & \\
\hline & & & & \\
\hline & & & & \\
\hline & & & & \\
\hline
\end{tabular}

Fonte: Tabela elaborada pelo Autor

As operações registradas no controle bancário podem, ainda, ser integradas ao controle do caixa, pois, cada vez que se emite um cheque para o pagamento de alguma operação, o respectivo valor pode ser registrado como uma saída de dinheiro do banco, Ao mesmo tempo, haveria uma entrada em dinheiro no caixa, neste mesmo valor. Isto caracteriza uma transferência de dinheiro do banco para o caixa da Associação. A vantagem deste procedimento é que todas as operações que envolvem entradas e saídas de dinheiro estariam 
registradas, num só local, no controle de caixa, facilitando, com isto, o controle geral.

Além disto, deve-se ter o cuidado de que, a cada cheque emitido pela Associação, seja preenchido o seu canhoto, anotando-se o seu valor, a data de emissão, a data em que o cheque será descontado, caso a emissão seja pré-datada, e para quem foi emitido. Após este procedimento, periodicamente, deve-se conferir o controle das contas bancárias, mantido pela Associação, com o extrato emitido pelo banco, e investigar eventuais diferenças, pois é comum os bancos efetuarem débitos automáticos referentes aos custos de talões de cheque, emissão de extratos, juros, entre outros.

\subsubsection{O controle dos estoques}

A Associação, na busca de seus objetivos, trabalha muitas vezes com uma série de produtos, seja na compra de insumos ou na comercialização da produção. Neste tipo de operação, que envolve mercadorias, é de extrema importância que se possua um controle eficiente do volume que se tem em estoque, bem como, a sua movimentação. O objetivo do controle de estoques é a disponibilidade da informação confiável acerca das diferentes quantidades de produtos e de insumos necessários para a operacionalização das atividades.

Nos registros efetuados na ficha de controle de estoque existe, conforme tabela 27 , para cada tipo de operação (entrada ou saída de produtos) um espaço referente ao tipo de operação, à quantidade, ao preço unitário e ao valor total.

A coluna correspondente à quantidade não deve trazer grandes dificuldades. Porém, é no item preço unitário que, geralmente, depara-se com dúvidas, tais como: qual o preço com o qual se registra uma compra ou com 
que preço se dará baixa em um produto, quando da sua venda. A seguir, apresentamos algumas considerações a respeito destes problemas.

a) Sempre que se efetuar a compra de algum produto, a coluna de preço unitário, no grupo das entradas, deverá refletir todos os custos que existem para esta aquisição. Desta forma, deve-se incluir, para o cálculo do preço unitário, o preço da mercadoria, em questão; o frete, mesmo que o seu valor não esteja incluído na nota fiscal; todos os demais custos, como seguros e encargos financeiros que a Associação incorrer para adquirir a mercadoria.

b) Sempre que se efetuar a venda, o valor do custo unitário a ser registrado no item saídas da ficha de controle de estoque, será o último preço unitário registrado na coluna correspondente ao saldo, desta ficha. Assim, no item saída, sempre registrar o valor de custo do produto, independente do preço a que foi vendido.

c) Sempre que se efetuar uma nova compra e o preço for diferente do anterior, o preço no item saldo será modificado levando-se em consideração, para tanto, o seguinte cálculo. O novo preço do item saldo é igual, à soma do valor do saldo, antes da compra, com o valor da nova compra, dividido pela soma do saldo em quantidades, antes da compra, com a quantidade comprada.

Este método de registro na ficha de controle de estoque é chamado de custo médio ponderado, porque, a cada nova compra, o preço dos produtos em estoque é alterado. Existem, porém, outros métodos como: o primeiro que entra é o primeiro que sai (PEPS), e o último que entra é o primeiro que sai (UEPS).

Adicionalmente, é importante destacar que se mantenham atualizadas, as fichas de controle dos estoques, com todas as entradas e saídas registradas e com o seu saldo atualizado. É também recomendável que, periodicamente (no minimo uma vez por ano), se confira a quantidade registrada como saldo, na ficha, com a quantidade realmente existente em estoque, para evitar possíveis problemas operacionais e gerenciais na Associação. 


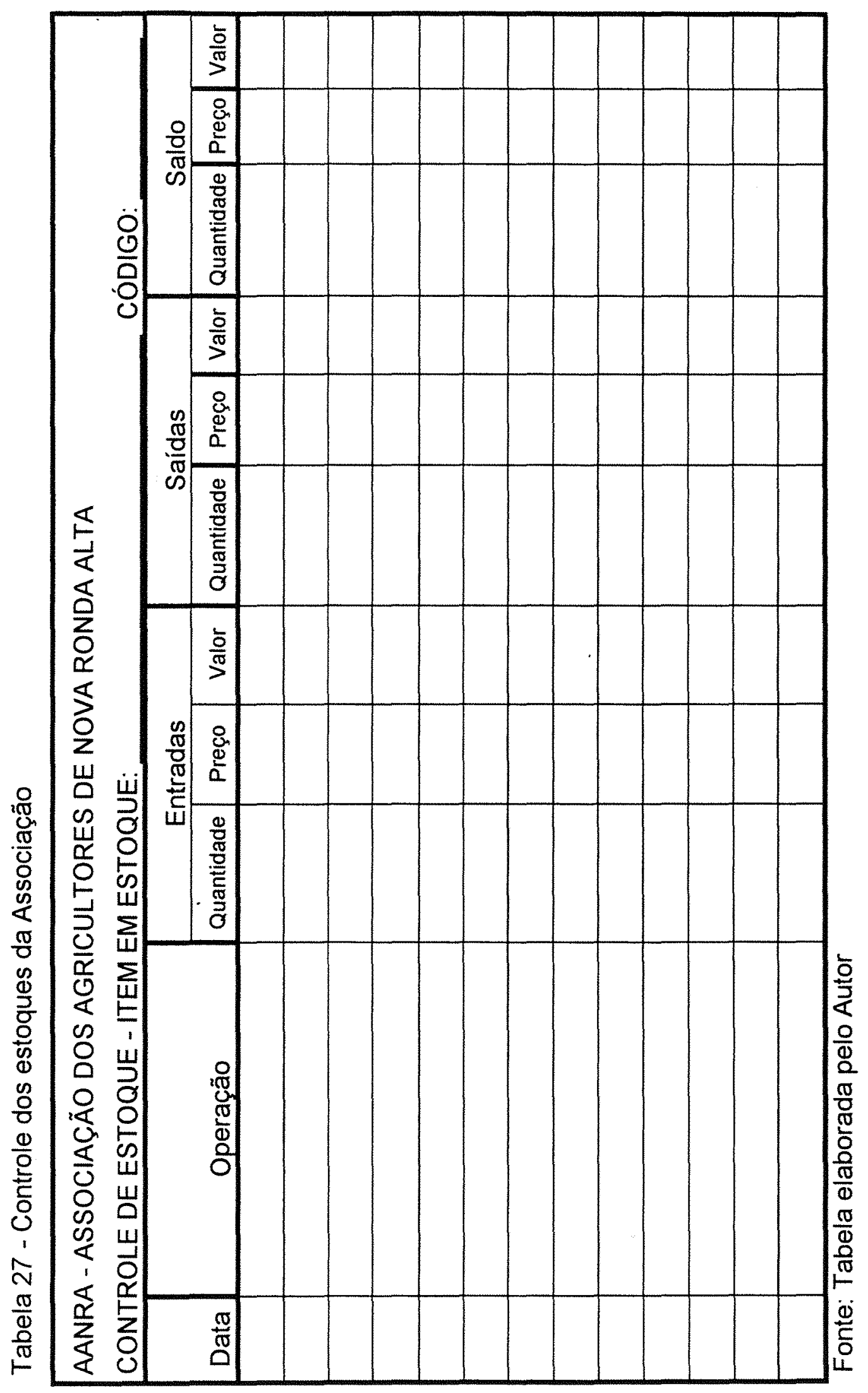




\subsubsection{O controle das operações com máquinas}

O controle das máquinas tem por finalidade tornar o seu uso mais racional e eficiente e consiste no registro, sistemático, da utilização do maquinário, durante o desenvolvimento das atividades. Este controle poderá, com o passar dos períodos produtivos, criar índices técnicos para cada operação realizada na Associação. A partir destes índices, a Associação poderá tornar o uso das máquinas mais eficiente $e$, conseqüentemente, produzir uma redução dos custos de manutenção e de uso das mesmas. Os índices técnicos dizem respeito ao tipo de operação desenvolvida, o tempo necessário, o consumo de combustível, bem como o gasto com a manutenção e a área trabalhada.

O controle das operações, conforme tabela número 28 , deverá ser efetuado por máquina, ou seja, para cada máquina existente na Associação, deverá ter um tabela de controle. O registro dos dados, na tabela, deverá ser feito pelo operador da máquina, após concluída a operação. Recomenda-se que a tabela de controle permaneça, sempre, junto à máquina, pois este procedimento facilitará o registro das dados.

No espaço reservado às operações deverá ser registrado o tipo e a finalidade da operação desenvolvida. O registro do tipo e características do equipamento auxiliar é importante, porque permite comparar a eficiência e a racionalidade da máquina, com o uso de diferentes equipamentos. A duração e a área trabalhada permitirão determinar, para cada tipo de área, um tempo mínimo e máximo necessário. Os dados sobre o consumo de combustível e gastos com manutenção, bem como, com a identificação do operador permitirão, conclusões acerca da eficiência operacional das máquinas e dos operadores. 


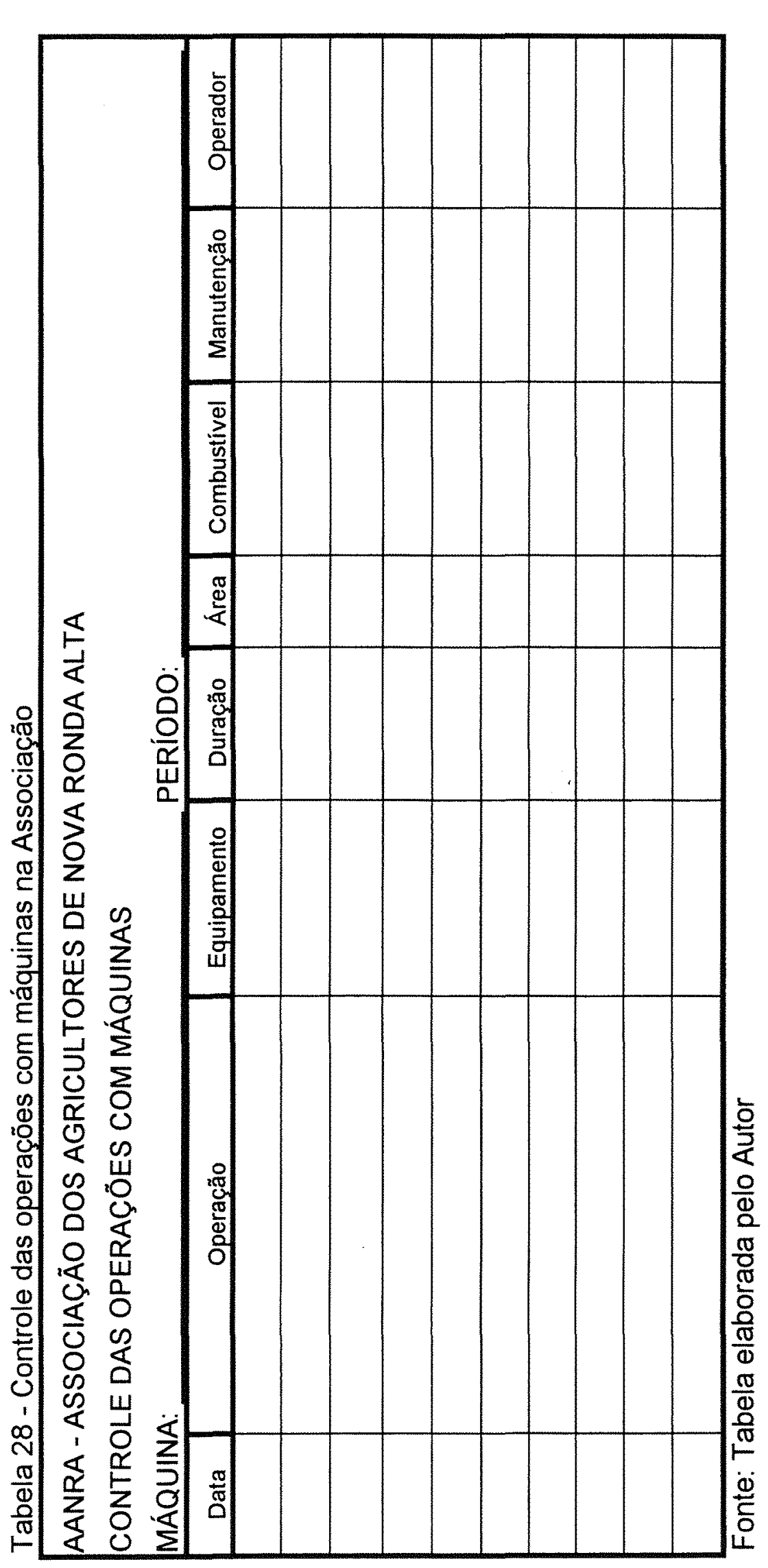




\subsubsection{O controle da mão-de-obra}

O controle da mão-de-obra constitui um dos mais importantes controles auxiliares, na Associação, na medida em que, geralmente, é um referencial utilizado para $\circ$ rateio dos resultados operacionais das atividades desenvolvidas. Assim, o controle da mão-de-obra tem por objetivo controlar as atividades desenvolvidas pelos Associados, bem como controlar o tempo dispendido nestas atividades.

Estes controles podem, portanto, ser de duas formas. A primeira forma é o controle por Associado, que permite controlar as atividades e o tempo gasto, por cada membro da associação. Permite também determinar a produtividade individual do trabalho, por tipo de atividade desenvolvida. A segunda forma é o controle grupal das atividades. O controle grupal permite controlar o tempo total gasto nas atividades, como também determinar a produtividade do setor, em termos de tempo necessário para o desenvolvimento das tarefas. Para estas duas formas de controle, poderão ser utilizadas as tabelas números 29 e 30 .

Tabela 29 - Controle individual da mão-de-obra

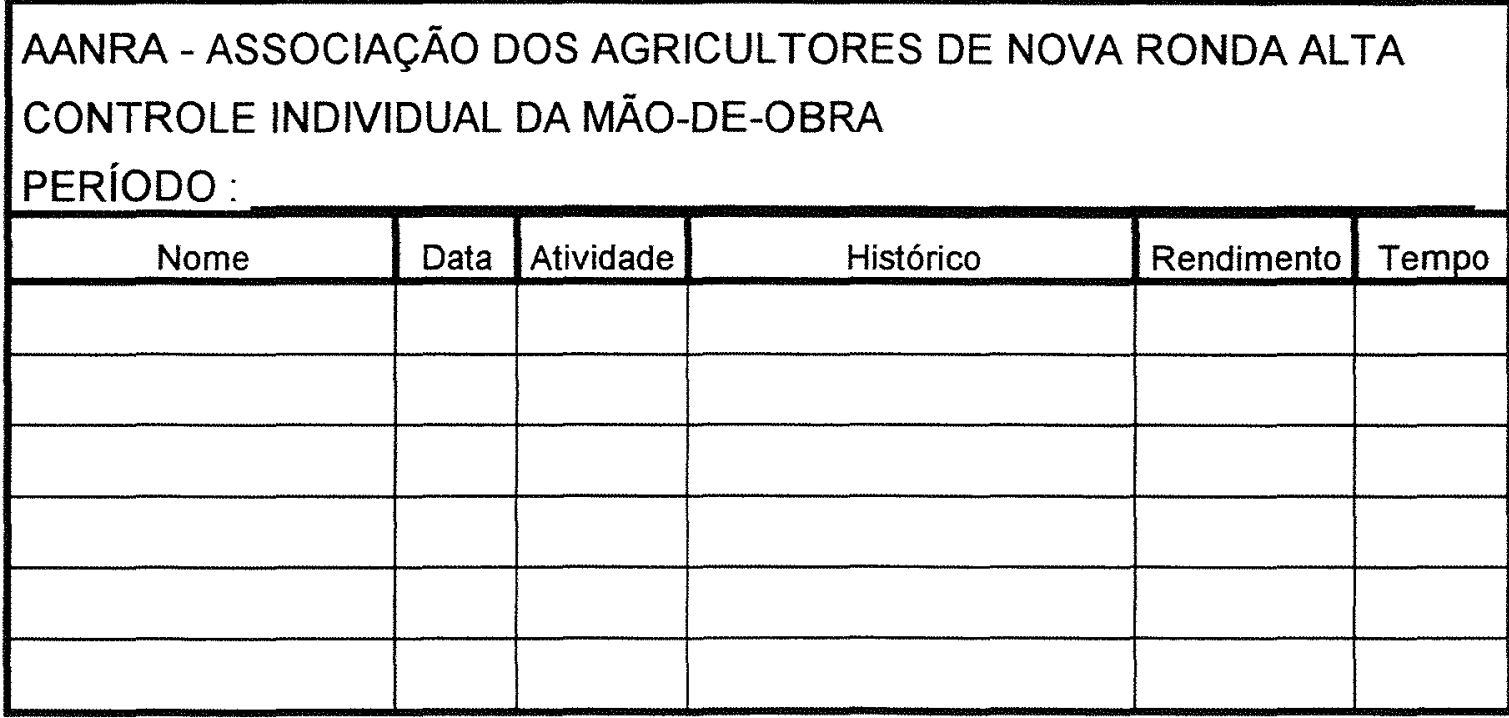

Fonte: Tabela elaborada pelo Autor 
Tabela 30 - Controle grupal da mão-de-obra

\begin{tabular}{|c|c|c|c|c|c|}
\hline \multicolumn{6}{|c|}{$\begin{array}{l}\text { AANRA - ASSOCIAÇÃO DOS AGRICULTO } \\
\text { CONTROLE GRUPAL DA MÃO-DE-OBRA } \\
\text { PERIOODO: }\end{array}$} \\
\hline Data & Atividade & Histórico & $N^{0}$ Pessoas & Rendimento & Tempo \\
\hline & & & & & \\
\hline & & & & & \\
\hline & & & & & \\
\hline & & & & & \\
\hline & & & & & \\
\hline & & & & & \\
\hline & & & & & \\
\hline & & & & & \\
\hline & & & & & \\
\hline & & & & & \\
\hline
\end{tabular}

Fonte: Tabela elaborada pelo Autor

Este controle pode, também, com o passar do tempo, auxiliar na determinição de coeficientee técnicos, relacionados com o tempo necessário para a execução das atividades da Associação. Estes tempos técnicos relacionam-se com a produtividade física do fator de produção trabalho.

6.4. A comparação entre o Planejamento e o Controle da Produção e a apuração do resultado final

Com a evolução do processo de PCP, na Associação, podemos, como parte final deste processo, apurar o resultado das diversas atividades desenvolvidas, bem como do seu conjunto. Esta apuração do resultado assume a função de, ao mesmo tempo, levantar o resultado final e comparar o processo de planejamento com o de controle da produção. Para 
tanto, após o processo de planejamento da produção, devemos tomar as seguintes providências:

1) Quando se iniciar o processo operacional das atividades deve ser aberta uma tabela para o registro do sistema de cultivo ou de criação (processo técnico) e outra tabela para o registro das despesas e das receitas.

2) Durante o ciclo de produção, todos os gastos com a atividade são anotados, bem como são controlados os demais itens referentes aos controles auxiliares.

3) Ao final do ciclo de produção das atividades, todas as despesas são agrupadas, segundo as suas características, isto é, somam-se todas as anotações referentes ao mesmo tipo de gasto (por exemplo, somam-se todas as despesas com combustiveis de determinada atividade), até que todos os valores absorvidos pela atividade estejam em grupos homogêneos.

4) São incluídas, ainda, as receitas das atividades. Caso uma parcela da produção obtida, nas diferentes atividades, ainda esteja em estoque ou seja utilizada como insumo no período seguinte, ou, ainda, for destinada ao consumo próprio, essa parcela também será registrada como receita.

5) Finalmente, todos estes valores serão transferidos para um tabela resumo e é apurado o resultado líquido da atividade. Para isto, podemos utilizar a tabela número 31.

Esta tabela de controle de produção tem a função de organizar as informações referentes a cada uma das atividade desenvolvidas na Associação. Nela devem ser registrados dados econômicos e financeiros, de forma detalhada.

Na tabela de controle da produção, são considerados os custos, efetivos ou não, efetuados por ocasião da compra ou na utilização de 
insumos e de produtos em estoque, com a finalidade de produzir determinado bem.

Tabela 31 - Apuração do resultado das atividades

AANRA - ASSOCIAÇÃO DOS AGRICULTORES DE NOVA RONDA ALTA CONTROLE DA PRODUÇÃO - APURAÇÃO DO RESULTADO LÍQUIDO ATIVIDADE: EXERCÍCIO:

\begin{tabular}{|c|c|c|c|c|c|}
\hline \multicolumn{3}{|c|}{ RECEITAS } & \multicolumn{3}{|c|}{ DESPESAS } \\
\hline Histórico & $\begin{array}{c}\text { Valor } \\
\text { Planejado } \\
\end{array}$ & $\begin{array}{c}\text { Valor } \\
\text { Executado } \\
\end{array}$ & Histórico & $\begin{array}{l}\text { Valor } \\
\text { Planejado } \\
\end{array}$ & $\begin{array}{c}\text { Valor } \\
\text { Executado } \\
\end{array}$ \\
\hline & & & & & \\
\hline & & & & & \\
\hline & & & & & \\
\hline & & & & & \\
\hline & & & & & \\
\hline & & & & & \\
\hline & & & & & \\
\hline & & & & & \\
\hline & & & & & \\
\hline & & & & & \\
\hline & & & & & \\
\hline & & & & & \\
\hline & & & & & \\
\hline & & & & & \\
\hline Receitas Totais & & & Despesas Totais & & \\
\hline & & PLANEJ & DO & EXEC & TADO \\
\hline
\end{tabular}

Fonte: Tabela elaborada pelo Autor 
Observa-se que, no controle da produção, somente são registrados aqueles gastos, efetivamente ocorridos, ou seja, aquilo que foi, realmente utilizado, no processo de produção. Se, por exemplo, compra-se uma determinada quantidade de adubo para ser utilizada, numa determinada atividade, e não se utiliza todo o adubo, devemos registrar, como custo, somente o valor correspondente à quantidade realmente consumida, na adubação.

Cabe ressaltar que se parte da produção é utilizada para consumo próprio dos associados ou, ainda, para a alimentação de animais, esta parcela também deve ser considerada como receita, pois o produto existiu e, se não fosse consumido, teria sido comercializado.

Tabela 32 - Apuração do resultado geral da Associação

AANRA - ASSOCIAÇÃO DOS AGRICULTORES DE NOVA RONDA ALTA
RESULTADO GERAL DA ASSOCIAÇÃO - EXERCÍCIO:

A) RECEITAS/ATIVIDADE

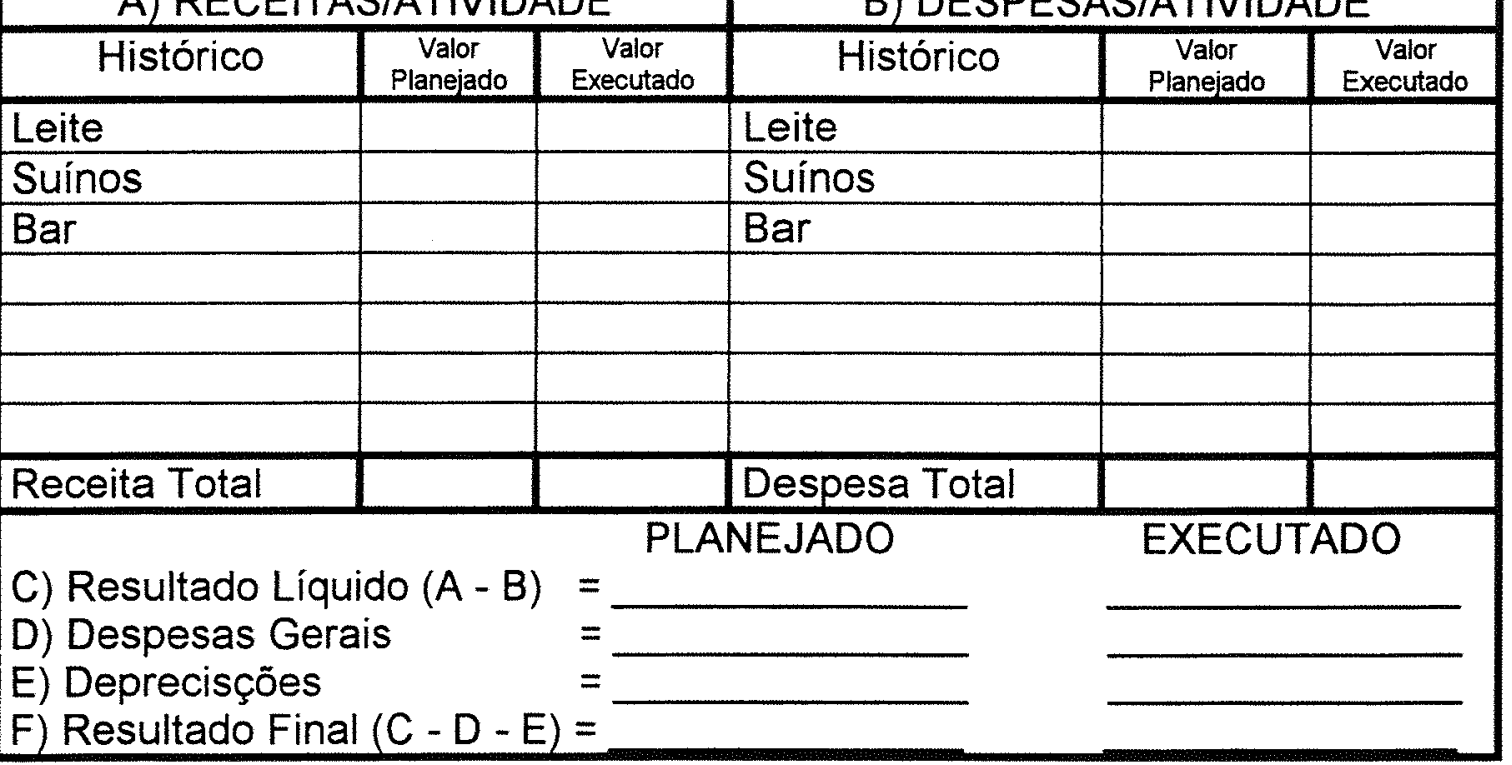

Fonte: Tabela elaborada pelo Autor

Preenchidas as tabelas de controle da produção, com a apuração do resultado líquido por atividade, tem-se condições de elaborar uma tabela resumo para todas as atividades agrupadas e que representa o resultado 
geral da Associação. A tabela 32 pode ser utilizada para essa finalidade. Para o seu preenchimento, basta que se transfiram os valores totais das receitas e das despesas, de cada atividade, e que se incluam, ainda, os valores das depreciações e das despesas gerais da Associação.

Finalmente, ressalta-se a importância do PCP, na medida em que se constitui, de fato, num instrumento extremamente útil ao processo decisório da Associação, na medida em que fornece informações precisas e detalhadas, sobre as diferentes atividades desenvolvidas. Por outro lado, produz um conjunto de informações úteis e que podem ser, através da sua evolução, comparadas com índices técnicos recomendados pelos órgãos de assistência técnica.

Resumindo, pode-se afirmar que, com o passar do tempo, o sistema de Planejamento e o Controle da Produção se constituirá num banco de dados, contendo informações confiáveis sobre o processo de PCP da própria Associação. Este banco de dados possibilitará aos dirigentes da Associação uma tomada de decisão, eficiente e eficaz, a respeito do processo de produção da entidade. Por outro lado, a constante comparação entre os dados planejados e o controle assume a função de monitoramento constante, na medida em que permite que possiveis erros sejam solucionados tão logo ocorra a sua identificação. Em suma, precisamos ter claro que o PCP constitui-se num instrumento útil para o sucesso do empreendimento associativo, pois viabiliza a gestão racional, eficiente e eficaz dos recursos coletivos. 


\section{AS CONTRIBUIÇÕES DO MODELO DE PCP PARA AS ASSOCIAÇÕES DE PRODUÇÃO COLETIVA}

Esta parte do trabalho tem por objetivo discutir, num primeiro momento, o modelo de Planejamento e Controle da Produção, sugerido para a Associação de Agricultores de Nova Ronda Alta. Num segundo momento, serão discutidas algumas contribuições do modelo para as associações de produção coletiva.

\subsection{O modelo de Planejamento e Controle da Produção na} Associação dos Agricultores de Nova Ronda Alta

Certamente 0 modelo de PCP proposto, a partir das informações e dados da AANRA, precisa de um tempo maior para a sua completa avaliação, pois os próprios associados e a associação necessitam de um período maior para o seu entendimento e sua plena implantação. Mas, mesmo com esta dificuldade, pode-se elencar alguns elementos que são importantes para o aperfeiçoamento do modelo.

A primeira questão que necessita ser colocada é que a adoção deste, ou de qualquer outro modelo de PCP, irá ocorrer, somente se a própria associação sentir a necessidade de usar alguns instrumentos, como forma de subsidiar, com informações relevantes, o seu processo de tomada de decisão. Quanto a isto, conforme várias colocações dos Associados da AANRA, pode-se afirmar que, atualmente, esta é uma das maiores preocupações da Associação. Porém, mesmo assim, verificam-se algumas dificuldades para a adoção do modelo.

A primeira dificuldade diz respeito aos limites que os próprios associados apresentam, na medida em que não estão habituados a registrar e anotar, regularmente, os atos e os efeitos destes, no seu dia a dia. A falta da prática, diária e regular, de anotações, produz uma série de dificuldades para os 
associados. Sabe-se que a primeira condição necessária, para que o modelo apresente os resultados esperados, constitui-se na necessidade do registro de todos os fatos relacionados ao planejamento e ao controle da produção das atividades desenvolvidas.

Isto pode decorrer pelo fato da associação, como entidade jurídica, contratar os serviços de um profissional que não está preocupado, pelo menos neste momento, com a análise e a interpretação dos resultados apresentados. Estes resultados, de certa forma, poderiam ser úteis ao processo decisório, porém, raramente são utilizados porque os associados não têm um pleno conhecimento da técnica contábil, bem como não conseguem tirar conclusões, pois não dominam estes conceitos, pela falta de conhecimentos.

A segunda dificuldade diz respeito à possivel confusão que pode ocorrer, em função da quantidade e das diferentes formas de registro, nos diferentes instrumentos oferecidos, para o controle. e o planejamento da produção. Esta dificuldade requer, por parte dos associados, uma certa dose de persistência e de treinamento, para que, de fato, os dados anotados e registrados no PCP possam ser usados como informações úteis no processo de gerenciamento da Associação.

Para superar este problema, a introdução dos diferentes instrumentos de PCP pode ser de forma lenta e gradual, iniciando-se, geralmente, na atividade mais importante da associação para, apenas num segundo momento, quando os associados dominarem melhor o modelo, serem introduzidas nas demais atividades.

Outra questão que necessita ser trabalhada na Associação é o fato de que o modelo de PCP não deve ser entendido como apenas mais uma tarefa a ser cumprida, ou apenas mais uma atividade diária. Deve ser entendida sim, como uma forma de identificar os possíveis problemas relacionados ao 
processo de produção e, além disto, uma forma mais eficiente de enfrentamento dos problemas, bem como de viabilizar o processo decisório

Há de se considerar, no entanto, que a assimilação, por parte dos associados, do processo de planejamento e de controle da produção, não deve ser entendida como uma simples transmissão de conteúdos específicos, mas de conteúdos que se referem ao processo produtivo desenvolvido pela Associação, fazendo com que os associados utilizem os novos conhecimentos a serviço da ação e da solução dos problemas.

Assim, a formação dos agricultores, para que possam utilizar - instrumental de planejamento de controle da produção das atividades desenvolvidas, faz com que a busca de soluções e de novos conhecimentos aconteçam, a partir da avaliação e da identificação de problemas relacionados às suas atividades. Portanto, este processo de aprendizagem e assimilação do modelo não deve ser entendido como um ritual abstrato, acadêmico e elitista, mas se insere na própria vida e prática dos agricultores.

\subsection{O modelo de PCP e o processo de tomada de decisão nas} Associações de produção coletiva

A atual situação econômica brasileira demonstra que o modelo de desenvolvimento adotado não superou os problemas relativos à pobreza rural, na medida em que, verifica-se a manutenção e o agravamento da crise econômica. $O$ agravamento da crise traz consigo uma série de problemas aos agricultores, fazendo com que, a cada dia, o processo de tomada de decisão seja mais importante e fundamental para a manutenção desta categoria no processo de produção.

Neste sentido, várias ações estão sendo implementadas para auxiliar na superação dos graves problemas que afetam, principalmente, os pequenos e médios agricultores. Neste campo, as associações de pequenos 
agricultores surgem como uma das alternativas encontradas. Assim, o desafio para o momento parece ser o de equacionar o discurso crítico com a construção de instrumentos de ação sobre a realidade. Dentre as ações, a adoção, por parte destes agricultores, de alguns instrumentos gerenciais, pode ser de fundamental importância para melhorar a eficiência, a eficácia e a racionalidade do processo de tomada de decisão.

Entre estes instrumentos o planejamento e o controle da produção, podem ser entendidos como fundamentais para o correto gerenciamento da associação. LIMA et al. (1995, p.154), esclarecem que "o atual processo de produção agrícola caracteriza-se pela dinâmica com que evoluem e se modificam as bases técnicas de produção. Os agricultores que dispõem de uma melhor formação têm conseguido acompanhar $e$ apropriar-se dessas modificações; da mesma forma, têm tido acesso a um maior e renomeado número de informações, gerenciando, conseqüentemente, com maior eficácia, a sua entidade de produção".

O modelo de PCP procura, justamente, produzir um conjunto de informações acerca da unidade de produção, bem como sobre as sua atividades, com vistas a um eficiente, eficaz e racional processo decisório. Por outro lado, a partir de um conjunto de dados, sobre a própria associação, os quais se apresentam de forma segura, confiável e sobretudo real apresentandose, quando bem trabalhados, como um eficiente sistema de informações gerenciais.

Um dos principais pontos que deve ser observado, quando da implantação do modelo, diz respeito ao processo de tomada de decisão, na Associação. As informações produzidas pelo modelo, necessariamente, deverão subsidiar o processo decisório. Este modelo deverá, ainda, produzir informaçōes eficientes e eficazes e que auxiliem a direção a tomar decisões, também eficientes e eficazes. 
Assim, o modelo de PCP proposto tem como principal característica a organização de toda a documentação, principalmente a interna, utilizada como suporte ao processo de tomada de decisão. Este processo, por outro lado, facilita as negociações internas e externas pois produz informações próprias sobre as atividades desenvolvidas pela associação.

Este modelo proposto deverá auxiliar a diretoria da associação, bem como aos demais associados, nas discussões sobre o processo gerencial da associação. Neste sentido, as informações produzidas deverão, internamente, na associação, aumentar a produtividade dos fatores de produção disponiveis e utilizados na execução das atividades. Externamente, estas informações deverão ser úteis, pois possibilitarão uma melhor inserção da entidade no mercado local e regional que se apresenta, cada vez mais competitivo. Isto será possível porque o modelo de PCP permite obter, com relativa facilidade, os custos de produção e os resultados das atividades. 


\section{CONCLUSÕĖS}

O momento de crise por que passa a economia brasileira exige a busca constante de soluções que possam dar uma resposta aos principais problemas. Estas respostas, necessariamente, devem levar em consideração a racionalidade, a eficiência e a eficácia das ações, na medida em que, dentro do panorama econômico atual, passam a ser elementos fundamentais, para o sucesso de qualquer empreendimento.

Assim, na agricultura, a busca constante de alternativas, que possam manter os pequenos agricultores nos seus processos produtivos, passa a ser a primeira questão que necessita ser colocada. Neste campo a coletivização do processo produtivo surge com uma das melhores respostas, na medida em que se constitui na forma mais abrangente das tentativas de atenuar e responder aos sucessivos problemas, causados por um conjunto de políticas, que tendem a marginalizá-los do circuito produtivo e econômico e das mudanças sociais. Uma alternativa de correção é a chamada Associação de Produção Coletiva.

As Associações de Produção Coletiva se constituem em entidades que agrupam um certo número de agricultores que têm objetivos comuns, com a finalidade de resolverem os seus problemas, coletivamente. A característica básica desta forma de organização da produção é a coletivização dos fatores de produção disponiveis.

O que se observa é que a Associação, na medida em que amplia as possibilidades de escolha, também produz uma série de limitações e de problemas, para o conjunto dos Associados. O simples fato de induzir os indivíduos ao raciocínio coletivo que nem sempre coincide com 0 individual, produz um conjunto de dificuldades, no âmbito do processo decisório da Associação. A correta administração destes e dos outros problemas, com certeza 
determinará o sucesso ou 0 insucesso desta forma de organização. Assim, reforçamos que o processo de tomada de decisão, na Associação, passa a ser um elemento importante, uma vez que ele se constitui numa resposta concreta aos principais problemas.

O processo de tomada de decisão se constitui na utilização de um conjunto de princípios e técnicas administrativas, com o objetivo fundamental de solucionar os problemas enfrentados, bem como obter alternativas que melhorem a situação econômica, financeira, técnica, política e social na Associação. Assim, o processo de tomada de decisão nada mais é do que a execução do processo administrativo.

Para o sucesso do empreendimento associativo, é de fundamental importância a correta gestão dos aspectos econômicos, financeiros e políticos. Segundo a experiência, é no plano da gestão econômico-financeira e técnica, no que tange à implantação de princípios e instrumentos adequados às suas necessidades, à sua concepção político-pedagógica e às suas escalas operacionais, que se situa, claramente, um limite para a consolidação destas Associações.

Em função da natureza destas Associações, o Planejamento e o Controle da Produção (PCP) constitui um instrumento imprescindível para o processo decisório, na medida em que fornece um conjunto de dados e informações atuais, sobre o comportamento das atividades desenvolvidas na entidade.

Especificamente na AANRA - Associação dos Agricultores de Nova Ronda Alta, percebe-se que, após 12 anos, com a desistência de parte significativa dos Associados, passou-se a dar importância para o PCP, como base para o processo de tomada de decisão. Isto ocorre em função de uma 
conscientização e da necessidade de utilizar um conjunto de dados e informações, a respeito das suas atividades.

Em função disto, a Associação passou a procurar e a criar um conjunto de mecanismos próprios de planejamento e controle das suas produções. Esta necessidade fica mais clara, na medida em que as Associações, com o passar do tempo, estão se constituindo numa alternativa para os pequenos agricultores, no sentido da sua manutenção no processo de produção e como forma de melhorar e até de viabilizar a sua permanência no mercado, que se apresenta, nos últimos anos, cada vez mais concorrencial.

Assim, observa-se que a Associação, neste momento, apresenta uma preocupação básica com a otimização no uso dos recursos e fatores de produção disponíveis. Mesmo assim, podemos afirmar que estas preocupações ainda são poucas, na medida em que, na prática, o conjunto de atitudes em relação ao processo administrativo $e$, especificamente os relacionados com o Planejamento e o Controle da Produção, são extremamente tímidos, existindo, na prática, apenas um instrumental na atividade leiteira e de produção de suínos.

Mesmo nestas atividades, a introdução de instrumentos de planejamento e de controle ocorreu em função do acompanhamento de Técnicos. Nas demais atividades, praticamente inexistem estes instrumentos. A experiência tem mostrado que, geralmente, os resultados positivos de uma atividade são anulados por descuidos das demais atividades. Isto significa dizer que as demais atividades, mesmo não produzindo grandes resultados, podem e devem, também, ser gerenciadas, através de instrumentos de planejamento e de controle para que a Associação, como um todo, produza bons resultados e que os objetivos sejam alcançados. 
A partir deste pressuposto, o Planejamento e o Controle da Produção podem, perfeitamente, racionalizar o processo de produção, bem como viabilizar a competitividade da Associação, no mercado, seja local ou regional, o qual apresenta características próprias, porém, como os demais, exige, a cada dia um maior esforço, em termos de qualidade e produtividade física e financeira.

Destaca-se o fato de que, hoje, existe por parte dos Associados, a exigência de um melhor planejamento e de um maior controle das atividades desenvolvidas pois, parecem estar sentindo a necessidade e estão preocupados com o conjunto da Associação, inclusive com a estrutura física de produção. Salienta-se que o mal gerenciamento da estrutura física de produção, em muitos casos, é o responsável direto pela exclusão do produtor do seu processo de produção, na medida em que se preocupa apenas com a produção física.

$O$ que se percebe, a partir das colocações dos Associados da AANRA, sobre a importância e utilidade do PCP, é que esta atividade ainda é pouco desenvolvida, na Associação, na medida em que não existe uma prática ordenada. Em relação ao Planejamento, observa-se que existe apenas um conjunto de discussões a respeito das atividades desenvolvidas, não havendo, contudo, um levantamento e análise sistemática de dados e informações que possam ser utilizados neste processo.

Nas atividades nas quais existem instrumentos de controle, estes se constituem, na verdade, nas formas utilizadas pelos técnicos, para a obtenção de índices zootécnicos de produtividade física dos animais analisados, não apresentando, portanto, muitas informações para o entendimento dos próprios Associados da AANRA. Nas demais atividades, os instrumentos de controle praticamente não existem. A Associação possui apenas algumas anotações, em termos de valores financeiros, como por exemplo, os investimentos mais significativos realizados nas atividades. 
Faltam, na verdade, instrumentos mais sistematizados a respeito de toda a evolução técnica, física, financeira e econômica e os próprios Associados admitem a falta de um controle mais rígido nas demais atividades. Voltamos a ressaltar que isto já se constitui numa das preocupações básicas, atuais, da Associação, pois os agricultores afirmam que estão bem cientes destas necessidades.

O modelo de PCP apresentado pode ser, na medida em que for implementado na Associação, melhorado pelos próprios usuários, no sentido de fornecer, além destas, outras informações valiosas a respeito da Entidade. A sua implantação, porém, não necessita ocorrer em um único momento, podendo, para tanto, a Associação implementar aqueles instrumentos de Planejamento e de Controle da Produção naquelas atividades mais problemáticas e, somente num segundo momento, introduzir todos os modelos recomendados.

Destaca-se, também, que a adoção deste ou de qualquer outro modelo de PCP, por parte da Associação e dos Associados, certamente provocará uma série de problemas para a própria AANRA, na medida em que não existe, neste momento, uma prática e um hábito consolidado de anotações e de registros das atividades diárias dos componentes da Associação. Isto, em outros termos, significa dizer que, para a plena utilização dos instrumentos de planejamento e de controle da produção, uma série de barreiras de ordem pessoal, social, cultural e de conhecimentos deverão ser bem tratados e eliminados, principalmente pela diretoria da Associação.

A diretoria, necessariamente, deverá trabalhar alguns aspectos, junto aos Associados, para que estes assumam os instrumentos de planejamento e de controle, como sendo vitais para o gerenciamento racional, eficiente e eficaz da Associação, bem como para a própria sobrevivência da AANRA e das outras Associações de produção coletiva que venham a utilizar os instrumentos aqui propostos. 
Concluindo, infere-se que o Produtor e a Associação devem sentir a necessidade do Planejamento e do Controle da Produção (PCP) pois, sem esta exigência, os instrumentos de gestão certamente não produzirão as informações necessárias ao correto processo de decisão na Entidade. Neste momento, é exatamente o que a Associação sente, a necessidade de planejar e de controlar a produção para obter melhores resultados, como forma de viabilizar a sua permanência no processo produtivo, e como forma de sobrevivência dos Associados.

Uma questão final que deve ser abordada, é o fato do processo de gerenciamento das Associações, baseado em dados e informações produzidos pelos seus próprios processos de PCP, ser adotado e executado pelos próprios envolvidos, estabelecendo uma maior motivação e mobilização do grupo viabilizando o processo de produção do conjunto da Associação. Isto significa dizer, em outros termos, que a própria eficiência e eficácia da Associação depende, fundamentalmente, da eficiência e da eficácia deste sistema, na medida em que ele viabiliza um aumento da produtividade e da racionalidade no uso dos recursos e dos fatores de produção necessários para a execução das atividades. 
REFERÊNCIAS BIBLIOGRÁFICAS

ADANT, P. Formação de pequenos e médios agricultores para a gerência de empresas agricolas. Brasilia: EMBRATER, 1987. 26p.

ALVES, Zélia M. Intersecções das análises quantitativas e qualitativas. Anais do XVIII Reunião de Psicologia da Sociedade de Psicologia de Ribeirão Preto. Ribeirão Preto, SP, 1988.

ANUÁRIO ESTATÍSTICO DO BRASIL/Fundação Instituto Brasileiro de Geografia e Estatística. Rio de Janeiro, IBGE, 1992.

BIALOSKORSKI NETO, Sigismundo. \& BIANCO, Jader. Agenda de escrituração rural. São Paulo, Secretaria de Agricultura e Abastecimento/CATI, 1992. 86p.

BIALOSKORSKI NETO, Sigismundo. \& NEVES, Evaristo M. O PCP planejamento e controle da produção - um sistema simplificado para pequenas e médias empresas rurais. Piracicaba, SP. 1993. 56p.

BARROS, Henrique de. Análise e planejamento da exploração agricola. Lisboa, Fundação Calouste Gulbenkian, 1964. 803p.

BASSO, David. Produção familiar e desenvolvimento agrário. ljuí, RS.: UNIJUÏ/Departamento de Economia e Contabilidade, 1993. 44p. (Textos para discussão, 12)

BASSO, Irani. Contabilidade agrícola. ljui-RS. 1975. 36p. (mimeo)

BASSO, Nilvo. Prática administrativa em uma associação de pequenos agricultores no Rio Grande do Sul. [Lavras]. Dissertação (mestrado) Escola Superior de Agricultura de Lavras, 1992. 75p. 
BORI, Carolina M. et all. Desempenho de professores universitários no levantamento e caracterização de problemas de ensino: descrição de um procedimento. Anais do VIII Encontro Anual de Psicologia da Sociedade de Psicologia de Ribeirão Preto, SP, 1978. 1020p

CENSO AGROPECUÁRIO/Fundação Instituto Brasileiro de Geografia e Estatística. Rio de Janeiro, IBGE, 1960-80.

CHIAVENATO, Idalberto. Introdução à teoria da administração. São Paulo, McGraw-Hill do Brasil, 1979. 562p.

CORDONNIER, P. et al. Economia de la empresa agrária. Madrid, Ediciones mundi-prensa, 1973. 506p.

CORTINA, Nelson. Planejamento em empresas rurais em Santa Catarina. Piracicaba, SP. 1992. 112p (Mestrado - Escola Superior de Agricultura "Luiz de Queiroz"- ESALQ/USP)

DUDERMEL, T. Brésil Meridional, les enjeux d'une agriculture en crise: capitalistes et paysans du Nort-ouest du Rio Grande do Sul face aux bouleversements economiques. [Paris]. Tese (doutorado) - Institut National Agronomique Paris-Grignon, 1990.

FLECK, Luiz Fernando. Versão brasileira do manual de gestão prática de Fernad Vicent. Rio de Janeiro, AS-PTA, 1992. 32p

FRANCO, Hilário. Contabilidade comercial. São Paulo, Atlas, 1986. 294p.

GRIFFITHS, Daniel E.. Teoria da administração escolar. São Paulo, Cia Editora Nacional, 1976. 129p.

HAGETTE, T. M. F.. Metodologias qualitativas na sociologia. Petrópolis, vozes, $1965.163 p$. 
HARDY, Cyntia. Models of decision making in a canadian university. In: REUNIÃO ANUAL DA ASSOCIAÇÃO NACIONAL DE PÓS-GRADUAÇÃO EM ADMINISTRAÇÃO. Rio de Janeiro, 1987. 140p.

HOFFMANN, Rodolfo. Crise econômica e pobreza no Brasil no período de 1979-90. Relatório de pesquisa. ESALQ/USP/DESR. São Paulo, 1992. 47p.

HOFFMANN, Rodolfo. et al. Administração da empresa agrícola. São Paulo, Pioneiro, 1981. 325p.

HOFFMANN, Rodolfo. Vinte anos de desigualdade e pobreza na agricultura brasileira. In: Revista de Economia e Sociologia Rural. Brasília, v.30, n², p.97-113, abr/jun. 1992

HOLZ, Hélio. A comparação de grupo como instrumento de administração rural nas pequenas exp/orações agricolas. In: EMBRATER/COPER. Coletânea de trabalhos sobra administração rural é adoção de tecnologias. Brasilia-DF., EMBRATER, 1986. 82p

IUDÍCIBUS, Sérgio de. Contabilidade gerencial. São Paulo, Atlas, 1987. 308p.

IUDÍCIBUS, Sérgio de. Teoria da contabilidade. São Paulo, Atlas, 1987. 350p.

JACINTHO, Eduardo. Contabilidae: modernas técnicas e informática. São Paulo, Brasiliense, v.4, 1985. 319p.

KELM, Martinho. Controle financeiro de associações. Rio de Janeiro, AS-PTA, 1992. 56p.

KERLINGER, Fred N.. Metodologia da pesquisa em ciências sociais. São Paulo, EPU/EDUSP/INEP, 1980. 378p.

KWASNICKA, Eunice L.. Introdução à administração. São Paulo, Atlas, 1990. $243 p$. 
LIMA, Arlindo Jesus $P$. de. et al. Administração de unidades de produção familiar: modalidades de trabalhos com agricultores. ljuí, RS, Editora UNIJUÍ, 1995. 175p.

Arlindo J. P. de. A natureza da prática administrativa na produção familiar: um estudo na comunidade de Santana, municipio de Tapejara (RS). [Lavras]. Dissertação (mestrado) - Escola Superior de Agricultura de Lavras, 1992. 124p.

MARTINS, J. de Souza. Os camponeses e a política no Brasil. Rio de Janeiro, Vozes, 1981. 186p.

MENDEZ, Maria Júlia \& GÓMEZ, Jésus E. T. Guia para gestão em áreas reformadas. Recife, INCRA/PNUD/SUDENE, 1989. 215p.

MONTEIRO, José de Anchieta. A geração de tecnologia de agrícola e a ação de grupos de interesse. São Paulo, FIPE/EPAMIG; 1985. 170p.

MOTTA, Fernando C. P \& PEREIRA, Luiz C. B. Introdução à organização burocrática. São Paulo. Brasiliense, 1986. 132p

MUENCHEN, José Valdemir. Análise financeira e econômica de associações. Rio de Janeiro, AS-PTA, 1992. 34p.

MURCIA, Héctor. Administracion de empresas associativas de producion agropecuária. San José, Costa Rica, IICA, 1985. 232p.

NEVES, E. M. et alii. A economia de mercado e planejamento da empresa agrícola: desafios para a década de 90. Revista ADEALQ, Piracicaba, (14):15-9, 1991.

UNIJUII. Programa da Administração Rural (PAR). Relatórios de trabalho. ljuiRS. $1981-90$ 
PÉRES, Fernando C. \& NORONHA, José F. de. O impacto da análise de sistemas na agricultura: o caso da administração e da economia rural. Piracicaba-SP., ESALQ/USP/DESR. 1985.15p.

PINTO, João B. et al. Participação: rito ou prática social. IN: Revista CONTEXTO E EDUCAÇĀO. Livraria UNIJUí editora. ljuí, RS, 1986. 113p.

REASON Peter \& ROWAN, John. Human inquiry: a sourcebook of new paradigm research. Chinchester:John Wiles \& Sons, 1981. 620p.

SILVA NETO, B. Les potentialités de l'agriculture familiale dans une région de grandes domaines d'élevage extensif: contribution - la réflexion sur la réforme agrarie dans l'Etat du Rio Grande do Sul (Brésil). [Paris]. Tese (doutorado) - Institut National Agronomique Paris-Grignon, 1994.

SIMĀO, Lívia M. Interação pesquisador-sujeito: a perspectiva de ação social na construção do conhecimento. Ciência e Cultura, 41(12):1195-1202, 1989.

SOUZA, Nali de Jesus. Notas sobre metodologia de pesquisa. Porto Alegre, IEPE/UFRGS, 1984 165p.

SOUZA, Ricardo de. et al. A administração da fazenda. Rio de Janeiro, Globo, 1989. 211p.

THIOLLENT, Michel. Metodologia da pesquisa-ação. Cortez Editora. São Paulo, 1986. 107p.

TUNG, N. H. O Controle financeiro para pequenas empresas agropecuárias brasileiras. São Paulo, Rev. de Administração, v.27, nª1, pg. $61-68$ jan/março 1992. 
TUNG, N. H. Planejamento e controle financeiro das empresas agropecuárias. São Paulo, Ed. Universidade Empresa, 1990, 382 p.

VIEIRA, Marcelo M. F. Características estruturais de organizações coletivas. Anais do XIV Encontro Anual da ANPAD. Vol. 6. Belo Horizonte, MGSP Editores Ltda. 1990. 175p.

ZANELLI, José C. Formação profissional e atividades de trabalho: análise das necessidades identificadas por psicólogos organizacionais. Tese de doutorado. Campinas: Universidade de Campinas, 1992 